\title{
Az inga egyensúlyi helyzeteinek stabilizálása és destabilizálása
}

Doktori értekezés

CSIZMADIA LÁSZLÓ

TÉMAVEZETÔ:

DR. HATVANI LÁSZLÓ

PROFESSOR EMERITUS

MATEMATIKA ÉS SZÁMÍTÁSTUDOMÁNYOK DOKTORI ISKOLA SZEGEDI TUDOMÁNYEGYETEM

TERMÉSZETTUDOMÁNYI ÉS INFORMATIKAI KAR

BOLYAI INTÉZET

SZEGED

2018 


\section{Tartalomjegyzék}

1. Elôszó 1

2. Bevezetés 4

3. A hintázásról $\quad 8$

3.1. Arnold nyomán . . . . . . . . . . . . . . . . . . . . 9

3.1.1. A Floquet-elv . . . . . . . . . . . . . . . 9

3.1.2. A Floquet-elv használata . . . . . . . . . . . . 10

3.2. Elemi úton . . . . . . . . . . . . . . . . . . . 12

3.2.1. Technikai háttér . . . . . . . . . . . . . 13

3.2.2. Periodikus, origóhoz közeledô és origótól távolodó pályák 15

3.2.3. Stabilitási térkép . . . . . . . . . . . . . . . 31

4. Fölsô egyensúlyi helyzet stabilizálása 35

4.1. Levi és Weckesser módszere . . . . . . . . . . . . . . . . . 36

4.2. A Levi-Weckesser módszer kiterjesztése . . . . . . . . . . . . . 38

4.2.1. Aszimmetrikusan rezgetett inga felsố egyensúlyi helyzetének stabilizálhatósága . . . . . . . . . . . . . 38

4.2.2. Eredmények . . . . . . . . . . . . . . . . . 46

5. A fordított inga periodikus mozgásai $\quad 54$

5.1. A vizsgált modell . . . . . . . . . . . . . . . . . 54

5.2. Periodikus pályák konstruálása . . . . . . . . . . . . . 58

5.3. Stabilitás és számítógépes szimulációk . . . . . . . . . . . . . 67

6. Összefoglalás $\quad 75$ 
7. Summary

Köszönetnyilvánítás

83

Irodalomjegyzék 


\section{1. fejezet}

\section{Elôszó}

Az inga szó hallatán többségünk egy rúdon függó nehezékre asszociál, amelyik az alsó „holtpontja", szabatosabban mondva, az alsó egyensúlyi helyzete közelében kis lengéseket végez. Ennek az eszköznek a gyerekek által nagy örömmel használt módozata a hinta, melybe ülve elóbb-utóbb mindegyikük ráérez arra, hogy saját testhelyzetének mozdításával egyre nagyobb és nagyobb lengéseket képes végezni. Ha a súrlódástól eltekintünk és a később pontosításra kerülő lineáris közelítésre fókuszálunk, akkor a hinta mozgását egy

$$
\ddot{x}+f(t) x=0
$$

alakú differenciálegyenlet írja le, ahol $x=x(t)$ a hinta szögkitérése a függőleges iránytól mérve pozitív irányítás szerint, az óramutató járásával ellentétes irányt választva pozitív forgásiránynak, $f(t):[0, \infty) \rightarrow \mathbb{R}$ pedig a hintázó föl-le guggoló mozgását magába foglaló rész. Amennyiben ez az $f$ függvény periodikus, akkor az (1.1) egyenletet Hill-egyenletnek hívjuk, G. W. Hill [21] cikke nyomán. Gyakori, hogy az (1.1)-beli $f$ függvényt speciálisan választják: ha $f(t)=\cos (t)$, akkor Mathieu-egyenletnek [30], ha pedig $f(t)$ egy periodikus lépcsősfüggvény, akkor Meissner-egyenletnek [31] nevezzük az (1.1) egyenletet.

A Hill-egyenletekkel kapcsolatos egyik fó eredmény az úgynevezett oszcillációs tétel [29, 32], mely az adott differenciálegyenlet periodikus megoldásainak eloszlásáról szól. A [10] dolgozatunkban a klasszikus oszcillációs tétel egy speciális esetét tudtuk megadni azáltal, hogy megkonstruáltuk az ott tárgyalt differenciálegyenlet periodikus megoldásait. Az (1.1) típusú egyenlet vizsgálata 
igen aktív volt korábban is és ma is, ezzel kapcsolatos cikkeket találunk B. Van der Poltól [37] C. Simón [6] át egészen M. Leviig [5].

Ugyancsak a könnyed kikapcsolódás eszközeként, elsősorban artista trükként ismert [3], hogy az ingát „fejére állítva" egyensúlyban lehet tartani a fölsó egyensúlyi helyzetében is. Erre több lehetôség kínálkozik: gondoljunk csak az orrán söprüt egyensúlyozó artistára, esetleg az egyre elterjedtebb közlekedési eszközre, a segway-re $[2,36]$. Azt, hogy az inga fölsố egyensúlyi helyzetét a fölfüggesztési pontja alkalmasan választott frekvenciájú és amplitúdójú függóleges irányú rezegtetésével is stabilizálni lehet, elsôként A. Stephenson írta le 1908ban [34, 35]. A fölsố egyensúlyi helyzet körüli mozgásokat leíró egyenletet teljes részleteibe menően 1951-ben megjelent cikkeiben P. L. Kapica vizsgálta [23, 24], és azóta gyakran Kapica-ingaként hivatkoznak erre a jelenségre. A Nobel-díjas Kapica egy olyan matematikai-fizikai iskola tagja volt, melyhez hozzátartozott például L. D. Landau és V. I. Arnold is. Nem meglepô tehát, hogy ốk is foglalkoztak az inga egyensúlyi helyzeteinek stabilitási tulajdonságaival [1, 25]. A már említett J. Moser tanítvány, M. Levi a hintázás problémája mellett szintén több dolgozatában tanulmányozta a fölsố egyensúlyi helyzet stabilizálhatóságát [26, 27, 28]. A [28]-ban Levi és szerzőtársa által elért eredményt az ott közölt módszer további pontosításával sikerült élesítenünk, illetve általánosítanunk a 2014-ben kiadott [9] publikációnkban. Témavezetôm, Hatvani László 1998-ban megjelent [16] cikkében olyan technikát mutat, melyet haszonnal lehet forgatni az inga egyensúlyi helyzeteinek vizsgálatán túl, a már említett periodikus megoldások föltérképezése során is, így a [11] dolgozatunkban sikerült a [10] cikkbeli oszcillációs tétel „fordított" ingára vonatkozó analogonját megadni.

Disszertációm az inga fölsố egyensúlyi helyzetének stabilizálhatóságáról, illetve alsó egyensúlyi helyzetének destabilizálhatóságáról szól, megadva az alkalmasan választott és késóbb részletezésre kerülő paramétertartományokban a stabil és instabil zónákat az azokat elválasztó periodikus megoldásokból álló görbék leírása segítségével. A disszertáció fő eredménye, hogy eleminek mondható vizsgálati eszköz használatával sikerült egy korábban megjelent eredményt élesíteni és általánosítani, illetve elkészíteni az úgynevezett stabilitási térképet a Floquet-elvre épülő, bonyolult számítások használata nélkül. Ez azt is jelenti, hogy a módszer alkalmas mélyebb matematikai ismeretekre támaszkodó elmélet 
használatának áthidalására, segítve annak fokozatos megismerését, elsajátítását. Az értekezés a szerző következô publikációin alapul:

- L. Csizmadia, L. Hatvani, An extension of the Levi-Weckesser method to the stabilization of the inverted pendulum under gravity, Meccanica, 49(2014), 1091-1100.

- L. Csizmadia, L. Hatvani, On a linear model of swinging with a periodic step function coefficient, Acta Sci. Math. (Szeged), 81(2015), 483-502.

- L. Csizmadia, L. Hatvani, On the existence of periodic motions of the excited inverted pendulum by elementary methods (benyújtva). 


\section{2. fejezet}

\section{Bevezetés}

Jól ismert [1, 8], hogy a matematikai inga egy merev, elhanyagolható tömegû, $l$ hosszúságú rúdból és a hozzá rögzített $m$ tömegú tömegpontból áll. Lényeges eleme ennek az egyszerú rendszernek az az úgynevezett holonom kényszer, amit az inga rúdjának nyújthatatlansága jelent: gondolatban helyezzük el az inga fölfüggesztési pontját a Descartes-féle derékszögú koordináta-rendszer origójába, és a tömegpont koordinátái legyenek $x_{1}, x_{2}$. A kényszer matematikai alakja így: $x_{1}^{2}+x_{2}^{2}=l^{2}$. Ez pontosan azt jelenti, hogy a rúd végére rögzített tömegpont egy l sugarú körpályán képes mozgást végezni. Ebból viszont könnyú látni, hogy a rendszer egy szabadsági fokú, hiszen a tömegpont helyzetét minden időpillanatban meg tudjuk mondani, ha megmondjuk, hogy egy jól választott iránnyal legyen ez a függőleges, fölfelé mutató - mekkora szöget $(\psi)$ zár be az inga rúdja. A körülfordulási irányt akkor tekintjük pozitívnak, ha az ellentétes az óra járásának irányával. Ha az ingára a gravitáción kívül - a gravitációs gyorsulást $g$ jelöli - nem hat semmilyen más erô, tehát nincs súrlódás sem, akkor a rendszer Lagrange-függvénye, melyet a kinetikus és potenciális energiák különbségeként kapunk:

$$
L=T-V=\frac{m l^{2}}{2} \dot{\psi^{2}}+m g l \cos \psi, \quad \dot{\psi}:=\frac{d \psi}{d t} .
$$

Ennek segítségével fölírhatjuk az Euler-Lagrange-egyenletet, azaz a mozgásegyenletet:

$$
\frac{d}{d t} \frac{\partial L}{\partial \dot{\psi}}-\frac{\partial L}{\partial \psi}=m l^{2} \ddot{\psi}+m g l \sin \psi=0
$$


Ebból pedig átalakítással nyerjük, hogy

$$
\ddot{\psi}+\frac{g}{l} \sin \psi=0 \quad(-\infty<\psi<\infty) .
$$

Amint az a (2.1) egyenletból látható, a rendszernek két egyensúlyi helyzete van: $\psi \equiv 0(\bmod 2 \pi)$, illetve $\psi \equiv \pi(\bmod 2 \pi)$, amit rendre alsó, illetve fölsố egyensúlyi helyzetnek hívunk. Az A. M. Ljapunov által bevezetett stabilitási fogalmakkal [32] élve azt mondhatjuk, hogy az alsó egyensúlyi helyzet stabil, míg a felső instabil. A nemlineáris egyenletek elsố közelítésben történô stabilitásvizsgálata, melyet először Ljapunov írt le [31], azt jelenti, hogy az eredeti rendszert - szokás perturbált rendszernek nevezni - egy alkalmas, lineáris - perturbálatlan - rendszerrel közelítjük. Jelen esetben ez azt jelenti, hogy az egyensúlyi helyzetek kis környezetében - jelölje ezeket rendre $U_{0}$ és $U_{\pi}$ - a (2.1) egyenletet linearizáljuk. Ha $\psi \in U_{0}$, akkor $\sin \psi \approx \psi$, ha pedig $\psi \in U_{\pi}$, akkor $\sin \psi \approx-\psi+\pi=-(\psi-\pi)$. Átmenetileg legyen $\theta:=\psi-\pi$, vagyis amikor $\psi=\pi$, akkor $\theta=0$. Fölírhatjuk most már az alsó, illetve fölsố egyensúlyi helyzet körüli „,kis" mozgásokat leíró lineáris másodrendú differenciálegyenleteinket:

$$
\ddot{\psi}+\frac{g}{l} \psi=0, \quad \ddot{\theta}-\frac{g}{l} \theta=0 .
$$

A továbbiakban nem fog félreértést okozni, ha a $\theta$ helyett akkor is $\psi$ jelöli az egyenletben szereplő ismeretlent, amikor a fölsô egyensúlyi helyzet körüli mozgásokról beszélünk. Formálisan tehát a (2.2) egyenleteket egyetlen formulával is meg tudjuk adni:

$$
\ddot{\psi} \pm \frac{g}{l} \psi=0
$$

ahol a lineáris tag elójelének értelme a föntiek alapján világos.

A hinta, illetve a Kapica-inga esetében a (2.3) egyenletben a $\psi$ együtthatója nem állandó, hanem egy periodikus függvény. Mi azokat az eseteket vizsgáljuk, amikor ez az együttható egy periodikus lépcsősfüggvény, és egy periódus két lépcsóból áll. A [16] publikációban bevezetett és a [17] publikációban kifejtett módszerrel az ilyen egyenleteket a következőképpen tudjuk vizsgálni. Amint azt késóbb látni fogjuk az általunk vizsgált mozgásegyenleteket formailag az

$$
\ddot{x} \pm a^{2}(t) x=0, \quad a(t):=a_{k}, \text { ha } t_{k-1} \leq t<t_{k} \quad(k \in \mathbb{N})
$$

alakúra tudjuk hozni, ahol $\left\{a_{k}\right\}_{k=1}^{\infty},\left\{t_{k}\right\}_{k=0}^{\infty}$ pozitív számok olyan sorozatai, melyekre $t_{k}<t_{k+1}$ minden $k \in \mathbb{N}$ esetén, $\lim _{k \rightarrow \infty} t_{k}=\infty$, és $t_{0}:=0$. A (2.4) 
egyenletben az elôjel szerepe a (2.3) egyenlet alapján érthetô: amikor a hintázást vizsgáljuk, tehát az alsó egyensúlyi helyzet körüli mozgásokat tárgyaljuk, akkor +, amikor pedig a fordított ingát vizsgáljuk, tehát a fölsố egyensúlyi helyzet körüli mozgásokat tekintjük, akkor az előjel - . Az $x:[0, \infty) \rightarrow \mathbb{R}$ a (2.4) egy megoldása, ha folytonosan differenciálható az $[0, \infty)$ intervallumon, és az $\left.x\right|_{\left[t_{k-1}, t_{k}\right)}$ megszorítása kétszer differenciálható, továbbá kielégíti az egyenletet minden $k \in \mathbb{N}$ esetén. Tekintsük először azt az esetet, amikor a (2.4) egyenlet alakja: $\ddot{x}+a^{2}(t) x=0$. Bevezetve az új $y:=\dot{x} / a_{k}$ állapothatározót a (2.4) egyenlet a

$$
\dot{x}=a_{k} y, \quad \dot{y}=-a_{k} x \quad\left(t_{k-1} \leq t<t_{k}, k \in \mathbb{N}\right) .
$$

2-dimenziós rendszerbe megy át. A (2.4) egyenlet $x=x(t)$ megoldása deriváltjának, $\dot{x}$-nak folytonosságát garantálandó előírjuk a következô feltételeket: $x\left(t_{k}\right)=x\left(t_{k}-0\right), \dot{x}\left(t_{k}\right)=\dot{x}\left(t_{k}-0\right)(k \in \mathbb{N})$, ahol $f(t-0)$ az $f$ függvény bal oldali határértéke a $t$ helyen. Ez a (2.5) rendszerre vetítve a következőket jelenti:

$$
\left\{\begin{array}{l}
\dot{x}=a_{k} y, \quad \dot{y}=-a_{k} x \quad\left(t_{k-1} \leq t<t_{k}\right), \\
x\left(t_{k}\right)=x\left(t_{k}-0\right), \quad y\left(t_{k}\right)=\frac{a_{k}}{a_{k+1}} y\left(t_{k}-0\right) \quad(k \in \mathbb{N}) .
\end{array}\right.
$$

Azt kaptuk tehát, hogy a (2.4) egyenlet ekvivalens egy olyan dinamikus rendszerrel, melynek során a $t=t_{k},(k \in \mathbb{N})$ csatlakozási pontokban egy impulzív effektus történik. A (2.6) rendszer viselkedését a fázistéren, azaz az $(x, y)$ síkon is le tudjuk írni. Legyen $x_{0}, y_{0}$ egy adott pont a fázistéren. Ekkor a (2.6) hatására a (2.5) $x\left(t_{0}\right)=x_{0}, y\left(t_{0}\right)=y_{0}$ kezdetiérték-feltételnek eleget tevô megoldásnak megfelelôen a fázispont egy trajektórián mozog, amíg $t_{0} \leq t<t_{1}$, majd $t=t_{1}$-ben megtörténik az elsô impulzív hatás, ami egy $y$-tengellyel párhuzamos, $a_{1} / a_{2}$ mértékú kontrakció vagy dilatáció, s így elérkezik az $\left(x_{1}, y_{1}\right)$ ponttal reprezentált állapotba. Ezután újra a dinamika folytonos komponense hat a fázispontra, vagyis az egy fázisgörbén mozog a $t_{1} \leq t<t_{2}$ intervallumon, a $t=t_{2}$-ben újra egy ,ugrás", azaz egy $a_{2} / a_{3}$ mértékủ kontrakció vagy dilatáció történik, és bekerül az $\left(x_{2}, y_{2}\right)$ állapotba. Innen a folyamat az eddigieknek megfelelően ismétlódik az idők végezetéig. Az említett trajektória, fázisgörbe alakja a (2.5) egyenletrendszerból kapható. Vegyük észre ugyanis, hogy a

$$
H_{e}(x, y):=x^{2}+y^{2}
$$


mennyiség a (2.5) rendszer egy elsó integrálja. Ez azt jelenti, hogy a fázisgörbék origó középpontú, egymással koncentrikus körívek. Azt mondjuk, hogy a (2.6) rendszer folytonos része „elliptikus (közönséges) forgatás". Hasonlóképpen járunk el, amikor a (2.4) egyenlet alakja: $\ddot{x}-a^{2}(t) x=0$. Az $y=\dot{x} / a_{k}$ bevezetése azt eredményezi, hogy a (2.4) egyenlet a

$$
\dot{x}=a_{k} y, \quad \dot{y}=a_{k} x \quad\left(t_{k-1} \leq t<t_{k}, k \in \mathbb{N}\right) .
$$

rendszerbe transzformálódik. Ennek a rendszernek a

$$
H_{h}(x, y):=x^{2}-y^{2}
$$

egy elsố integrálja. Ez azt jelenti, hogy ebben az esetben a fázisgörbék hiperbolák. A megfelelő impulzív dinamikus rendszer alakja tehát

$$
\left\{\begin{array}{l}
\dot{x}=a_{k} y, \quad \dot{y}=a_{k} x \quad\left(t_{k-1} \leq t<t_{k}\right), \\
x\left(t_{k}\right)=x\left(t_{k}-0\right), \quad y\left(t_{k}\right)=\frac{a_{k}}{a_{k+1}} y\left(t_{k}-0\right) \quad(k \in \mathbb{N}) .
\end{array}\right.
$$

A föntiek alapján azt mondjuk, hogy (2.9) rendszer folytonos komponense „hiperbolikus forgatás", lásd a 2.1 ábrát. Tehát ebben az esetben a fázispont hiperbolákon mozog és a $t=t_{k},(k \in \mathbb{N})$ csatlakozási pontokban $y$-tengely irányú kontrakció/dilatáció hat rá.

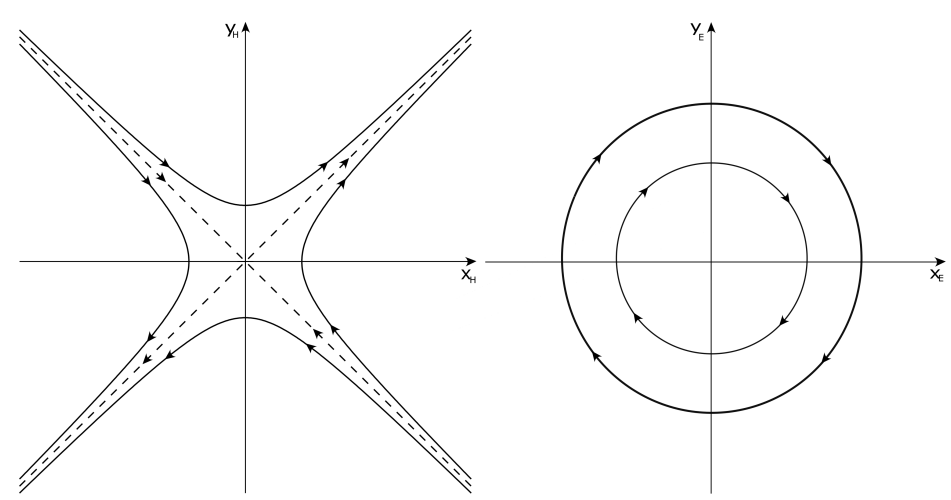

2.1. ábra. Hiperbolikus és elliptikus forgás 


\section{3. fejezet}

\section{A hintázásról}

A hinta egy olyan inga, melynek hossza az időben változik: a hintázó hol guggoló, hol kinyújtott testhelyzetet vesz föl, azaz testének tömegközéppontját hol följebb, hol lejjebb helyezve igyekszik a hinta alsó egyensúlyi helyzetét destabilizálni. Ennek megfelelóen a hintázás matematikai modellje a Bevezetésben ismertetett (2.3) egyenlet módosításával kapható. Arnold [1] mưvében leírtak szerint, tegyük föl, hogy a hintázó hatására a hinta hossza periodikusan változik, azaz tekintsük az

$$
\begin{aligned}
\ddot{x}+a^{2}(t) x & =0, \\
a(t) & :=\left\{\begin{aligned}
a_{1} & :=\sqrt{\frac{g}{l-\varepsilon}}, \text { ha } \quad 2 k T \leq t<(2 k+1) T, \\
a_{2}: & : \sqrt{\frac{g}{l+\varepsilon}}, \text { ha } \quad(2 k+1) T \leq t<(2 k+2) T, \quad(k=0,1, \ldots)
\end{aligned}\right.
\end{aligned}
$$

egyenletet, ahol a (2.3)-tôl eltérốn $\psi$ helyett $x$ jelöli az inga rúdjának a függólegessel bezárt szögét, továbbá $\varepsilon>0$ az a paraméter, melynek segítségével a hintázás intenzitását jellemezzük, $T>0$ a hinta hosszváltozásának fél periódusa. A hintázás problémáját a következóképpen lehet megfogalmazni: határozzuk meg a $(T, \varepsilon)$ paramétersík instabil tartományát, vagyis azon részét, ahonnan választott paraméterértékekkel a (3.1) egyenlet $x=0$ megoldása instabil. 


\subsection{Arnold nyomán}

\subsubsection{A Floquet-elv}

Egy periodikus együtthatós differenciálegyenlet-rendszer megoldásának stabilitásvizsgálata rendszerint azt a módszert követi, melyet elôször Floquet írt le [8], és egy olyan koordináta-transzformációt jelent, mellyel a változó együtthatós rendszer konstans együtthatójúvá tehetô. Ennek a konstans együtthatómátrixnak könnyedén számíthatóak a sajátértékei, melyekre szükség van az analízis során. Tekintsük tehát az

$$
\dot{x}=A(t) x, \quad x \in \mathbb{R}^{n}
$$

egyenletrendszert, ahol a $t \mapsto A(t) 2 T$-periodikus mátrixfüggvény, $t \in \mathbb{R}$. A (3.2) rendszer alaprendszerének kanonikus előállítását adja meg a Floquet-tétel.

3.1. Tétel. Legyen $\Phi(t)$ a (3.2) egy alapmátrixa. Ekkor létezik olyan $2 T$-periodikus $t \mapsto P(t)$ komplex mátrixfüggvény és létezik egy olyan $B$ konstans mátrix, hogy bármely $t \in \mathbb{R}$ esetén

$$
\Phi(t)=P(t) e^{t B}
$$

3.2. Megjegyzés. Elóbbi tétel a valós esetre vonatkoztatva azt mondja, hogy van olyan valós $R$ konstans mátrix és olyan $4 T$-periodikus $t \mapsto Q(t)$ valós mátrixfüggvény, hogy minden $t \in \mathbb{R}$ esetén $\Phi(t)=Q(t) e^{t R}$.

Ha a $\Phi(t)$ alaprendszert úgy választjuk, hogy $\Phi(0)=E$, ahol $E$ az egységmátrix, akkor az $M=\Phi(T)=e^{T B}$ mátrixot monodrómiának, monodrómia-mátrixnak nevezzük. A monodrómia-mátrix sajátértékei a rendszer úgynevezett karakterisztikus tényezői. A $\mu$ komplex számot karakterisztikus kitevônek (Floquetkitevơnek) hívjuk, ha $\lambda$ karakterisztikus tényezó és $e^{\mu T}=\lambda$. Jól ismert [32], hogy egy konstans együtthatós lineáris rendszer megoldásainak stabilitása azon múlik, hogy az együtthatómátrix sajátértékei hogyan helyezkednek el a komplex síkon.

A következókben követjük Arnold [1] jegyzetében található gondolatot, mely a (3.2) rendszer úgynevezett erôs stabilitását adja meg.

A (3.2) lineáris rendszer stabil, ha minden megoldása korlátos, azaz van olyan $c>0$ szám, hogy $|\Phi(t)|<c$ bármely $t \in(0, \infty)$ esetén, ahol $|$.$| a mátrix$ normáját jelenti. 
3.3. Definíció. $A(3.2)$ egyenlet erôsen stabil, ha van olyan $\varepsilon>0$, hogy az $\dot{x}=$ $B(t) x, B(t+T) \equiv B(t)$ rendszer stabil föltéve, hogy $|B(t)-A(t)|<\varepsilon(t \in \mathbb{R})$.

3.4. Definíció. Egy $M$ mátrix, melyre $\operatorname{det} M=1$ stabil, ha minden $k \in \mathbb{Z}$ esetén van olyan $c>0$ szám, hogy $\left|M^{k}\right|<c$. Az $M$ mátrix erósen stabil, ha minden hozzá közeli $N$ mátrix, melyre $\operatorname{det} N=1$, stabil.

Az $M$ és $N$ mátrixok távolsága a különbségük normája. Bizonyítás nélkül említjük a következő tételt.

3.5. Tétel. A (3.2) egyenlet akkor és csakis akkor stabil, illetve erösen stabil, ha a rendszer monodrómia mátrixa stabil, illetve erốsen stabil.

Tekintsük most az

$$
\ddot{x}+a(t) x=0, \quad a(t+T)=a(t), t \in \mathbb{R}
$$

Hill-egyenletet. A Liouville-tétel [1] alapján $\operatorname{det} M=\operatorname{det} \Phi(T)=1$, ezért a monodrómia sajátértékeinek szorzata 1-gyel egyenlő. Ezek után, fölírva a (3.3) egyenlet karakterisztikus egyenletét kapjuk, hogy

$$
\lambda^{2}-\operatorname{Tr} \Phi(T) \lambda+\operatorname{det} \Phi(T)=\lambda^{2}-\operatorname{Tr} \Phi(T) \lambda+1=0
$$

Föntebb már említettük, hogy például a [32] kötetben megtalálható az a tétel, mely a (3.2) rendszerek stabilitásáról szól. Ezzel a tétellel összevetve a (3.4) egyenlet gyökeit adódik a következô állítás.

3.6. Tétel. Legyen $\Phi(t)$ a (3.3) egyenlet azon alapmátrixa, melyre teljesül, hogy $\Phi(0)=E$, ahol $E$ a $2 \times 2$-es egységmátrix. $H a|\operatorname{Tr} \Phi(T)|<2$, akkor a (3.3) egyenlet $x=0$ megoldása stabil. Továbbá, ha $|\operatorname{Tr} \Phi(T)|>2$, akkor a (3.3) egyenlet $x=0$ megoldása instabil.

A 3.1 és a 3.2 ábrák a tételben megfogalmazott eseteknek megfelelôen mutatják be a sajátértékek elhelyezkedését az origó körüli egységkörön.

\subsubsection{A Floquet-elv használata}

Alkalmazzuk az elôző alfejezetben kimondottakat a (3.1) egyenletre. Rögzített $\varepsilon$ mellett az $a(t)$ lépcsôsfüggvény, így a (3.1) szakaszonként konstans együtthatós, emiatt a megoldását explicite meg tudjuk adni. Ezeket a megoldásokat 


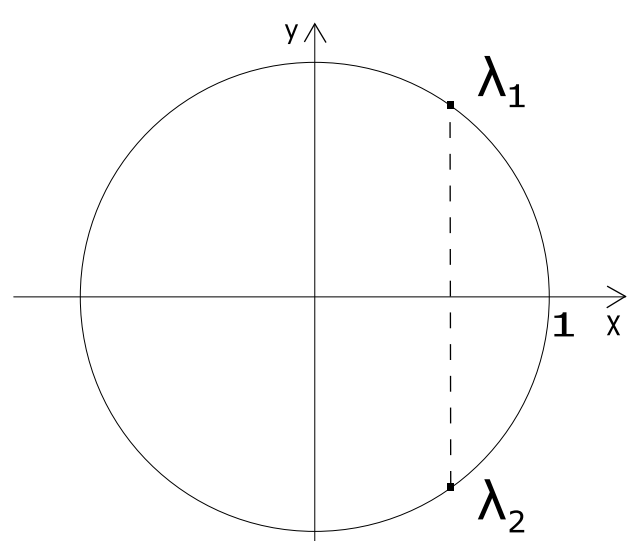

3.1. ábra. Erôsen stabil monondrómia sajátértékei

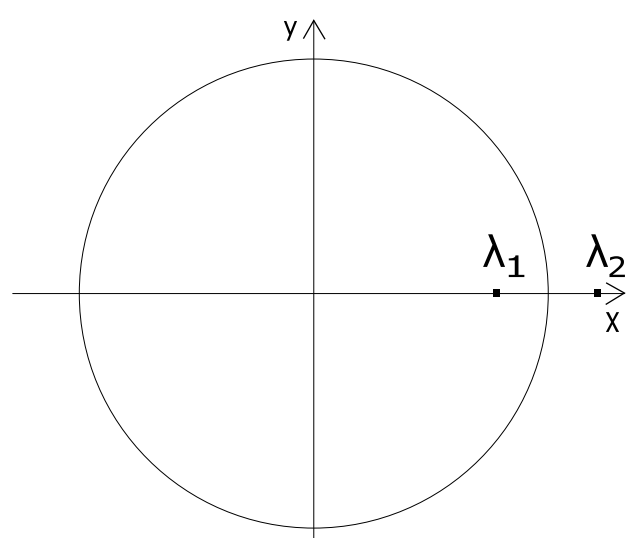

3.2. ábra. Instabil monodrómia sajátértékei

úgy keressük, hogy az alaprendszer kielégítse az $x(0)=1, \dot{x}(0)=0$, illetve az $x(0)=0, \dot{x}(0)=1$ föltételeket annak érdekében, hogy $\Phi(0)=E$ teljesüljön. Ekkor a $2 k T \leq t<(2 k+1) T$ intervallumokon

$$
\Phi_{1}(t)=\left(\begin{array}{ll}
\cos \sqrt{\frac{g}{l-\varepsilon}} t & \sqrt{\frac{l-\varepsilon}{g}} \sin \sqrt{\frac{g}{l-\varepsilon}} t \\
-\sqrt{\frac{g}{l-\varepsilon}} \sin \sqrt{\frac{g}{l-\varepsilon}} t & \cos \sqrt{\frac{g}{l-\varepsilon}} t
\end{array}\right),
$$

illetve a $(2 k+1) T \leq t<(2 k+2) T$ intervallumokon 


$$
\Phi_{2}(t)=\left(\begin{array}{ll}
\cos \sqrt{\frac{g}{l+\varepsilon}} t & \sqrt{\frac{l+\varepsilon}{g}} \sin \sqrt{\frac{g}{l+\varepsilon}} t \\
-\sqrt{\frac{g}{l+\varepsilon}} \sin \sqrt{\frac{g}{l+\varepsilon}} t & \cos \sqrt{\frac{g}{l+\varepsilon}} t
\end{array}\right)
$$

ahol $k \in \mathbb{N}$. A 3.6 tétel alkalmazásához föl kell írni a rendszer monodrómia mátrixát, mely a (3.5) és (3.6) mátrixok $t=T$ helyen vett értékeinek szorzata adja [1]. Könnyü látni, hogy a monodrómia $\varepsilon$ paramétertól való függése miatt a nyomára kirótt feltétel további vizsgálata egyáltalán nem egyszerú, sorfejtéseken alapuló becslésekre vezet. A részleteket illetően ismét az [1] jegyzetre utalunk. Célunk az, hogy pontos térképet adjunk meg elkerülve a monodrómia mátrix fölírását, illetve annak nyoma vizsgálatát. Azt viszont nagyon lényeges megjegyezni, hogy a 3.6 tételból következik, hogy az instabilitási tartomány határát a $|\operatorname{Tr} \Phi(T)|=2$ egyenlet írja le. Ez jelen esetben azt jelenti, hogy a karakterisztikus tényezők - lévén valós számok, amelyek szorzata 1 - vagy mindketten 1-gyel, vagy mindketten -1-gyel egyenlőek. Ebből az következik, hogy az instabilitási tartomány határa a $(T, \varepsilon)$ sík azon pontjaiból áll, amely pontokhoz tartozó megoldások $2 T$ - vagy $4 T$-periodikusak, tekintve, hogy a (3.1) rendszer együtthatófüggvénye $2 T$-periodikus. Ez utóbbi gondolaton alapul az az eljárás, melyet a [10] dolgozatunkban közöltünk, és a következó alfejezetben mutatunk be.

\subsection{Elemi úton}

Ahogyan az előzô fejezet végén megjegyeztük, már egy igen egyszerû mechanikai modell vizsgálatánál előfordulhat, hogy az egyébként igen termékeny Floquet-elmélet nehéz számításokba torkollik, ahogyan ezt a [8] múben is megjegyzi a szerzô. Ebben a fejezetben megmutatjuk, hogy a (3.1) egyenlettel modellezett hintázás problémáját elemi geometriai megfontolások segítségével is meg lehet oldani. Nevezetesen, megalkotjuk a $(T, \varepsilon)$ sík instabilitási zónájának határát jelentô $T=f(\varepsilon), T=g(\varepsilon)$ görbéket, melyekrôl tudjuk, hogy pontjaik megfelelnek a (3.1) egyenlet $2 T$ - vagy $4 T$-periodikus megoldásainak. Azt is megmutatjuk, hogy $f(\varepsilon), g(\varepsilon)$ a $((k / 2)(\pi \sqrt{l / g}), 0)(k \in \mathbb{N})$ pontok valamelyikéhez konvergálnak, amint $\varepsilon \rightarrow 0$. Ennek a ténynek van egy fontos gyakorlati jelentése. Ha 
minél kisebb energiabefektetéssel akarunk destabilizálni, illetve kis gyermeket akarunk megtanítani hintázni $(\varepsilon>0$ kicsi $)$, akkor a $T=(k / 2)(\pi \sqrt{l / g}),(k \in \mathbb{N})$ kritikus félperiódusok valamelyikét kell választani.

\subsubsection{Technikai háttér}

A destabilizálási probléma megoldásának elsô lépéseként próbáljunk olyan feltételeket megadni, melyek garantálják, hogy a (3.1) rendszer $t \mapsto\left(x\left(t ; x_{0}, \dot{x}_{0}\right), \dot{x}\left(t ; x_{0}, \dot{x}_{0}\right)\right)$ trajektóriája elindulva a fázissík egy $P\left(x_{0}, \dot{x}_{0}\right)$ pontjából $2 T$ idô alatt visszatérjen a sík azon $L$ egyenesére, mely összeköti a $(0,0)$ koordinátájú origót a $P$ ponttal, vagyis $\left(x\left(2 T ; x_{0}, \dot{x}_{0}\right), \dot{x}\left(2 T ; x_{0}, \dot{x}_{0}\right)\right) \in L$. Egy ilyen trajektória az origóhoz közeledik, illetve távolodik az origótól attól függően, hogy $\left(x\left(2 T ; x_{0}, \dot{x}_{0}\right), \dot{x}\left(2 T ; x_{0}, \dot{x}_{0}\right)\right)$ pont közelebb, illetve távolabb van az origótól, mint az $\left(x_{0}, \dot{x}_{0}\right)$ pont. Ha a két pont ugyanolyan távol van az origótól, akkor a megoldás vagy $2 T$-, vagy $4 T$-periodikus.

A Bevezetésben leírt módszerrel a (3.1) egyenlet a (2.6) alakú rendszerbe transzformálható. Szintén a Bevezetésben említetteknek megfelelően a (2.6) dinamikájának lépései a fázissíkon a következóképpen írhatóak le. A fázispont az $\left(x_{0}, y_{0}\right)$ pontból indulva egy origó középpontú kör mentén mozogva egy $\left(x_{1}, y_{1}\right)$ pontba kerül, majd egy $a_{1} / a_{2}>1$ mértékú dilatáció történik az $y$-tengellyel párhuzamosan, így kerül egy $\left(x_{2}, y_{2}\right)$ pontba. Ezután ismét egy origó középpontú köríven mozog $\left(\left(x_{3}, y_{3}\right)\right)$, majd „ugrik" egy $a_{2} / a_{1}$ mértékủ kontrakcióval, így kerülve az $\left(x_{4}, y_{4}\right)$ pontba. Ezek a lépések egymás utáni végtelen ismétlése írja le a fázispont mozgását a fázissíkon, lásd a 3.3 ábrát.

A (2.6) impulzív rendszert az $(x, y)$ sík egy diszkrét dinamikus rendszereként is interpretálhatjuk. Vezessük be ugyanis az $(r, \varphi)$ polárkoordinátákat a

$$
x=r \cos \varphi, \quad y=r \sin \varphi \quad(r>0,-\infty<\varphi<\infty)
$$

formulákkal. Tudjuk, hogy $r^{\prime}(t) \equiv 0(2.6)$ bármely megoldása mentén minden $\left[t_{k-1}, t_{k}\right)$ intervallumban. Mivel

$$
x^{\prime}(t)=-r(t) \varphi^{\prime}(t) \sin \varphi(t)=a_{k} y(t)=a_{k} r(t) \sin \varphi(t) \quad\left(t_{k-1} \leq t<t_{k}\right),
$$

ezért kapjuk, hogy

$$
\varphi^{\prime}(t)=-a_{k} \quad\left(t_{k-1} \leq t<t_{k}\right)
$$




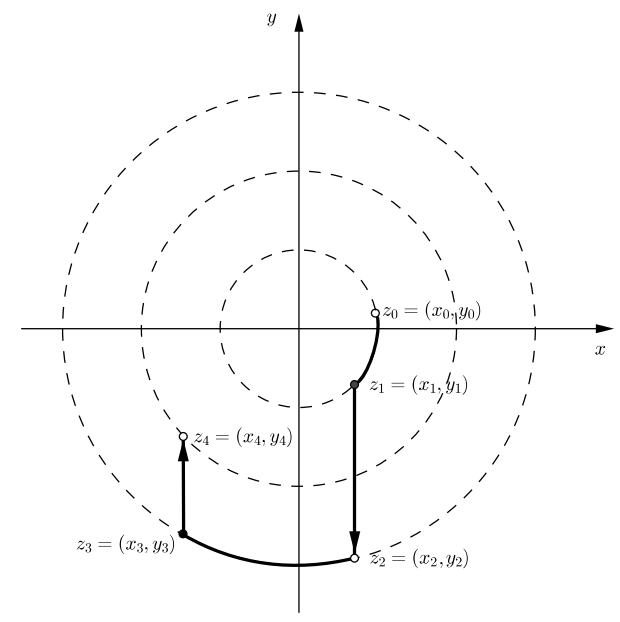

3.3. ábra. A (3.1) rendszernek megfelelő (2.6) dinamika lépései

Vagyis a (2.6) folytonos komponense egy $a_{k}$ szögsebességgel történô, origó körüli egyenletes forgatás negatív irányban. Jelölje az $R(\theta)$, illetve a $C(\kappa)$ rendre a forgatást, illetve az impulzív effektust megadó mátrixot, tehát

$$
\begin{aligned}
& R(\theta)=\left(\begin{array}{cc}
\cos \theta & \sin \theta \\
-\sin \theta & \cos \theta
\end{array}\right) \quad(-\infty<\theta<\infty), \\
& C(\kappa)=\left(\begin{array}{cc}
1 & 0 \\
0 & \kappa
\end{array}\right) \quad\left(\kappa=\frac{a_{k}}{a_{k+1}}, 0<\kappa<\infty\right) .
\end{aligned}
$$

Ekkor a (2.6) rendszerrel ekvivalens diszkrét dinamikus rendszer:

$$
\left(\begin{array}{c}
x_{k+1} \\
y_{k+1}
\end{array}\right)=C\left(\frac{a_{k+1}}{a_{k+2}}\right) R\left(a_{k+1}\left(t_{k+1}-t_{k}\right)\right)\left(\begin{array}{c}
x_{k} \\
y_{k}
\end{array}\right) \quad(k=0,1,2, \ldots) .
$$

Tekintsük ezt a (3.9) rendszert polárkoordinátákban. Jelölje $\left(r_{R}, \varphi_{R}\right)$, illetve $\left(r_{C}, \varphi_{C}\right)=(\rho(r, \varphi ; \kappa), \phi(\varphi ; \kappa))$ az $(r, \varphi)$ pont képét rendre az $R(\theta)$ forgatás, illetve a $C(\kappa)$ kontrakció-dilatáció során. Azt könnyú látni, hogy $r_{R}(r, \varphi)=$ $r, \varphi_{R}(r, \varphi)=\varphi-\theta$. Ezen felül pedig

$$
\begin{gathered}
\rho(r, \varphi ; \kappa)=\sqrt{x^{2}+\kappa^{2} y^{2}}=r \sqrt{1+\left(\kappa^{2}-1\right) \sin ^{2} \varphi}=f(\varphi ; \kappa) r, \\
f(\varphi, \kappa):=\sqrt{1+\left(\kappa^{2}-1\right) \sin ^{2} \varphi}, \quad(\kappa>0,-\infty<\varphi<\infty) .
\end{gathered}
$$


Szintén könnyú észrevenni, hogy $\tan \phi(\varphi ; \kappa)=\kappa y / x=\kappa \tan \varphi(x \neq 0)$, azaz

$$
\phi(\varphi ; \kappa):=\left\{\begin{array}{ll}
\arctan (\kappa \tan \varphi)+\left[\frac{\varphi+\frac{\pi}{2}}{\pi}\right] \cdot \pi, & \text { ha } \varphi \neq(2 k+1) \frac{\pi}{2}, \\
\varphi, & \text { ha } \varphi=(2 k+1) \frac{\pi}{2},
\end{array} \quad(k \in \mathbb{Z}),\right.
$$

ahol $[x]$ jelöli az $x \in \mathbb{R}$ szám egészrészét. Ezek alapján a (2.6) polárkoordinátákban a következő alakú:

$$
\left\{\begin{array}{l}
r_{k+1}=f\left(\varphi_{k}-a_{k+1}\left(t_{k+1}-t_{k}\right) ; \frac{a_{k+1}}{a_{k+2}}\right) r_{k}, \\
\varphi_{k+1}=\phi\left(\varphi_{k}-a_{k+1}\left(t_{k+1}-t_{k}\right) ; \frac{a_{k+1}}{a_{k+2}}\right),
\end{array}(k=0,1,2, \ldots) .\right.
$$

Az $f$ és $\phi$ függvények tulajdonságait a következô lemma foglalja össze. A lemma bizonyítását megtaláljuk a [17] cikkben.

3.7. Lemma. 1. Bármely $\kappa>0$ esetén az $f(\cdot ; \kappa): \mathbb{R} \rightarrow(0, \infty)$ függvény páros és $\pi$-periodikus, továbbá

$$
f\left(\phi(\varphi ; \kappa) ; \frac{1}{\kappa}\right)=\frac{1}{f(\varphi ; \kappa)} \quad(\varphi \in \mathbb{R})
$$

(lásd a 3.4 ábrát).

2. Bármely $\kappa>0$ esetén a $\phi(\cdot ; \kappa)$ és $a \phi(\cdot+\pi / 2 ; \kappa)-\pi / 2$ függvény páratlan, $\phi(\cdot+k \pi ; \kappa)=\phi(\cdot ; \kappa)+k \pi(k \in \mathbb{Z})$, valamint

$$
\phi\left(\phi(\varphi ; \kappa) ; \frac{1}{\kappa}\right)=\varphi \quad(\varphi \in \mathbb{R}) .
$$

3. Ha $0<\kappa<1$, akkor minden $k \in \mathbb{Z}$ esetén

$$
\begin{array}{ll}
\phi(\varphi ; \kappa)<\varphi & \text { if } 2 k \frac{\pi}{2}<\varphi<(2 k+1) \frac{\pi}{2}, \\
\phi(\varphi ; \kappa)>\varphi & \text { if }(2 k+1) \frac{\pi}{2}<\varphi<2(k+1) \frac{\pi}{2} .
\end{array}
$$

4. $H a \kappa>1$, akkor a $\phi(\varphi ; \kappa)$ és $\varphi$ közötti relációk ellentétes irányban érvényesek (lásd a 3.5 ábrát).

\subsubsection{Periodikus, origóhoz közeledô és origótól távolodó pályák}

Annak érdekében, hogy tetszóleges $2 T$ gerjesztési periódus esetén ugyanaz $(2 L)$ legyen az egyenlet periódusa, vezessük be a $\tau=(L / T) t$ új független 


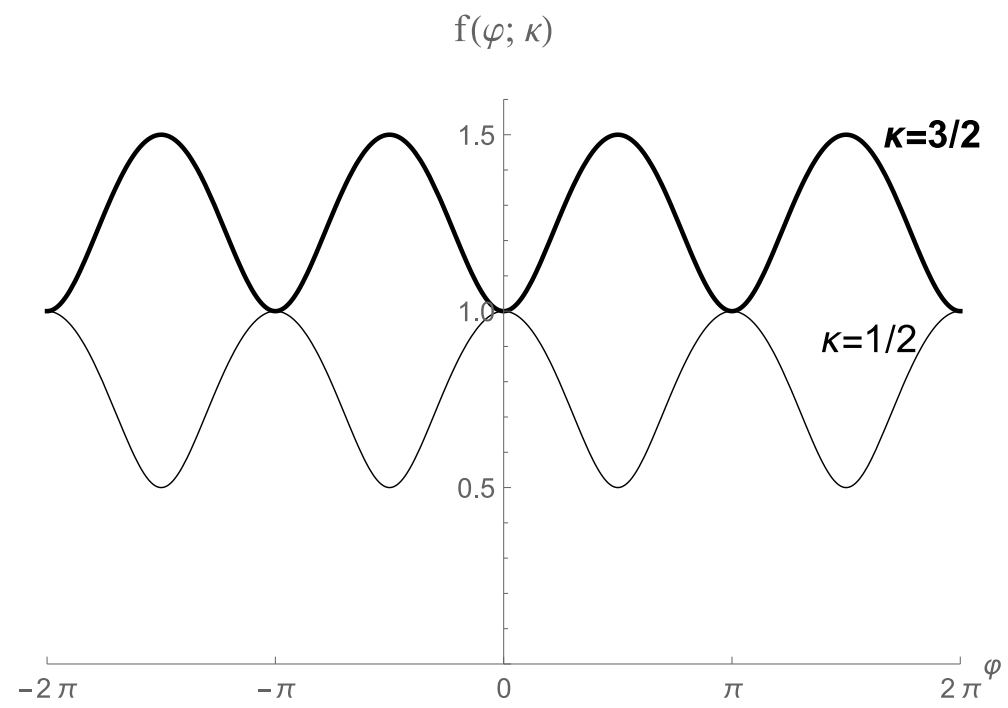

3.4. ábra. Az $f$ függvény grafikonja

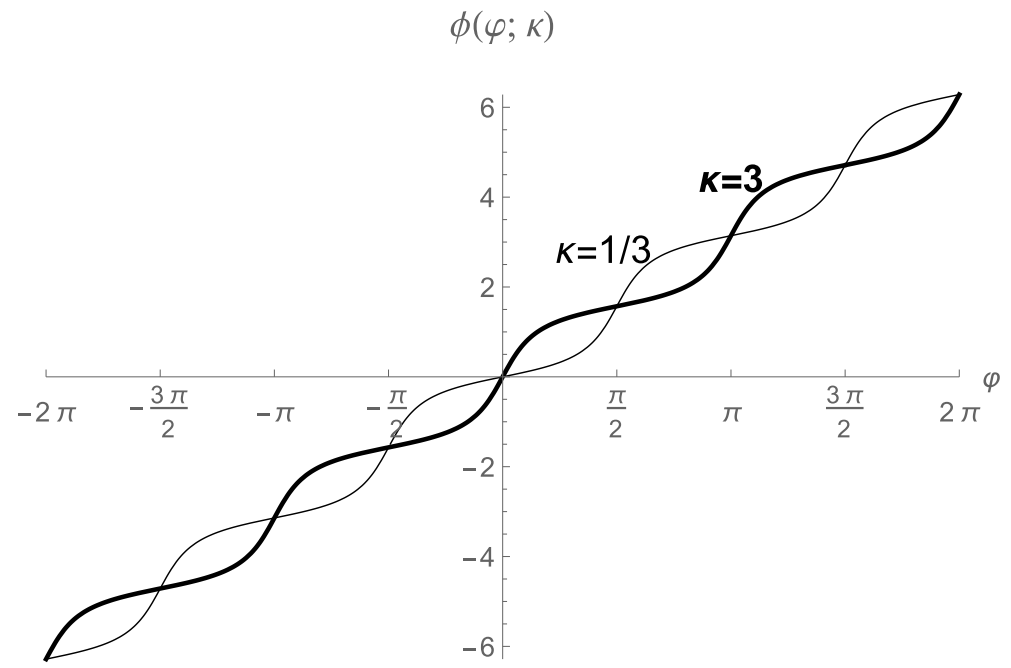

3.5. ábra. A $\phi$ függvény grafikonja

változót. Az új és a régi függó változó kapcsolatát ekkor a $z(\tau):=x((T / L) \tau)$ összefüggés írja le, és a mozgásegyenlet az

$$
\ddot{z}+A^{2}(\tau) z=0
$$


alakot ölti, ahol

$$
A(\tau)=\frac{T}{L} a\left(\frac{T}{L} \tau\right)= \begin{cases}\frac{T}{L} \sqrt{\frac{g}{l-\varepsilon}}, & \text { ha } 2 k L \leq \tau<(2 k+1) L, \\ \frac{T}{L} \sqrt{\frac{g}{l+\varepsilon}}, & \text { ha }(2 k+1) L \leq \tau<(2 k+2) L, k \in \mathbb{N} .\end{cases}
$$

Nem fog félreértésekre vezetni, ha visszatérünk a megszokott jelöléseinkre: $t$ a $\tau$ helyett és $x, \dot{x}$ a $z, \dot{z}$ helyett. Bevezetve a $\lambda:=T / L$ paramétert, a (3.11) egyenlet a következó alakban írható:

$$
Q(t)=\left\{\begin{array}{l}
a_{1}^{2}=a_{1}^{2}(\varepsilon):=\frac{g}{l-\varepsilon}, \quad \text { ha } \quad 2 k L \leq t<(2 k+1) L, \\
a_{2}^{2}=a_{2}^{2}(\varepsilon):=\frac{g}{l+\varepsilon}, \quad \text { ha } \quad(2 k+1) L \leq t<(2 k+2) L \quad(k \in \mathbb{N}) .
\end{array}\right.
$$

Legyen

$$
\begin{aligned}
t_{k} & :=k L, \quad a_{2 k+1}:=\lambda a_{1}, a_{2 k+2}:=\lambda a_{2} \quad(k \in \mathbb{N}), \\
D & :=\frac{a_{1}}{a_{2}}, \quad d:=\frac{a_{2}}{a_{1}} .
\end{aligned}
$$

Ezzel a választással a (3.12) egyenletet (2.4) alakúra hoztuk. A (3.9) dinamikus rendszernek megfelelö rendszer az $x, y:=\dot{x}_{k} / a_{k}$ változókkal:

$$
\left\{\begin{array}{l}
\left(\begin{array}{l}
x_{2 \ell+1} \\
y_{2 \ell+1}
\end{array}\right)=C(D) R\left(\lambda a_{1} L\right)\left(\begin{array}{c}
x_{2 \ell} \\
y_{2 \ell}
\end{array}\right), \\
\left(\begin{array}{l}
x_{2 \ell+2} \\
y_{2 \ell+2}
\end{array}\right)=C(d) R\left(\lambda a_{2} L\right)\left(\begin{array}{l}
x_{2 \ell+1} \\
y_{2 \ell+1}
\end{array}\right) \quad(l \in \mathbb{N}) .
\end{array}\right.
$$

Tekintsük rendszerünket a (3.7) által definiált polárkoordinátákban. A $t_{0}=0$ idôpillanatban indítsunk el egy trajektóriát az $\left(r_{0}, \varphi_{0}\right)$ pontból. Ekkor a dinamika föntebb leírt lépéseit a következô módon tudjuk megadni:

$$
\begin{array}{ll}
r_{0}:=r(0), & \varphi_{0}: \equiv \varphi(0) \quad(\bmod 2 \pi),-\pi \leq \varphi_{0}<\pi ; \\
r_{1}:=r(L-0)\left(=r_{0}\right), & \varphi_{1}:=\varphi(L-0) ; \\
r_{2}:=r(L)=f\left(\varphi_{1} ; D\right) r_{1}, & \varphi_{2}:=\varphi(L)=\phi\left(\varphi_{1} ; D\right) ; \\
r_{3}:=r(2 L-0)\left(=r_{2}\right), & \varphi_{3}:=\varphi(2 L-0) ; \\
r_{4}:=r(2 L)=f\left(\varphi_{3} ; d\right) r_{3}, & \varphi_{4}:=\varphi(2 L)=\phi\left(\varphi_{3} ; d\right) .
\end{array}
$$


Az indexelés eltérô a (3.10)-hez és a (3.13)-höz képest, lásd a 3.3 ábrát. A $Q$ függvény periodicitása miatt elegendő az első öt pontot megadni, a többi magától értetődik.

Ahogyan korábban utaltunk rá, olyan megoldásoknak megfelelő fázisgörbéket írunk le, melyek egy adott pontból indulva visszatérnek az adott pontot az origóval összekötô egyenesre. Ennek felel meg az alább definiált, úgynevezett szögperiodikus megoldás, ami azt fejezi ki, hogy az $(r, \varphi)$ megoldás koordinátái közül a $\varphi$ szögváltozó periodikus moduló $2 \pi$, (lásd a 3.6 ábrát), illetve moduló $4 \pi$, azaz $\varphi(t) \equiv \varphi(t+2 L)(\bmod 2 \pi)$, illetve $\varphi(t) \equiv \varphi(t+2 L)(\bmod 4 \pi)$, a rádiusz pedig tetszóleges lehet.

3.8. Definíció. A (3.13) rendszer egy megoldásáról azt mondjuk, hogy $2 \pi$ modulusú szögperiodikus, illetve $4 \pi$ modulusú szögperiodikus, ha $\varphi(2 L) \equiv \varphi_{0} \quad(\bmod 2 \pi)$, illetve $\quad \varphi(2 L) \equiv \varphi_{0}-\pi \quad(\bmod 2 \pi)$

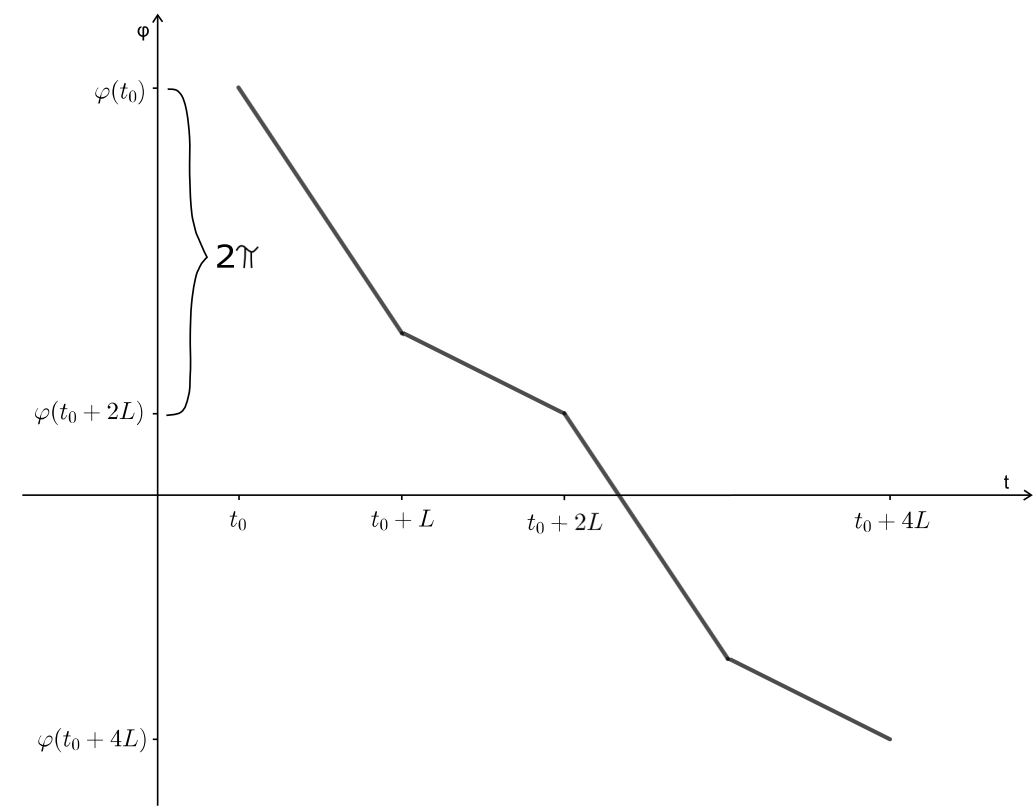

3.6. ábra. $\varphi(t) 2 \pi$ modulusú szögperiodikus esetben

3.9. Definíció. $A$ (3.13) egy $2 \pi$ modulusú, vagy $4 \pi$ modulusú szögperiodikus megoldását (origóhoz) közeledőnek, illetve (az origótól) távolodónak (lásd a 3.7 ábrát) mondunk, ha

$$
r_{4}<r_{0} \text {, illetve } r_{4}>r_{0}
$$




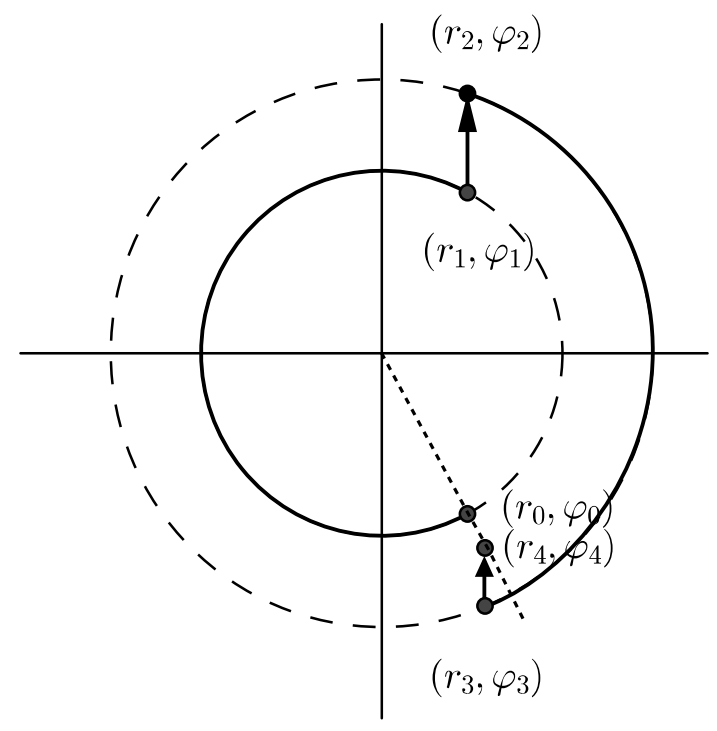

3.7. ábra. A (3.13) dinamika elsố négy lépése origótól távolodó, $2 \pi$ modulusú szögperiodikus megoldás esetén

Ezek alapján a (3.13) rendszer egy megoldása $2 L$-periodikus, illetve $4 L$-periodikus pontosan akkor, ha szögperiodikus $2 \pi$, illetve $4 \pi$ modulussal és $r_{4}=r_{0}$, lásd a 3.8 ábrát.

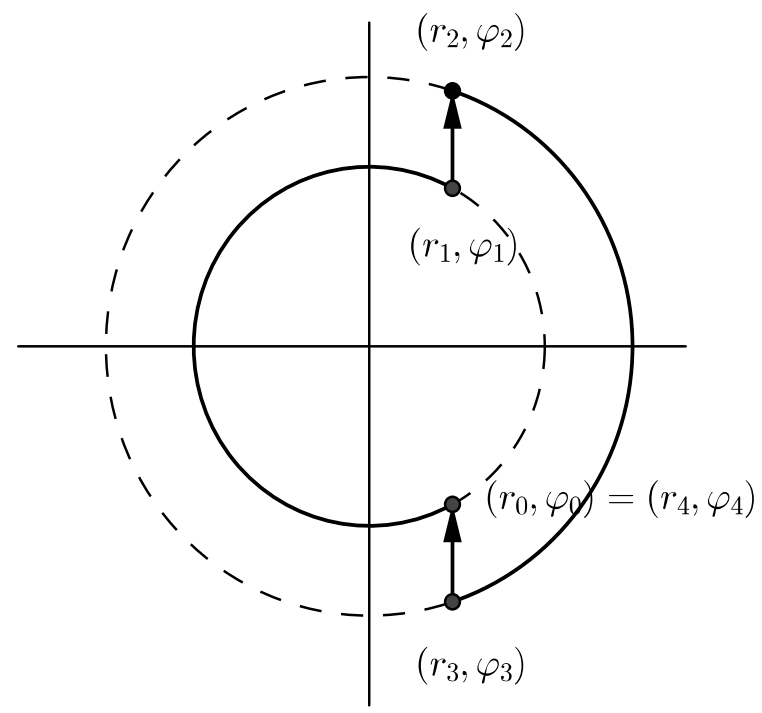

3.8. ábra. A (3.13) dinamika elsô négy lépése $2 L$-periodikus megoldás esetén 
A következókben megvizsgáljuk, hogy a (3.13) egyenletnek milyen szükséges és elegendő föltételek mellett létezik szögperiodikus, illetve periodikus megoldása, illetve milyen feltételekkel tudjuk garantálni az origótól távolodó megoldás létét. Mindezek alapját képezi a következô lemma.

3.10. Lemma. 1. A (3.13) egy szögperiodikus megoldása az origóhoz közeledó, illetve az origótól távolodó akkor és csakis akkor, ha

$$
f\left(\varphi_{1} ; D\right)<f\left(\varphi_{0} ; D\right) \text {, illetve } f\left(\varphi_{1} ; D\right)>f\left(\varphi_{0} ; D\right)
$$

2. A (3.13) $2 \pi$, illetve $4 \pi$ modulusú szögperiodikus megoldása periodikus $2 L$, illetve $4 L$ periódussal akkor és csakis akkor, ha

$$
f\left(\varphi_{1} ; D\right)=f\left(\varphi_{0} ; D\right)
$$

Bizonyítás. Tekintsük a (3.13) egy $2 \pi$ modulusú szögperiodikus megoldását. Ekkor $\varphi_{4}=\varphi_{0}-2(p+1) \pi$ valamely $p \in \mathbb{N}$ esetén. A 3.7 lemma állításait használva azt írhatjuk, hogy

$$
\varphi_{3}=\phi^{-1}\left(\varphi_{4} ; d\right)=\phi\left(\varphi_{0}-2(p+1) \pi ; D\right)=\phi\left(\varphi_{0} ; D\right)-2(p+1) \pi
$$

és

$$
r_{4}=f\left(\varphi_{3} ; d\right) r_{3}=f\left(\phi\left(\varphi_{0} ; D\right) ; d\right) r_{3}=\frac{1}{f\left(\varphi_{0} ; D\right)} r_{3}=\frac{f\left(\varphi_{1} ; D\right)}{f\left(\varphi_{0} ; D\right)} r_{0} .
$$

A lemma mindhárom, $2 \pi$ modulusú szögperiodikus megoldásra vonatkozó állítását ezekből könnyen le tudjuk olvasni.

A $4 \pi$ modulusú esetben $\varphi_{4}=\varphi_{0}-(2 p+1) \pi(p \in \mathbb{N})$, ugyanakkor könnyú látni, hogy ez a bizonyítást nem befolyásolja.

A 3.10 lemma azt mondja ki tehát, hogy a $\varphi_{0}$ és a $\varphi_{1}$ egyértelmúen meghatározza a szög-periodikus trajektória mentén mozgó fázispontnak az origótól vett távolságát, amely távolság vagy nullába tart vagy a végtelenbe divergál vagy periodikusan változik, ha $t \rightarrow \infty$. A $\left(\varphi_{0}, \varphi_{1}\right)$ sík pontjait osztályozzuk ennek a három tulajdonságnak megfelelóen. Tekintsük e célból a $\left(\varphi_{0}, \varphi_{1}\right)$ sík $0 \leq \varphi_{0}<\pi, \varphi_{1}<\varphi_{0}$ feltételeknek eleget tevő részhalmazát, ahol az első föltétel abból adódik, hogy a fázispont köríveket fut be, így a szimmetria miatt elegendő a fölsô félkört vizsgálni, a második reláció pedig a dinamikából kapható, hiszen tudjuk, hogy a szög csökken az origó körüli forgatás során. Kihasználva az $f$ 
függvény tulajdonságait, melyeket a 3.7 lemmában soroltunk föl, könnyư látni, hogy az $f\left(\varphi_{1} ; D\right)=f\left(\varphi_{0} ; D\right)$ egyenlőséget mindazon pontok teljesítik, melyek rajta vannak azokon az egyeneseken, melyek egyenlete:

$$
\varphi_{1}=\varphi_{0}-j \pi, \quad \varphi_{1}=\left(\pi-\varphi_{0}\right)-j \pi \quad(j \in \mathbb{N}),
$$

lásd a 3.9 és 3.10 ábrákat.

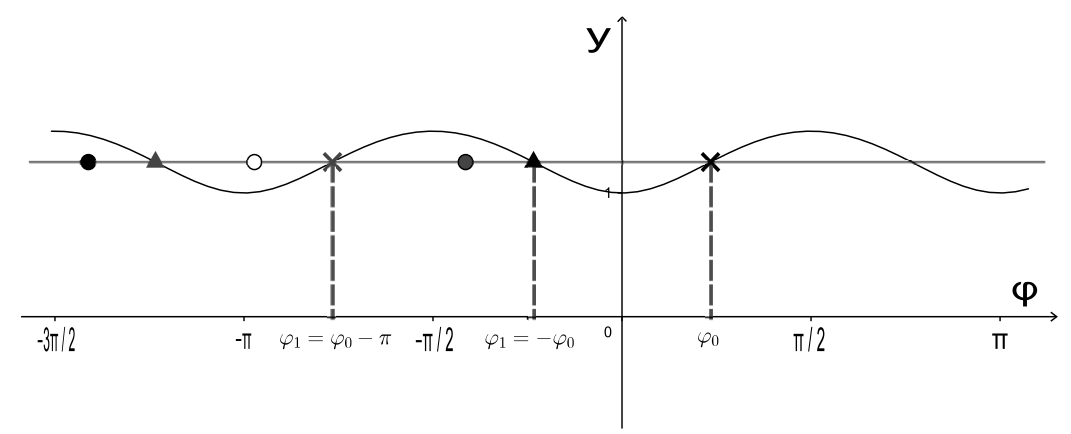

3.9. ábra. Az $f\left(\varphi_{1} ; D\right)=f\left(\varphi_{0} ; D\right)$ megoldásai $0<\varphi_{0} \leq \pi / 2$ esetén

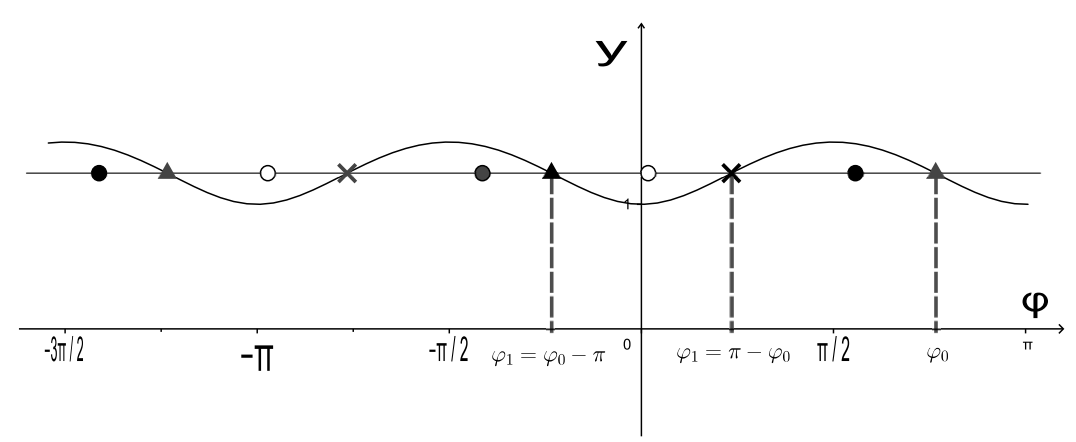

3.10. ábra. Az $f\left(\varphi_{1} ; D\right)=f\left(\varphi_{0} ; D\right)$ megoldásai $\pi / 2<\varphi_{0} \leq \pi$ esetén

Az $f\left(\varphi_{1} ; D\right)>f\left(\varphi_{0} ; D\right)$ egyenlőtlenség megoldáshalmazát megadó intervallumok, melyek a 3.9 és a 3.10 ábrákról leolvashatóak, és azokon tele fekete pontokkal vannak megjelölve, a következő két típus valamelyikéból állnak:

(a) $0 \leq \varphi_{0}<\frac{\pi}{2}$ :

$$
\varphi_{0}-(j+1) \pi<\varphi_{1}<-\varphi_{0}-j \pi \quad(j \in \mathbb{N})
$$

(b) $\frac{\pi}{2} \leq \varphi_{0}<\pi$ :

$$
-\varphi_{0}-(j-1) \pi<\varphi_{1}<\varphi_{0}<\varphi_{0}-j \pi \quad(j \in \mathbb{N})
$$


(lásd a 3.11 ábra satírozott részét). Az $f\left(\varphi_{1} ; D\right)<f\left(\varphi_{0} ; D\right)$ egyenlőtlenség megoldáshalmazát megadó intervallumokat, melyeket a 3.9 és a 3.10 ábrákról szintén leolvashatunk, és üres karikával jelöltünk, a következók határozzák meg (a 3.11 ábra nem satírozott része):

(a) $0 \leq \varphi_{0}<\frac{\pi}{2}$ :

$$
-\varphi_{0}-j \pi<\varphi_{1}<\varphi_{0}-j \pi \quad(j \in \mathbb{N})
$$

(b) $\frac{\pi}{2} \leq \varphi_{0}<\pi$ :

$$
\varphi_{0}-(j+1) \pi<\varphi_{1}<-\varphi_{0}-(j-1) \pi \quad(j \in \mathbb{N}) .
$$

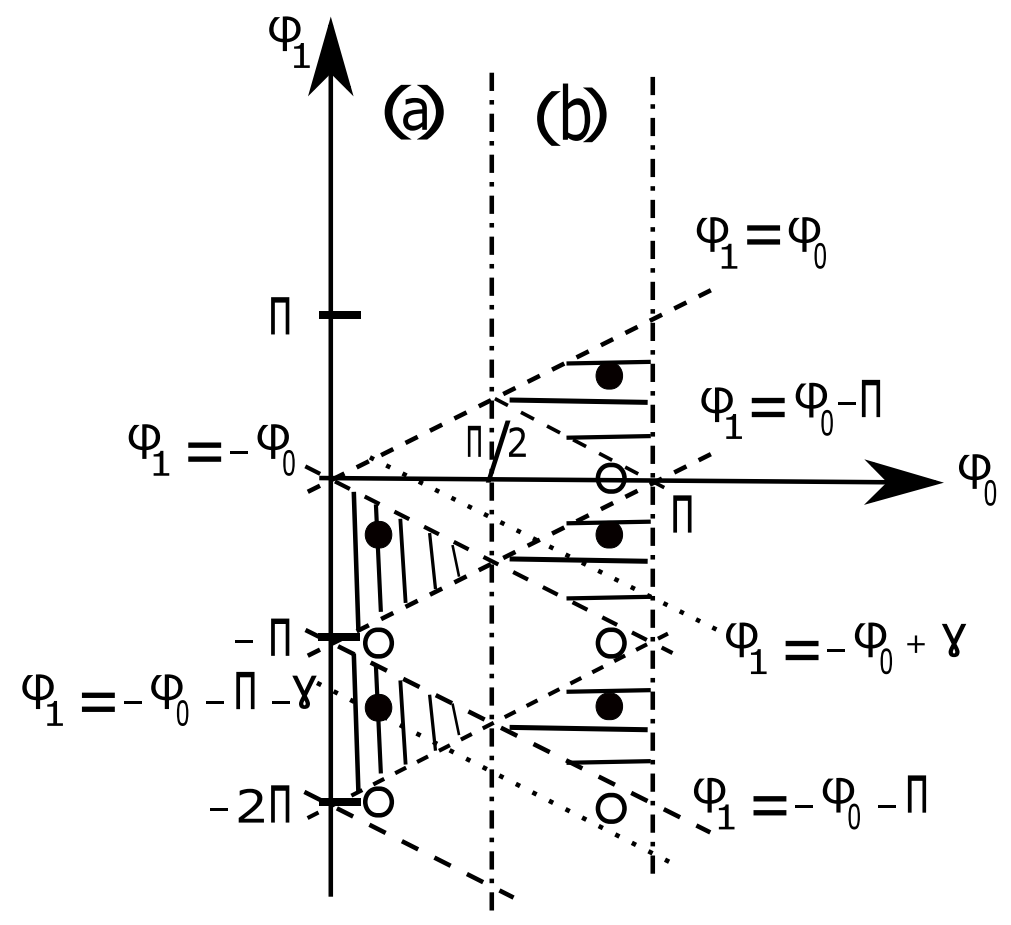

3.11. ábra. A 3.10 lemmában foglalt egyenlőtlenségek megoldáshalmazai

A (3.8) egyenlet figyelembe vételével írhatjuk, hogy

$$
\varphi_{1}-\varphi_{0}=-a_{1} \lambda L, \quad \varphi_{3}-\varphi_{2}=-a_{2} \lambda L
$$

A (3.15) első egyenlőségét a 3.10 lemmával összevetve a következôket állíthatjuk. Adott $a_{1}$ és $\lambda$ mellett a $2 L$ - vagy a $4 L$-periodikus megoldást egyértelmúen meghatározza a $\varphi_{0}$ értéke, nevezetesen a megoldás $2 L$-periodikus vagy $4 L$ periodikus, ha vagy 
( $\alpha) a_{1} \lambda \frac{L}{\pi}$ egész és $\varphi_{0}$ tetszőleges,

vagy

( $\beta) a_{1} \lambda \frac{L}{\pi}$ nem egész, és vagy

$$
\text { (a) } \varphi_{0}=\left\{a_{1} \lambda \frac{L}{\pi}\right\} \frac{\pi}{2}
$$

vagy

$$
\text { (b) } \varphi_{0}=\left(\left\{a_{1} \lambda \frac{L}{\pi}\right\}+1\right) \frac{\pi}{2} \text {, }
$$

ahol $\{\xi\}$ a $\xi \in \mathbb{R}$ törtrészét jelöli. Ugyancsak a (3.15) és a 3.10 lemma segítségével bizonyítható a következó lemma [10].

3.11. Lemma. 1. A (3.13) egy megoldása szögperiodikus $2 \pi$ modulussal pontosan akkor, ha van olyan $p \in \mathbb{N}$ szám, melyre

$$
\phi\left(\varphi_{0} ; D\right)-\phi\left(\varphi_{0}-a_{1} \lambda L ; D\right)-2(p+1) \pi=-a_{2} \lambda L .
$$

2. A (3.13) egy megoldása szögperiodikus $4 \pi$ modulussal pontosan akkor, ha van olyan $p \in \mathbb{N}$ szám, melyre

$$
\phi\left(\varphi_{0} ; D\right)-\phi\left(\varphi_{0}-a_{1} \lambda L ; D\right)-(2 p+1) \pi=-a_{2} \lambda L .
$$

Bizonyítás. Szükségesség. 1. A dinamika és a (3.14) ismeretében írhatjuk, hogy

$$
\varphi_{2}=\phi\left(\varphi_{1} ; D\right), \quad \varphi_{3}=\phi\left(\varphi_{0} ; D\right)-2(p+1) \pi
$$

Figyelembe véve (3.15) egyenlôséget kapjuk a (3.17) kifejezést.

2. Ahogyan a 3.10 lemma bizonyítása során említettük, a $4 \pi$ modulusú esetben

$$
\varphi_{2}=\phi\left(\varphi_{1} ; D\right), \quad \varphi_{3}=\phi\left(\varphi_{0} ; D\right)-(2 p+1) \pi
$$

egyenlőségek teljesülnek a (3.19) helyett. Ekkor a (3.15) fölhasználásával a (3.18) formulához jutunk.

Elegendôség. 1. Tegyük föl, hogy (3.17) teljesül. Ekkor a (3.15) második egyenlőségét figyelembe véve kapjuk

$$
\varphi_{3}=\varphi_{2}-a_{2} \lambda L=\phi\left(\varphi_{0}-a_{1} \lambda L ; D\right)-a_{2} \lambda L=\phi\left(\varphi_{0} ; D\right)-2(p+1) \pi .
$$


Következésképpen

$\varphi_{4}=\phi\left(\varphi_{3} ; d\right)=\phi\left(\phi\left(\varphi_{0} ; D\right) ; d\right)-2(p+1) \pi=\varphi_{0}-2(p+1) \pi \equiv \varphi_{0} \quad(\bmod 2 \pi)$,

vagyis a megoldás szögperiodikus $2 \pi$ modulussal.

2. Ha a (3.18) teljesül, akkor az elóbbihez hasonló számolás adja, hogy

$$
\begin{aligned}
& \varphi_{3}=\phi\left(\varphi_{0} ; D\right)-(2 p+1) \pi, \\
& \varphi_{4}=\varphi_{0}-(2 p+1) \pi \equiv \varphi_{0}-\pi \quad(\bmod 2 \pi),
\end{aligned}
$$

tehát a megoldás $4 \pi$ modulusú szögperiodikus.

Ha a $\varphi_{0}$-ra vonatkozó (3.16) kifejezést beírnánk a (3.17) vagy (3.18) összefüggésekbe, akkor azonnal adódna szükséges és elegendő föltétel a (3.13) egyenlet periodikus megoldásának létére. Ennél többet oldunk meg: az origóhoz közeledő, illetve attól távolodó megoldások létezésére keresünk olyan föltételeket, amelyek speciális eseteként előállnak a periodikus megoldások meglétét garantáló föltételek. Mivel a hintázás problémája áll témánk fókuszában, ezért elsôsorban az origótól távolodó megoldásokra vonatkozó gondolatokat fejtjük ki részletesen.

Tekintsük e célból a 3.11 ábra satírozott részének pontjait. Rögzítsünk egy $\gamma \in(0, \pi)$ számot és tekintsük a távolodó megoldások közül azokat, melyek $\left(\varphi_{0}, \varphi_{1}\right)$ pontjai az alábbi szakaszra esnek

$$
\text { (a) } \varphi_{1}=-\varphi_{0}-\gamma-j \pi \quad\left(0<\varphi_{0}<\frac{\pi}{2}-\frac{\gamma}{2} ; j \in \mathbb{N}\right)
$$

Rögzítsük $a_{1}$ és $\lambda>0$ értékét (azaz $T>0$ és $\varepsilon>0$ értékeit) a (3.13) rendszerben úgy, hogy $a_{1} \lambda L / \pi \notin \mathbb{Z}$. A (3.15) elsố egyenlóségéból látszik, hogy ekkor a (3.20) szakasz csak a $j=\left[a_{1} \lambda L / \pi\right]$ választással adhat origótól távolodó megoldást. Ekkor a pont abszcisszájára azt kapjuk, hogy

$$
\varphi_{0}=\left\{a_{1} \lambda \frac{L}{\pi}\right\} \frac{\pi}{2}-\frac{\gamma}{2}
$$

Elôször $2 \pi$ modulusú origótól távolodó megoldásokat keresünk, ezért a (3.21) kifejezést helyettesítsük be a (3.17)-ba. Ekkor

$$
\begin{aligned}
& \phi\left(\left\{a_{1} \lambda \frac{L}{\pi}\right\} \frac{\pi}{2}-\frac{\gamma}{2} ; D\right)-\phi\left(-\left\{a_{1} \lambda \frac{L}{\pi}\right\} \frac{\pi}{2}-\frac{\gamma}{2} ; D\right)+\left[a_{1} \lambda \frac{L}{\pi}\right] \pi= \\
& 2(p+1) \pi-a_{2} \lambda L .
\end{aligned}
$$

$\mathrm{Az}\left[a_{1} \lambda L / \pi\right]$ paritásától függóen két esetet tudunk megkülönböztetni. 
(1) $\left[a_{1} \lambda L / \pi\right]=2 m(m \in \mathbb{Z})$. Ekkor

$$
\begin{aligned}
\phi & \left(\left\{a_{1} \lambda \frac{L}{\pi}\right\} \frac{\pi}{2}-\frac{\gamma}{2} ; D\right)-\phi\left(-\left\{a_{1} \lambda \frac{L}{\pi}\right\} \frac{\pi}{2}-\frac{\gamma}{2} ; D\right)+\left[a_{1} \lambda \frac{L}{\pi}\right] \pi \\
& =\phi\left(\left\{a_{1} \lambda \frac{L}{\pi}\right\} \frac{\pi}{2}+2 m \frac{\pi}{2}-\frac{\gamma}{2} ; D\right)+\phi\left(\left\{a_{1} \lambda \frac{L}{\pi}\right\} \frac{\pi}{2}+2 m \frac{\pi}{2}+\frac{\gamma}{2} ; D\right)= \\
& =\phi\left(a_{1} \lambda \frac{L}{\pi} \frac{\pi}{2}-\frac{\gamma}{2} ; D\right)+\phi\left(a_{1} \lambda \frac{L}{\pi} \frac{\pi}{2}+\frac{\gamma}{2} ; D\right) .
\end{aligned}
$$

(2) $\left[a_{1} \lambda L / \pi\right]=2 m-1(m \in \mathbb{Z})$. Ebben az esetben a (3.22)-hez hasonló számolás végeredményeként a következô kifejezést kapjuk:

$$
\phi\left(\left(a_{1} \lambda \frac{L}{\pi} \frac{\pi}{2}-\frac{\gamma}{2}\right)+\frac{\pi}{2} ; D\right)+\phi\left(\left(a_{1} \lambda \frac{L}{\pi} \frac{\pi}{2}+\frac{\gamma}{2}\right)+\frac{\pi}{2} ; D\right)-\pi .
$$

Azt kaptuk tehát, hogy ha van egy a (3.20) szakaszhoz tartozó $2 \pi$ modulusú távolodó megoldás, akkor - bevezetve a $\mu:=a_{1} \lambda L / 2$ jelölést - teljesül a

$$
\frac{-\phi\left(\mu-\frac{\gamma}{2} ; D\right)-\phi\left(\mu+\frac{\gamma}{2} ; D\right)}{2}+(p+1) \pi=\frac{a_{2}}{a_{1}} \mu
$$

feltétel, amikor $\left[a_{1} \lambda L / \pi\right]$ páros, és a

$$
\begin{aligned}
& \frac{\left(-\phi\left(\left(\mu-\frac{\gamma}{2}\right)+\frac{\pi}{2} ; D\right)+\frac{\pi}{2}\right)+\left(-\phi\left(\left(\mu+\frac{\gamma}{2}\right)+\frac{\pi}{2} ; D\right)+\frac{\pi}{2}\right)}{2}+ \\
& (p+1) \pi=\frac{a_{2}}{a_{1}} \mu \quad \text { feltétel, amikor }\left[a_{1} \lambda L / \pi\right] \text { páratlan. }
\end{aligned}
$$

Ugyanezen számolásokat a

$$
\text { (b) } \varphi_{1}=-\varphi_{0}+\gamma-(j-1) \pi \quad\left(\frac{\pi}{2}+\frac{\gamma}{2}<\varphi_{0}<\pi ; j \in \mathbb{N}\right)
$$

szakaszra vonatkozóan elvégezve, a

$$
\varphi_{0}=\left(\left\{a_{1} \lambda \frac{L}{\pi}\right\}+1\right) \frac{\pi}{2}+\frac{\gamma}{2}
$$

kiinduló állapot választásával azt kapjuk, hogy ha van egy $2 \pi$ modulusú, a (3.25) szakaszhoz tartozó szögperiodikus megoldás, akkor a

$$
\begin{aligned}
\frac{\left(-\phi\left(\left(\mu-\frac{\gamma}{2}\right)+\frac{\pi}{2} ; D\right)+\frac{\pi}{2}\right)+\left(-\phi\left(\left(\mu+\frac{\gamma}{2}\right)+\frac{\pi}{2} ; D\right)+\frac{\pi}{2}\right)}{2}+ & (p+1) \pi=\frac{a_{2}}{a_{1}} \mu \quad \text { teljesül, ha }\left[a_{1} \lambda L / \pi\right] \text { páros, és a } \\
& \frac{-\phi\left(\mu-\frac{\gamma}{2} ; D\right)-\phi\left(\mu+\frac{\gamma}{2} ; D\right)}{2}+(p+1) \pi=\frac{a_{2}}{a_{1}} \mu
\end{aligned}
$$


teljesül, ha $\left[a_{1} \lambda L / \pi\right]$ páratlan.

Amennyiben periodikus megoldást keresünk, akkor a (3.23)-(3.24) és (3.26)(3.27) formulákban a $\gamma=0$ választással kell élnünk. Ezzel együtt, a periodikus megoldások föltérképezése során tekintetbe kell venni a

$$
\text { (c) } \varphi_{1}=\varphi_{0}-(j+1) \pi \quad\left(0 \leq \varphi_{0}<\pi ; j \in \mathbb{N}\right) \text {. }
$$

szakasz pontjait is. A (3.15) első egyenlőségébool adódik, hogy $a_{1} \lambda L / \pi=j+1$, azaz $a_{1} \lambda L / \pi \geq 1$ egész szám, és $\varphi_{0}$ tetszőleges, vagyis 3.11 lemmabeli (3.17) feltétel a következő alakot ölti:

$$
-\mu+(p+1) \pi=\frac{a_{2}}{a_{1}} \mu,
$$

amely egybeesik a (3.23)-(3.24), illetve a (3.26)-(3.27) föltételekkel a $\gamma=0$ választással.

Megfogalmazhatjuk tehát, hogy milyen föltételek mellett van $2 L$-periodikus megoldás.

3.12. Lemma. Legyen adott $a_{1}, a_{2}, \lambda$. A (3.13) rendszernek pontosan akkor van $2 L$-periodikus megoldása, ha vagy

$$
-\phi\left(a_{1} \lambda \frac{L}{2} ; \frac{a_{1}}{a_{2}}\right)+(p+1) \pi=a_{2} \lambda \frac{L}{2}
$$

vagy

$$
-\phi\left(a_{1} \lambda \frac{L}{2}+\frac{\pi}{2} ; \frac{a_{1}}{a_{2}}\right)+\frac{\pi}{2}+(p+1) \pi=a_{2} \lambda \frac{L}{2}
$$

valamely $p \in \mathbb{N}$ számra.

Bizonyítás. Szükségesség. A lemma kimondása előtt leírtakból világosan látszódik.

Elegendôség. Tegyük föl, hogy (3.28) teljesül. Ha $a_{1} \lambda L / \pi \notin \mathbb{Z}$ és $\left[a_{1} \lambda L / \pi\right]$ páros, akkor legyen

$$
\varphi_{0}=\left\{a_{1} \lambda \frac{L}{\pi}\right\} \frac{\pi}{2} .
$$

Azt kell megvizsgálnunk, hogy a $2 \pi$ modulusú szögperiodikus megoldást garantáló (3.17) kifejezés és a $f\left(\varphi_{1} ; D\right)=f\left(\varphi_{0} ; D\right)$ föltétel teljesül-e. A (3.28) 
formulából kiindulva a következőt írhatjuk

$$
\begin{aligned}
& \phi\left(\varphi_{0} ; D\right)-\phi\left(\varphi_{0}-a_{1} \lambda L ; D\right)=\phi\left(\left\{a_{1} \lambda \frac{L}{\pi}\right\} \frac{\pi}{2} ; D\right)- \\
& \phi\left(\left\{a_{1} \lambda \frac{L}{\pi}\right\} \frac{\pi}{2}-2 a_{1} \lambda \frac{L}{\pi} \frac{\pi}{2} ; D\right)=\left(\phi\left(a_{1} \lambda \frac{L}{2} ; D\right)-\left[a_{1} \lambda \frac{L}{\pi}\right] \frac{\pi}{2}\right)- \\
& \left(-\phi\left(a_{1} \lambda \frac{L}{2} ; D\right)-\left[a_{1} \lambda \frac{L}{\pi}\right] \frac{\pi}{2}\right)=2(p+1) \pi-a_{2} \lambda L,
\end{aligned}
$$

azaz a 3.11 lemmabeli (3.17) teljesül, ami azt jelenti, hogy a megoldás szögperiodikus $2 \pi$ modulussal. Másfelől, a (3.15) elsố egyenletéből

$$
\begin{aligned}
& \varphi_{1}=\varphi_{0}-a_{1} \lambda L=\left\{a_{1} \lambda \frac{L}{\pi}\right\} \frac{\pi}{2}-2 a_{1} \lambda \frac{L}{\pi} \frac{\pi}{2}=-\left\{a_{1} \lambda \frac{L}{\pi}\right\} \frac{\pi}{2}-\left[a_{1} \lambda \frac{L}{\pi}\right] \pi= \\
& -\varphi_{0}-\left[a_{1} \lambda \frac{L}{\pi}\right] \pi,
\end{aligned}
$$

tehát teljesül, hogy $f\left(\varphi_{1} ; D\right)=f\left(\varphi_{0} ; D\right)$, azaz a megoldás $2 L$-periodikus.

Ha $a_{1} \lambda L / \pi \notin \mathbb{Z}$ és $\left[a_{1} \lambda \frac{L}{\pi}\right]$ páratlan, akkor legyen

$$
\varphi_{0}=\left(\left\{a_{1} \lambda \frac{L}{\pi}\right\}+1\right) \frac{\pi}{2} .
$$

Az elôzố számoláshoz hasonlóan adódik, hogy

$$
\begin{aligned}
& \phi\left(\varphi_{0} ; D\right)-\phi\left(\varphi_{0}-a_{1} \lambda L ; D\right)=\phi\left(\left(\left\{a_{1} \lambda \frac{L}{\pi}\right\}+1\right) \frac{\pi}{2} ; D\right)- \\
& \phi\left(\left(\left\{a_{1} \lambda \frac{L}{\pi}\right\}+1\right) \frac{\pi}{2}-2 a_{1} \lambda \frac{L}{\pi} \frac{\pi}{2} ; D\right)=\phi\left(a_{1} \lambda \frac{L}{\pi} \frac{\pi}{2} ; D\right)- \\
& \left(\left[a_{1} \lambda \frac{L}{\pi}\right]-1\right) \frac{\pi}{2}+\phi\left(a_{1} \lambda \frac{L}{\pi} \frac{\pi}{2} ; D\right)+\left(\left[a_{1} \lambda \frac{L}{\pi}\right]-1\right) \frac{\pi}{2} \\
& =2(p+1) \pi-a_{2} \lambda L
\end{aligned}
$$

vagyis a megoldás szögperiodikus $2 \pi$ modulussal. Továbbá,

$$
\begin{aligned}
& \varphi_{1}=\varphi_{0}-a_{1} \lambda L=\left(\left\{a_{1} \lambda \frac{L}{\pi}\right\}+1\right) \frac{\pi}{2}-2 a_{1} \lambda \frac{L}{\pi} \frac{\pi}{2}=-\left\{a_{1} \lambda \frac{L}{\pi}\right\} \frac{\pi}{2}- \\
& \left(2\left[a_{1} \lambda \frac{L}{\pi}\right]-1\right) \frac{\pi}{2}=-\varphi_{0}-\left(\left[a_{1} \lambda \frac{L}{\pi}\right]-1\right) \pi,
\end{aligned}
$$

tehát a 3.11 és a 3.10 lemmák alapján a megoldás $2 L$-periodikus.

Végül, ha $a_{1} \lambda L / \pi \in \mathbb{Z}$, akkor $\varphi_{0}$ tetszőleges, és ekkor

$$
\phi\left(\varphi_{0} ; D\right)-\phi\left(\varphi_{0}-a_{1} \lambda L ; D\right)=a_{1} \lambda L=2(p+1) \pi-a_{2} \lambda L,
$$

így a megoldás $2 \pi$ modulusú szögperiodikus. Mivel

$$
f\left(\varphi_{1} ; D\right)=f\left(\varphi_{0}-a_{1} \lambda L ; D\right)=f\left(\varphi_{0} ; D\right),
$$


ezért a megoldás $2 L$-periodikus.

A (3.29) föltétel bizonyítása hasonló.

3.13. Lemma. Legyen adott $a_{1}, a_{2}, \lambda . A$ (3.13) rendszernek pontosan akkor van $4 L$-periodikus megoldása, ha vagy

$$
-\phi\left(a_{1} \lambda \frac{L}{2} ; D\right)+\left(p+\frac{1}{2}\right) \pi=a_{2} \lambda \frac{L}{2}
$$

vagy

$$
-\phi\left(a_{1} \lambda \frac{L}{2}+\frac{\pi}{2} ; D\right)+\frac{\pi}{2}+\left(p+\frac{1}{2}\right) \pi=a_{2} \lambda \frac{L}{2}
$$

valamely $p \in \mathbb{N}$ számra.

Bizonyítás. A $4 \pi$ modulusú esetben $\varphi_{4}=\varphi_{0}-(2 p+1) \pi$ föltevéssel élünk, amiból azt kapjuk, hogy $\varphi_{3}=\phi\left(\varphi_{0} ; D\right)-(2 p+1) \pi$. Tehát a $(3.17)$ és $(3.18)$ föltételekben $-(2 p+1)$ szerepel a $-2(p+1)$ helyett. Ezzel a változtatással a 3.12 lemma a 3.13 lemmabeli föltételeket adja.

Ezek alapján megfogalmazzuk az eredeti, (3.1) egyenlet periodikus megoldása létezését garantáló tételünket.

3.14. Tétel. Bármely $\varepsilon>0$ esetén van olyan $\left\{T_{k}(\varepsilon)\right\}_{k=1}^{\infty}$, illetve $\left\{\widetilde{T}_{k}(\varepsilon)\right\}_{k=1}^{\infty}$ sorozat, hogy a (3.1) egyenletnek a $T=T_{k}(\varepsilon)$ választással $2 T_{k}(\varepsilon)$-periodikus, illetve a $T=\widetilde{T}_{k}(\varepsilon)$ választással $4 \widetilde{T}_{k}(\varepsilon)$-periodikus megoldása van. Továbbá,

$$
0<\widetilde{T}_{1} \leq \widetilde{T}_{2}<T_{1} \leq T_{2}<\widetilde{T}_{3} \leq \widetilde{T}_{4}<\ldots ; \quad \lim _{k \rightarrow \infty} T_{k}=\infty
$$

és

$$
\begin{aligned}
& \lim _{\varepsilon \rightarrow 0+0} 2 T_{2 p+1}(\varepsilon)=\lim _{\varepsilon \rightarrow 0+0} 2 T_{2 p+2}(\varepsilon)=(2 p+2)\left(\frac{1}{2}\left(2 \pi \sqrt{\frac{l}{g}}\right)\right), \\
& \lim _{\varepsilon \rightarrow 0+0} 2 \widetilde{T}_{2 p+1}(\varepsilon)=\lim _{\varepsilon \rightarrow 0+0} 2 \widetilde{T}_{2 p+2}(\varepsilon)=(2 p+1)\left(\frac{1}{2}\left(2 \pi \sqrt{\frac{l}{g}}\right)\right)
\end{aligned}
$$

teljesül minden $p \in \mathbb{N}$ esetén.

Bizonyítás. A (3.1) egyenletnek pontosan akkor van $2 T$-, illetve $4 T$-periodikus megoldása, amikor a (3.13) rendszernek $2 L$-, illetve $4 L$-periodikus megoldása. 
Emiatt használhatjuk az előbb kimondott 3.12 és 3.13 lemmákat. Bevezetünk két kifejezést az áttekinthetóbb tárgyalás kedvéért.

$$
\begin{aligned}
& F_{p}(\mu):=-\phi(\mu ; D)+(p+1) \pi \\
& G_{p}(\mu):=\left(-\phi\left(\mu+\frac{\pi}{2} ; D\right)+\frac{\pi}{2}\right)+(p+1) \pi \quad(p \in \mathbb{N}),
\end{aligned}
$$

ahol $\mu:=a_{1} \lambda L / 2$. Bármely $p$ esetén az $F_{p}$ és a $G_{p}$ függvények szigorúan monoton csökkenők, így az $F_{p}(\mu)=\left(a_{2} / a_{1}\right) \mu$, és $G_{p}(\mu)=\left(a_{2} / a_{1}\right) \mu$ egyenleteknek pontosan egy megoldása van minden $((p+1) \pi / 2,(p+1) \pi)$ intervallumban (lásd a 3.12 ábrát); ezeket $\mu_{2 p+1} \leq \mu_{2 p+2}$ jelöli. Hasonlóan, az $F_{p}(\mu)-\pi / 2=\left(a_{2} / a_{1}\right) \mu$, és $G_{p}(\mu)-\pi / 2=\left(a_{2} / a_{1}\right) \mu$ egyenletek egyértelmú megoldásait jelölje $\widetilde{\mu}_{2 p+1} \leq$ $\tilde{\mu}_{2 p+2}$. Ekkor teljesül, hogy

$$
0<\widetilde{\mu}_{1}<\widetilde{\mu}_{2}<\mu_{1} \leq \mu_{2}<\widetilde{\mu}_{3} \leq \widetilde{\mu}_{4}<\mu_{3} \leq \mu_{4}<\ldots
$$

$\mathrm{Az} \varepsilon \rightarrow 0$ határátmenetet a (3.28)-(3.29) és a (3.30)-(3.31) kifejezésekben elvégezve kapjuk, hogy

$$
\begin{aligned}
\lim _{\varepsilon \rightarrow 0+0} \mu_{2 p+1}(\varepsilon) & =\lim _{\varepsilon \rightarrow 0+0} \mu_{2 p+2}(\varepsilon)=(p+1)\left(\frac{\pi}{2}\right), \\
\lim _{\varepsilon \rightarrow 0+0} \widetilde{\mu}_{2 p+1}(\varepsilon) & =\lim _{\varepsilon \rightarrow 0+0} \widetilde{\mu}_{2 p+2}(\varepsilon)=\left(p+\frac{1}{2}\right)\left(\frac{\pi}{2}\right) .
\end{aligned}
$$

A

$$
T_{k}(\varepsilon):=2 \sqrt{\frac{l-\varepsilon}{g}} \mu_{k}(\varepsilon), \quad \widetilde{T}_{k}(\varepsilon):=2 \sqrt{\frac{l-\varepsilon}{g}} \widetilde{\mu}_{k}(\varepsilon)
$$

választással a bizonyítás teljes.

A 3.14 tétel a klasszikus oszcillációs tétel [29] (3.13) rendszerre vonatkozó speciális esete. Azt mindenképp érdemes meggondolni, hogy miután mi megkonstruáltuk a periodikus megoldásokat, ezért az oszcillációs tételben megfogalmazott állításokat közvetlenül ezekből nyertük. A 3.12-3.13 lemmákból a (3.1) egyenlet periodikus megoldásainak egy másik nevezetes problémájára [22] is választ tudunk adni, tudniillik, amikor $\lambda$ kétszeres gyöke a karakterisztikus egyenletnek, és így az alaprendszert alkotó megoldásai mindketten periodikusak, s így minden megoldás periodikus. A (3.1) egyenletnek pontosan akkor van két, lineáris független $2 L$-periodikus, illetve $4 L$-periodikus megoldása, ha mind a (3.28), mind a (3.29), illetve mind a (3.30), mind a (3.31) teljesül ugyanarra a $p$-re és $\lambda$-ra. 


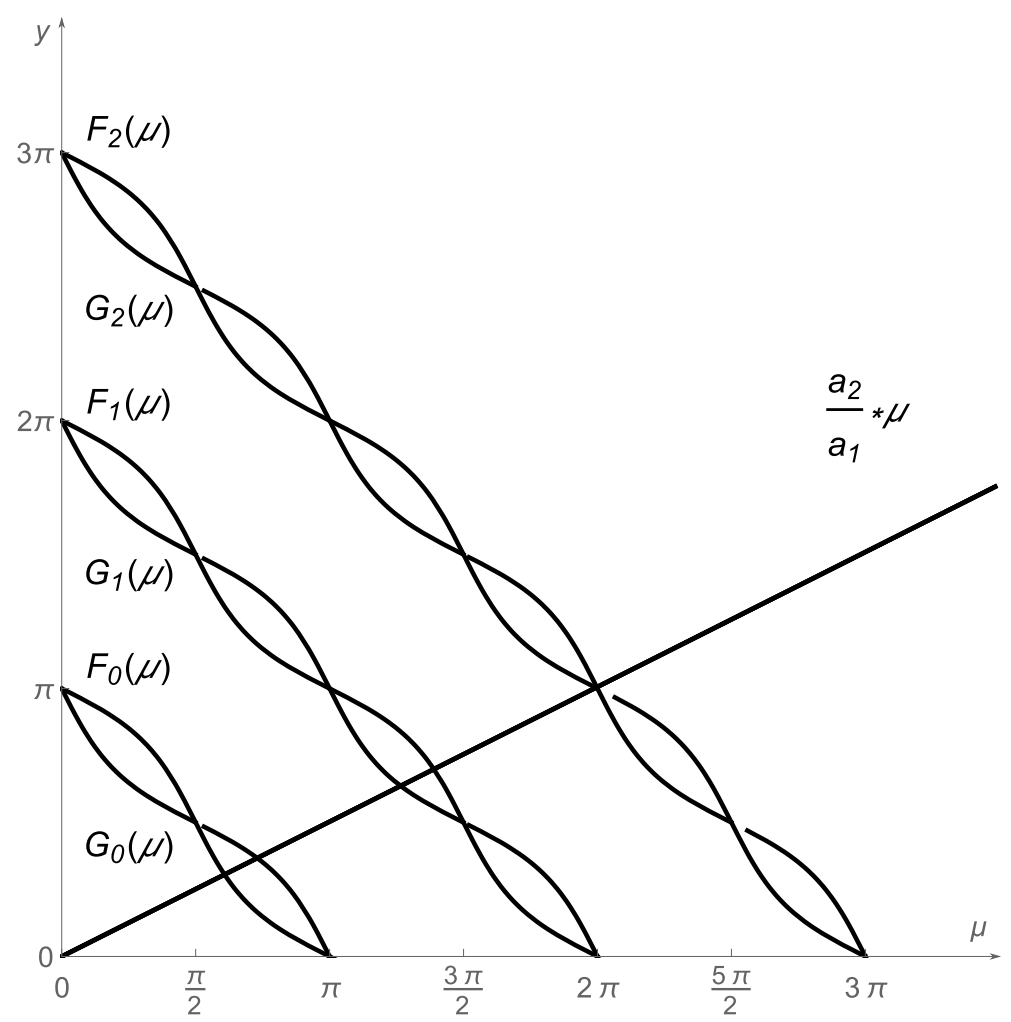

3.12. ábra. Az $F_{p}$ és a $G_{p}$ függvények grafikonjai $(l=2, \epsilon=1.2)$

3.15. Következmény. Legyen adott $T$ és $\varepsilon$. $H a a_{2} / a_{1}=\sqrt{(l-\varepsilon) /(l+\varepsilon)} r a$ cionális, azaz

$$
\sqrt{\frac{l-\varepsilon}{l+\varepsilon}}=\frac{m}{n} \quad(m, n \in \mathbb{N},(m, n)=1),
$$

akkor minden $\varepsilon>0$ esetén megszámlálható sok T létezik úgy, hogy (3.1) egyenlet minden megoldása vagy $2 T$-periodikus vagy $4 T$-periodikus. Még pontosabban, ha

$$
\sqrt{\frac{g}{l-\varepsilon}} \frac{T}{\pi}=j n \quad \text { és } \quad j(m+n) \text { páros }
$$

illetve

$$
\sqrt{\frac{g}{l-\varepsilon}} \frac{T}{\pi}=j n \quad \text { és } \quad j(m+n) \text { páratlan }
$$

valamely $j \in \mathbb{N}$ számra, akkor a (3.1) egyenlet összes megoldása $2 T$-periodikus, illetve $4 T$-periodikus.

A (3.20)-(3.27) számolásokból és a 3.12 lemma bizonyításában látottakból azonnal adódik az origótól távolodó megoldások létezésére vonatkozó állítás. 
3.16. Lemma. Legyen adva $a_{1}, a_{2}$ és $\lambda$. Ekkor a (3.13) rendszernek akkor és csakis akkor van $2 \pi$ modulusú szögperiodikus, origótól távolodó megoldása, ha van olyan $\gamma \in(0, \pi)$, hogy

$$
\frac{-\phi\left(\mu-\frac{\gamma}{2} ; D\right)-\phi\left(\mu+\frac{\gamma}{2} ; D\right)}{2}+(p+1) \pi=\frac{a_{2}}{a_{1}} \mu,
$$

vagy

$$
\frac{\left(-\phi\left(\left(\mu-\frac{\gamma}{2}\right)+\frac{\pi}{2} ; D\right)+\frac{\pi}{2}\right)+\left(-\phi\left(\left(\mu+\frac{\gamma}{2}\right)+\frac{\pi}{2} ; D\right)+\frac{\pi}{2}\right)}{2}+(p+1) \pi=
$$

valamely $p \in \mathbb{N}$ számra.

3.17. Lemma. Legyen adva $a_{1}, a_{2}$ és $\lambda$. Ekkor a (3.13) rendszernek akkor és csakis akkor van $4 \pi$ modulusú szögperiodikus, origótól távolodó megoldása, ha van olyan $\gamma \in(0, \pi)$, hogy

$$
\frac{-\phi\left(\mu-\frac{\gamma}{2} ; D\right)-\phi\left(\mu+\frac{\gamma}{2} ; D\right)}{2}+\left(p+\frac{1}{2}\right) \pi=\frac{a_{2}}{a_{1}} \mu,
$$

vagy

$$
\frac{\left(-\phi\left(\left(\mu-\frac{\gamma}{2}\right)+\frac{\pi}{2} ; D\right)+\frac{\pi}{2}\right)+\left(-\phi\left(\left(\mu+\frac{\gamma}{2}\right)+\frac{\pi}{2} ; D\right)+\frac{\pi}{2}\right)}{2}+\left(p+\frac{1}{2}\right) \pi=
$$

valamely $p \in \mathbb{N}$ számra.

Az origóhoz közeledő megoldások létezésére vonatkozó föltételeket a föntiekben részletesen kidolgozottak ismétlésével kaphatjuk azzal, hogy a 3.11 ábra nem satírozott részének pontjait kell tekintetbe vennünk. A számolások eredményeként a 3.16 - 3.17 lemmákban kimondottakkal megegyező föltételeket kapunk. Ez azt jelenti, hogy a (3.13) típusú egyenletek közül ugyanazoknak vannak közeledő és távolodó megoldásai.

\subsubsection{Stabilitási térkép}

Megmutatjuk, hogy az instabilitási tartomány megszámlálható sok komponensból áll (szokás ezeket Arnold-nyelveknek híni), majd meg is adjuk ezeket a 
komponenseket. Bevezetjük a következóket:

$$
H:=\cup_{p=0}^{\infty}\left(\mu_{2 p+1}, \mu_{2 p+2}\right), \quad \widetilde{H}:=\cup_{p=0}^{\infty}\left(\widetilde{\mu}_{2 p+1}, \widetilde{\mu}_{2 p+2}\right)
$$

(a $\mu_{j}, \widetilde{\mu}_{j}$ tekintetében lásd a (3.33)-at ).

3.18. Lemma. Minden $\mu \in H$, illetve $\mu \in \widetilde{H}$ esetén a (3.13) rendszernek van $2 \pi$, illetve $4 \pi$ modulusú szögperiodikus origótól távolodó megoldása.

Bizonyítás. A $2 \pi$ modulusú esetet írjuk le részletesen. Tekintsük egy tetszốleges, rögzített nemüres nyílt $\left(\mu_{2 p+1}, \mu_{2 p+2}\right)$ intervallumot. Tegyük föl, hogy

$$
2 m \frac{\pi}{2}<\mu_{2 p+1}<\mu_{2 p+2}<(2 m+1) \frac{\pi}{2} \quad(m \in \mathbb{N})
$$

ekkor

$$
F_{p}\left(\mu_{2 p+1}\right)=\frac{a_{2}}{a_{1}} \mu_{2 p+1}, \quad G_{p}\left(\mu_{2 p+2}\right)=\frac{a_{2}}{a_{1}} \mu_{2 p+2} .
$$

Ha $0<\gamma_{1}<\gamma_{2}<\pi$, akkor legyenek

$$
F_{p}^{\gamma}(\mu):=\frac{F_{p}\left(\mu-\frac{\gamma}{2}\right)+F_{p}\left(\mu+\frac{\gamma}{2}\right)}{2}, \quad G_{p}^{\gamma}(\mu):=\frac{G_{p}\left(\mu-\frac{\gamma}{2}\right)+G_{p}\left(\mu+\frac{\gamma}{2}\right)}{2} .
$$

Ezek a függvények kielégítik az

$$
F_{p}(\mu)<F_{p}^{\gamma_{1}}(\mu)<F_{p}^{\gamma_{2}}(\mu)<G_{p}(\mu), \quad F_{p}(\mu)<G_{p}^{\gamma_{2}}(\mu)<G_{p}^{\gamma_{1}}(\mu)<G_{p}(\mu)
$$

egyenlótlenségeket a $\left(\mu_{2 p+1}, \mu_{2 p+2}\right)$ intervallumon. Valóban, az $F_{p}$ függvény konvex, míg a $G_{p}$ függvény konkáv a $(2 m \pi / 2,(2 m+1) \pi / 2)$ intervallumban, tehát (3.34) kis $\gamma>0$ esetén teljesül. Nagyobb $\gamma$ esetén, amikor vagy $\mu-\gamma / 2$ vagy $\mu+\gamma / 2$, esetleg mindkettő ezen intervallumon kívülre esik, akkor (3.34) a $\phi$ függvény tulajdonságai miatt biztosan teljesül. Másrészról,

$$
\begin{gathered}
F_{p}^{0}(\mu) \equiv F_{p}(\mu), \quad G_{p}^{0} \equiv G_{p}(\mu), \\
\lim _{\gamma \rightarrow \pi-0} F_{p}^{\gamma}=G_{p}(\mu), \quad \lim _{\gamma \rightarrow \pi-0} G_{p}^{\gamma}(\mu)=F_{p}(\mu),
\end{gathered}
$$

s így a (3.34) bizonyítása teljes.

A (3.34)-ból következik, hogy bármely $\gamma \in(0, \pi)$ esetén az

$$
F_{p}^{\gamma}(\mu)=\frac{a_{2}}{a_{1}} \mu, \quad G_{p}^{\gamma}(\mu)=\frac{a_{2}}{a_{1}} \mu
$$




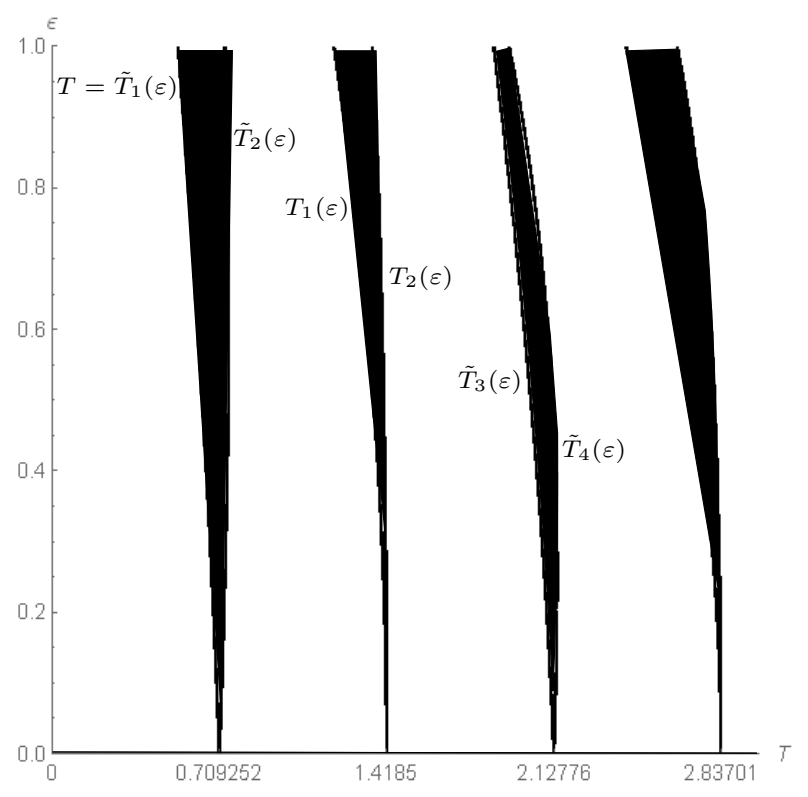

3.13. ábra. Arnold-nyelvek (a kép színezett zónái; $l=2$ )

egyenleteknek van megoldása a $\left(\mu_{2 p+1}, \mu_{2 p+2}\right)$ intervallumban, mialatt $\gamma 0$-tól $\pi$ ig változik. A 3.16 lemma alapján, minden (3.13) rendszernek van $2 \pi$ modulusú szögperiodikus, origótól távolodó megoldása, ha $a_{1} \lambda \pi / 2=\mu \in\left(\mu_{2 p+1}, \mu_{2 p+2}\right)$.

A $\widetilde{H}$ eset bizonyítása ugyanígy történik.

3.19. Tétel. A (3.1) egyenletre vonatkozó $(T, \varepsilon)$ paramétersík instabil tartományának belseje

$$
\begin{aligned}
& \cup_{0<\varepsilon<l}\left(\cup _ { p = 0 } ^ { \infty } \left(\left\{(T, \varepsilon): T_{2 p+1}(\varepsilon)<T<T_{2 p+2}(\varepsilon)\right\} \cup\right.\right. \\
& \left.\left.\left\{(T, \varepsilon): \widetilde{T}_{2 p+1}(\varepsilon)<T<\widetilde{T}_{2 p+2}(\varepsilon)\right\}\right)\right),
\end{aligned}
$$

ahol a $T_{k}, \widetilde{T}_{k}$ kifejezéseket a (3.32)-ben értelmeztük.

Bizonyítás. Az elôzoô alfejezet végén, illetve ezen alfejezet elején elmondottak alapján, továbbá a 3.14 tétel alapján mondhatjuk, hogy az instabil részhalmazok határaihoz tartoznak a $T_{k}$ és a $\widetilde{T}_{k}$ függvények grafikonjai. Másrészt, a 3.18 lemma alapján a (3.35) halmaz az instabilitási tartományhoz tartozik. Ezzel a bizonyítást befejeztük.

Sikerült tehát a hintázás problémáját megoldani úgy, hogy módszerünk amellett, hogy mellôzi a nehezen kezelhető Floquet-elméletet még konstruktív is. Az 
egy további kérdés, hogy a vizsgált modell írja-e le legjobban a hintázást. Erre vonatkozóan lásd a [18] dolgozatot. 


\section{4. fejezet}

\section{Fölsố egyensúlyi helyzet}

\section{stabilizálása}

Amint az Előszóban már említettük, az inga fölsố egyensúlyi helyzete stabilizálható olyan módon, hogy az inga fölfüggesztési pontját alkalmas frekvenciájú és amplitúdójú függóleges irányú rezgésbe hozzuk. Ezt a jelenséget számos dolgozat, például $[4,5,7,13,23,24,26,27,33,34,35]$, tárgyalja különbözô aspektusokból, mely publikációk eredményeit több földolgozásban, például [1, 8, 14, 32], is megtaláljuk. M. Levi és W. Weckesser a [28] cikkükben egy egyszerû geometriai hátterû magyarázatot adnak arra, hogy miként is lehetséges a stabilizálás nagy frekvencia esetén. Dolgozatukban olyan nagy frekvenciájú rezgést vizsgálnak, melynek során a gyorsulás lényegesen nagyobb a gravitációs gyorsulás értékénél, s emiatt ez utóbbit elhagyják. Ebben a fejezetben, miután bemutatjuk az általuk elért eredményt, rámutatunk arra, hogy a gravitáció hatásának figyelembe vételekor az általuk adott módszer nem múködik, emiatt azt módosítani kell. Tovább általánosítva az elgondolást, megvizsgáljuk, hogy a fölle rezgetés aszimmetriája hogyan jelentkezik a stabilizálhatóság tekintetében. 


\subsection{Levi és Weckesser módszere}

A [28] cikket követve, tegyük föl, hogy az inga fölfüggesztési pontjára olyan erő hat, melynek hatására létrejövő gyorsulás

$$
a(t):= \begin{cases}A, \text { ha } & k T \leq t<(2 k+1) \frac{T}{2}, \\ -A, \text { ha } & (2 k+1) \frac{T}{2} \leq t<(k+1) T, \quad(k=0,1, \ldots) .\end{cases}
$$

Tehát az $a(t)$ függvény egy $T$-periodikus lépcsôsfüggvény, melyet abban az értelemben mondunk szimmetrikusnak, hogy a fél-periódusok egyenlö hosszúak, és a fölvett függvényértékek egymás ellentettjei. A Bevezetésben fölírt (2.3) mozgásegyenletet ennek hatására a következóképp módosul:

$$
\ddot{\psi}-\frac{1}{l}(g+a(t)) \psi=0 .
$$

A továbbiakban a szerzők fölteszik, hogy $A>>g$, s emiatt a (4.2) egyenletben a gravitációs gyorsulást nem veszik figyelembe - úgynevezett gravitációmentes eset. Ahogyan a Bevezetésben említettük, a (4.2) egyenlet a (2.6) alakú rendszerré transzformálható. Bevezetve az $\omega=\sqrt{A / l}$ mennyiséget a (4.2) a következő, (2.3) egyenlethez hasonló formában írható:

$$
\ddot{\psi} \pm \omega^{2} \psi=0
$$

ahol az előjel az $a(t)$ függvénynek megfelelően változik. A Bevezetésben látott módon a (4.3) egyenletet vele ekvivalens rendszerbe lehet transzformálni. Ebból a célból vezessük be a két új változót:

$$
x=\psi, \quad y=\frac{\dot{\psi}}{\omega}
$$

Ezek segítségével a (4.3) az alábbi alakot ölti:

$$
\dot{x}=\omega y, \quad \dot{y}=\mp \omega x .
$$

A (4.5) tehát valójában két rendszerból áll. A $k T \leq t<(2 k+1) \frac{T}{2} \quad(k \in \mathbb{N})$ intervallumokon

$$
\dot{x}=\omega y, \quad \dot{y}=\omega x,
$$

míg a $(2 k+1) \frac{T}{2} \leq t<(k+1) T \quad(k \in \mathbb{N})$ intervallumokon

$$
\dot{x}=\omega y, \quad \dot{y}=-\omega x .
$$


Ahogyan a Bevezetésben bemutattuk, a (4.6) rendszer egy elsó integrálja a (2.8): $H_{h}(x, y)=x^{2}-y^{2}$, a (4.7) rendszeré pedig a $(2.7): H_{e}(x, y)=x^{2}+y^{2}$. A Bevezetésben leírtakhoz képesti különbség a fázispont mozgásában az, hogy mind a (4.6), mind a (4.7) rendszerben ugyanaz az együttható, azaz ebben a modellben nincs impulzív hatás: a fázispont nem szenved sem dilatációt, sem kontrakciót. Az elsô félperiódusban hiperbolán mozog, majd egy origó középpontú körön halad tovább. Ezt követôen újra egy hiperbolán megy, aztán újra egy origó középpontú köríven történő mozgást végez, s így tovább, lásd a 4.1 ábrát.

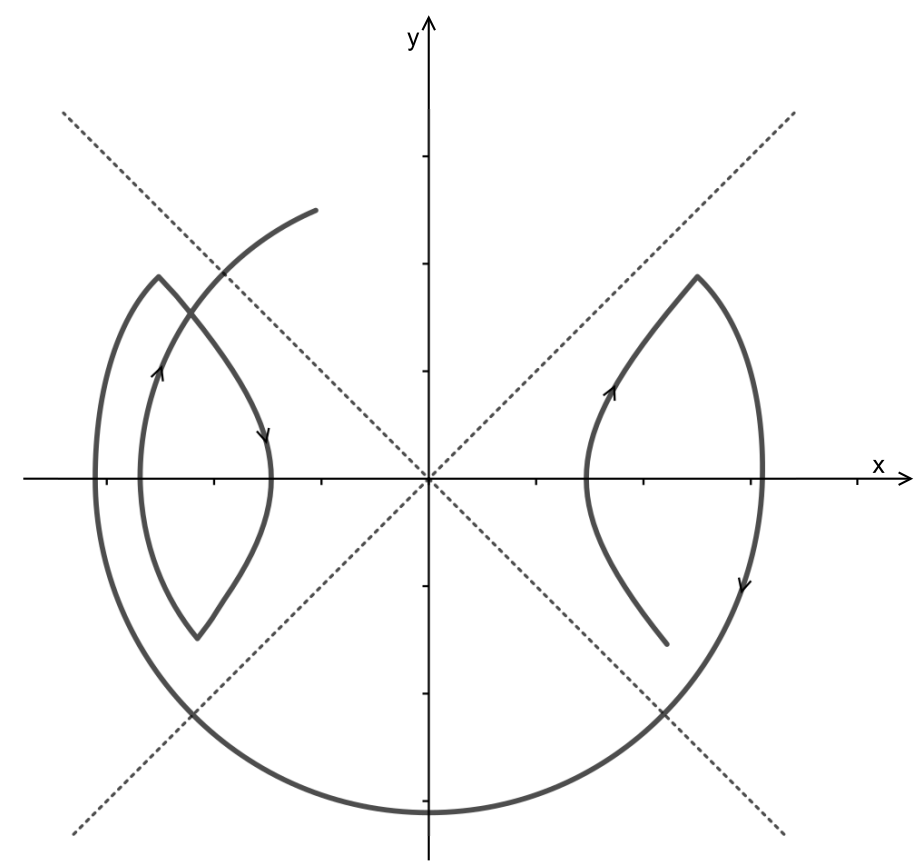

4.1. ábra. A fázispont mozgása gravitációmentes esetben

Az a geometriai észrevétel, amire a szerzők eredményüket alapozzák az elôzô fejezetben említett Floquet-elvre támaszkodik. Ahogyan ott láttuk, ennek használatához szükség van a rendszer monodrómia mátrixára. Ennek részletezésétôl terjedelmi okok miatt most eltekintünk, az érdeklődő olvasó az [1]-ben megtalálja. Az $M$ monodrómia $\operatorname{det} M=1$ tulajdonsága a (4.5) rendszerre vonatkozóan is teljesül. Ez a tulajdonság geometriailag azt jelenti, hogy az $M$ által reprezentált transzformáció területtartó. Egy ilyen mátrix erôs stabilitása ekvivalens azzal, hogy van olyan sajátértéke, mely nem valós szám. Ennek geometriai interpretációja, hogy egy erôsen stabil mátrix minden $\mathbb{R}^{2}$-beli vektort 
$\alpha \neq k \pi, k \in \mathbb{Z}$ szöggel forgat. Levi és szerzôtársa a monodrómiának mint két forgatásnak a hatását vizsgálta, becslést adva a hatásukra bekövetkező elfordulások szögeire, mely szögek összegére vonatkozóan az említett $\alpha \neq k \pi, k \in \mathbb{Z}$ feltételt figyelembe véve az alábbi következtetést vonták le.

4.1. Tétel (M. Levi, W. Weckesser; [28]). Tekintsük a fordított inga (4.2) mozgásegyenletét a gravitációmentes $(g=0)$ esetben. Ekkor ha

$$
\omega T<\pi \quad\left(\omega:=\sqrt{\frac{A}{l}}\right),
$$

akkor a (4.2) erôsen stabil.

Meglehetôsen természetes gondolatnak tartjuk a módszer kiterjesztését arra az esetre, amikor a gravitáció hatását is figyelembe vesszük. A következő fejezetben megmutatjuk, hogy erre van is lehetôség, továbbá, hogy így a 4.1 tétel eredménye is javítható. A következô alfejezet a [9] dolgozaton alapul.

\subsection{A Levi-Weckesser módszer kiterjesztése}

Az elôzố fejezetben bemutatott modell szerint az inga fölfüggesztési pontját egy szimmetrikus hatás érte: a létrejövố gyorsulás (4.1) egyenletben megadott alakú. Elhagyva ezt a szimmetriát és figyelembe véve a gravitáció hatását érdekes és a 4.1 tételben található eredménynél pontosabb becslést tudunk adni.

\subsubsection{Aszimmetrikusan rezgetett inga felső egyensúlyi hely- zetének stabilizálhatósága}

Tegyük föl tehát, hogy az $l$ hosszúságú inga fölfüggesztési pontját olyan függóleges irányú hatás éri, mely során létrejövố gyorsulás

$$
a(t):= \begin{cases}A_{h}, \text { ha } & k T \leq t<k T+T_{h}, \\ -A_{e}, \text { ha } & k T+T_{h} \leq t<\left(k T+T_{h}\right)+T_{e}, \\ (k=0,1, \ldots) & ;\end{cases}
$$

ahol $A_{h}, A_{e}, T_{h}, T_{e}$ pozitív konstansok $\left(T_{h}+T_{e}=T\right)$, tehát a felfüggesztési pont mozgása $T$-periodikus. A $h$ és $e$ indexek arra, az elôzményekből már sejthetô tényre utalnak, hogy két különböző fázisból áll össze a mozgás: egy elliptikus 
és egy hiperbolikus részból. Ennek részleteirôl az alábbiakban lesz szó. A (4.9) kifejezésben definiált gyorsulás hatására az inga fölfüggesztési pontja olyan mozgást végez, hogy a $p=p(t)$ függóleges irányú kitérés eleget tesz a következô két föltételnek:

$$
p(0)=0, \text { valamint } p(t+T) \equiv p(t)
$$

Induljunk el a $0 \leq t<T_{h}$ intervallumon. Ekkor $p^{\prime \prime}(t)=A_{h}$ és $p(0)=0, p^{\prime}(0)=$ $p_{0}^{\prime}$. Kétszeri integrálással kapjuk, hogy ekkor $p(t)=\frac{1}{2} A_{h} t^{2}+p_{0}^{\prime} t$. Ez azt is jelenti, hogy $p\left(T_{h}\right)=\frac{1}{2} A_{h} T_{h}^{2}+p_{0}^{\prime} T_{h}, p^{\prime}\left(T_{h}\right)=A_{h} T_{h}+p_{0}^{\prime}$.

A $T_{h} \leq t<T_{h}+T_{e}=T$ intervallumon $p^{\prime \prime}(t)=-A_{e}$. Ekkor $p^{\prime}(t)=p^{\prime}\left(T_{h}\right)-$ $A_{e}\left(t-T_{h}\right)$, és így $p(t)=p\left(T_{h}\right)+p^{\prime}\left(T_{h}\right)\left(t-T_{h}\right)-\frac{1}{2} A_{e}\left(t-T_{h}\right)^{2}$. A föltételekból kapjuk, hogy

$$
\begin{aligned}
& p(T)=p\left(T_{h}\right)+p^{\prime}\left(T_{h}\right) T_{e}-\frac{1}{2} A_{e} T_{e}^{2}=0 \\
& p^{\prime}(T)=p^{\prime}\left(T_{h}\right)-A_{e} T_{e}=p_{0}^{\prime}
\end{aligned}
$$

Fölhasználva a $p\left(T_{h}\right)$-ra és a $p^{\prime}\left(T_{h}\right)$-ra vonatkozó összefüggéseket, a második egyenletból adódik, hogy $A_{h} T_{h}=A_{e} T_{e}$. Ezt beírva az elsố egyenletbe, és kiküszöbölve $A_{e}$-t kapjuk, hogy $p_{0}^{\prime}=-\frac{1}{2} A_{h} T_{h}$. Most már meg tudjuk adni az inga fölfüggesztési pontjának kitérését az idő függvényében:

$$
p(t):= \begin{cases}\frac{1}{2} A_{h} t\left(t-T_{h}\right), \text { ha } & 0 \leq t<T_{h}, \\ -\frac{1}{2} A_{e}\left(t-T_{h}\right)^{2}+\frac{1}{2} A_{e} T_{e}\left(t-T_{h}\right), \text { ha } & T_{h} \leq t<T_{h}+T_{e}=T .\end{cases}
$$

A fölfüggesztési pont egy periódus, $T_{h}+T_{e}=T$, alatti kitéréseinek maximális értékeit, azaz amplitúdóit az elemi kalkulusból ismert módon, a (4.10) deriváltja segítségével tudjuk megadni:

$$
D_{h}=\frac{1}{8} A_{h} T_{h}^{2}, \quad D_{e}=\frac{1}{8} A_{e} T_{e}^{2} .
$$

Az imént fölírt hat paraméter között az alábbi összefüggéseket írhatjuk föl:

$$
\frac{A_{h}}{A_{e}}=\frac{T_{e}}{T_{h}}, \quad \frac{D_{h}}{D_{e}}=\frac{T_{h}}{T_{e}} .
$$

Hogy a mozgásegyenlet valóban (4.2) alakú, a rendszer Lagrange-függvényének segítségével megmutatható. Ennek fölírásához mindenek előtt állapodjunk meg abban, hogy az $(x, y)$ sík koordináta-tengelyei a szokásos irányításúak, továbbá, 


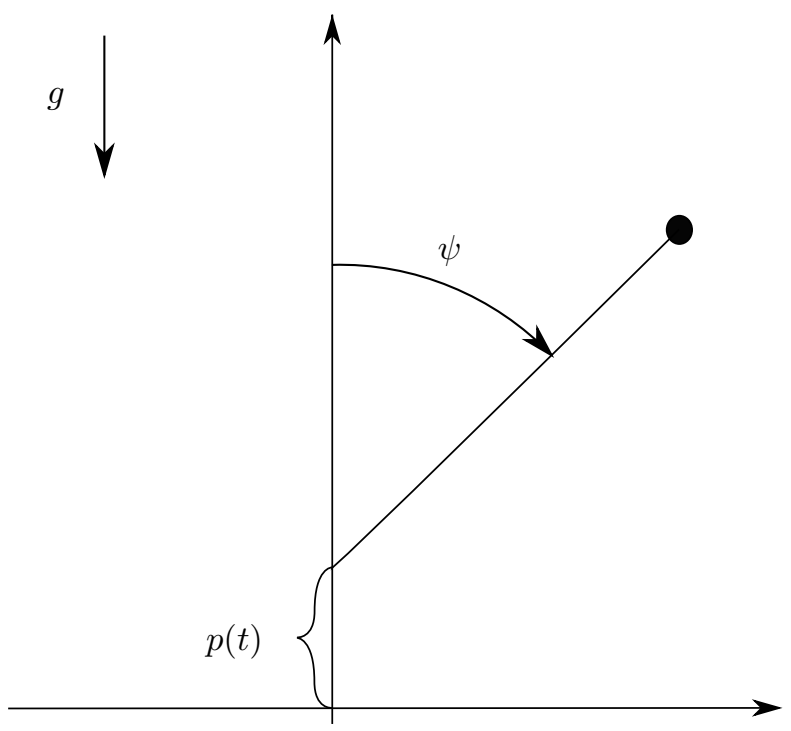

4.2. ábra. Kapica-inga

hogy a gravitáció iránya lefelé mutat, azaz negatív értékú. Ahogyan a Bevezetésben láttuk, az inga függóleges iránytól való kitérését mérô szög $(\psi)$ az óramutató járásával egyezô irányba nô, lásd a 4.2 ábrát.

Ekkor, az inga lengố végének koordinátáira:

$$
\begin{aligned}
& x=l \sin \psi \\
& y=l \cos \psi+p(t) .
\end{aligned}
$$

Így a sebességének megfelelő koordinátái:

$$
\begin{aligned}
& \dot{x}=l \dot{\psi} \cos \psi \\
& \dot{y}=-l \dot{\psi} \sin \psi+\dot{p}(t) .
\end{aligned}
$$

A kinetikai energiára és a potenciálra ezek után a következốt kapjuk:

$$
\begin{aligned}
T & =\frac{1}{2} m\left(l^{2} \dot{\psi}^{2} \cos ^{2} x+l^{2} \dot{\psi}^{2} \sin ^{2} x+\dot{p}^{2}-2 l \dot{\psi} \dot{p} \sin \psi\right) \\
V & =m g(l \cos \psi+p(t)) .
\end{aligned}
$$

Az $m$ a végpont tömegét jelenti. A keresett Lagrange-függvény így:

$$
L=T-V=\frac{1}{2} m\left(l^{2} \dot{\psi}^{2}+\dot{p}^{2}-2 l \dot{\psi} \dot{p} \sin \psi\right)-m g(l \cos \psi+p(t)) .
$$

Kiszámítva a $\partial L / \partial \dot{\psi}, \partial L / \partial \psi$ és a $\frac{d}{d t} \partial L / \partial \dot{\psi}$ deriváltakat, az Euler-Lagrangeegyenlet a következő alakú:

$$
l^{2} \ddot{\psi}-(g+\ddot{p}) l \sin \psi=0 .
$$


Kihasználva azt, hogy $\ddot{p}(t)=a(t)$, és a lineáris közelítést alkalmazva kapjuk, hogy

$$
\ddot{\psi}-\frac{1}{l}(g+a(t)) \psi=0
$$

Fölírtuk tehát az inga fölső egyensúlyi helyzete körüli kis lengések egyenletét. Az $a(t)$ függvény értékeinek megfelelôen a (4.13) alapegyenletet az alábbi módon írhatjuk:

$$
\ddot{\psi}-\frac{1}{l}\left(g+A_{h}\right) \psi=0, \text { ha } k T \leq t<k T+T_{h},
$$

illetve

$$
\ddot{\psi}-\frac{1}{l}\left(g-A_{e}\right) \psi=0, \text { ha } k T+T_{h} \leq t<\left(k T+T_{h}\right)+T_{e}
$$

Mivel $A_{h}>0$, ezért a (4.14) egyenlettel adott mozgás (pontosabban szólva a $\psi=0$ egyensúlyi helyzet) mindenképpen instabil, hiszen azt fejezi ki, hogy az erő - ami Newton 2. axiómájának megfelelően arányos a $\ddot{\psi}$ gyorsulással - iránya a kitérés irányába $(\psi)$ mutat, és annak értékét növeli. Vegyük észre, hogy a (4.15) egyenlet ugyanezt jelenti, ha az $A_{e}$ értéke nem nagyobb, mint a $g$ értéke. Ez utóbbi esetben természetesen egyértelmúen ki lehet jelenteni, hogy hiába rezegtetjük az inga fölfüggesztési pontját föl-le, a $\psi=0$ egyensúlyi helyzet instabil.

A feladat éppen abban áll, hogy keressünk olyan $A_{e}$ értéket, és így a föntebb bemutatott összefüggések alapján, olyan $T_{e}$, illetve $T_{h}$ értékeket, hogy a (4.15) egyenletben a $g-A_{e}$ együttható legyen negatív, sốt, a $T_{h}+T_{e}=T$ idô alatt ez a stabilizáló hatás érvényesüljön. Mindezekból következik, hogy az $A_{e}>g$ egy szükséges föltételt jelent.

Ezek után, a két különbözô fázisnak megfelelően két különbözô sajátfrekvenciát vezetünk be

$$
\omega_{h}:=\sqrt{\frac{A_{h}+g}{l}}, \quad \omega_{e}:=\sqrt{\frac{A_{e}-g}{l}},
$$

s így a (4.13) egyenlet a

$$
\ddot{\psi}-\omega_{h}^{2} \psi=0 \quad\left(k T \leq t<k T+T_{h}\right)
$$

és

$$
\ddot{\psi}+\omega_{e}^{2} \psi=0 \quad\left(k T+T_{h} \leq t<\left(k T+T_{h}\right)+T_{e}\right),
$$


esetekre bontható. Tekintsük a (4.17) hiperbolikus esetet. A (4.4)-ben bevezetett $x_{h}=\psi, y_{h}=\dot{\psi} / \omega_{h}$ új változókkal a (4.17) az alábbi rendszerrel lesz ekvivalens:

$$
\dot{x}_{h}=\omega_{h} y_{h}, \quad \dot{y}_{h}=\omega_{h} x_{h} .
$$

Polárkoordinátákat $\left(r_{h}, \varphi_{h}\right)$ és az

$$
x_{h}=r_{h} \cos \varphi_{h}, \quad y_{h}=r_{h} \sin \varphi_{h} \quad\left(r_{h}>0,-\infty<\varphi_{h}<\infty\right)
$$

transzformációs szabályokat fölhasználva a (4.17) egyenletet a következô rendszerbe írhatjuk át

$$
\dot{r}_{h}=r_{h} \omega_{h} \sin 2 \varphi_{h}, \quad \dot{\varphi}_{h}=\omega_{h} \cos 2 \varphi_{h} .
$$

A $H_{h}(x, y):=x_{h}^{2}-y_{h}^{2}$ a (4.19) egy elsô integrálja, amint arról meggyôzôdhetünk, ha kiszámítjuk ennek az úgynevezett rendszer szerinti deriváltját: $\dot{H}_{h}=2 x_{h} \dot{x}_{h}-$ $2 y_{h} \dot{y}_{h}=2 x_{h} \omega_{h} y_{h}-2 y_{h} \omega_{h} x_{h}=0$. Tehát, a trajektóriák, amint azt már tudjuk, hiperbola-ívek.

A (4.18) rendszert az előzóhöz hasonló módon tudjuk kezelni. Ebben a fázisban az új változók

$$
x_{e}=\psi, \quad y_{e}=\frac{\dot{\psi}}{\omega_{e}} .
$$

Ezekkel a következô rendszert kapjuk:

$$
\dot{x}_{e}=\omega_{e} y_{e}, \quad \dot{y}_{e}=-\omega_{e} x_{e},
$$

mely polárkoordinátákkal fölírva:

$$
\dot{r}_{e}=0, \quad \dot{\varphi}_{e}=-\omega_{e}
$$

A $H_{e}(x, y):=x_{e}^{2}+y_{e}^{2}$ a (4.21) egy elsó integrálja, tehát a fázisgörbék origó középpontú körívek. Vegyük észre, hogy a Levi-Weckesser módszer ismertetése során leírtakhoz képest most merôben más helyzettel állunk szemben. A különbség, hogy a hiperbolikus és elliptikus fázis között a Bevezetésben említett impulzív effektus történik. A $[0, T]$ intervallumon a $t=T_{h}$ és a $t=T$ pillanatokban rendre egy $\omega_{h} / \omega_{e}$, illetve egy $\omega_{e} / \omega_{h}$ mértékú „ugrás" történik az y-tengellyel párhuzamosan, lásd a 4.3 ábrát.

Követve a [28] cikkben található eljárást, becsléseket adunk a hiperbolikus és elliptikus forgatások szögeire, illetve az impulzív hatásra bekövetkezô szögváltozásra. Tekintsük a (4.20) második egyenletét, mely szeparábilis, így integrálható. 


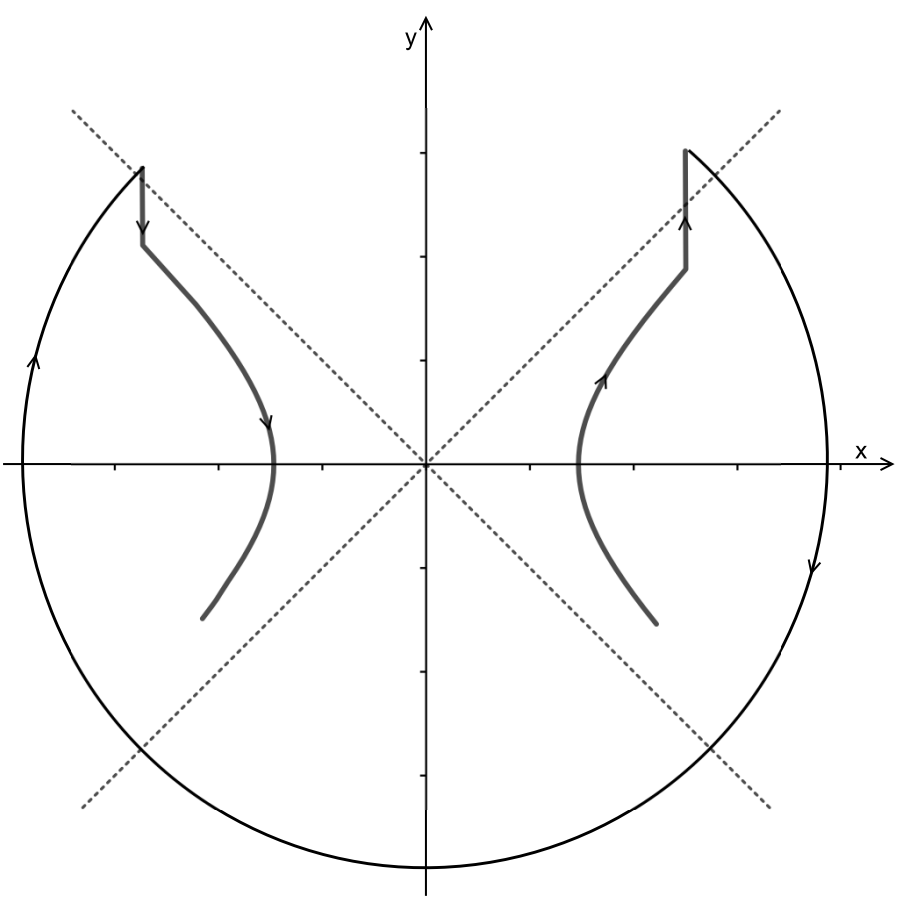

4.3. ábra. A fordított inga fázistere $\omega_{h}>\omega_{e}$ esetén

Ha $\cos 2 \varphi_{h}(0)=0$, akkor

$$
\cos 2 \varphi_{h}(t) \equiv 0\left(t \in\left[0, T_{h}\right)\right),
$$

vagyis az $\left(r_{h}(0), \varphi_{h}(0)\right)$ fázispont nem fordul el. Ha $\cos 2 \varphi_{h}(0) \neq 0$, akkor

$$
\int_{0}^{T_{h}} \frac{\dot{\varphi}_{h}(t)}{\cos 2 \varphi_{h}(t)} d t=\int_{\varphi_{h}(0)}^{\varphi_{h}\left(T_{h}-0\right)} \frac{d \tau}{\cos 2 \tau}=\omega_{h} T_{h} .
$$

Legyen

$$
G(\varphi):=\int_{0}^{\varphi} \frac{d \tau}{\cos 2 \tau}
$$

Ha $-\pi / 4<\varphi<\pi / 4$, akkor $G(\varphi)=\ln \sqrt{\frac{1+\tan \varphi}{1-\tan \varphi}}$. A $G$ függvény invertálható, inverzét jelölje $G^{-1}$, melynek grafikonja a 4.4 ábrán látható. A $G$ és a $G^{-1}$ függvények segítségével a (4.23) egyenletból kapjuk, hogy

$$
\varphi_{h}\left(T_{h}-0\right)=G^{-1}\left[\omega_{h} T_{h}+G\left(\varphi_{h}(0)\right)\right]
$$

vagyis

$$
\varphi_{h}\left(T_{h}-0\right)=\arctan \frac{e^{2 \omega_{h} T_{h}} \frac{1+\tan \varphi_{h}(0)}{1-\tan \varphi_{h}(0)}-1}{e^{2 \omega_{h} T_{h}} \frac{1+\tan \varphi_{h}(0)}{1-\tan \varphi_{h}(0)}+1} .
$$




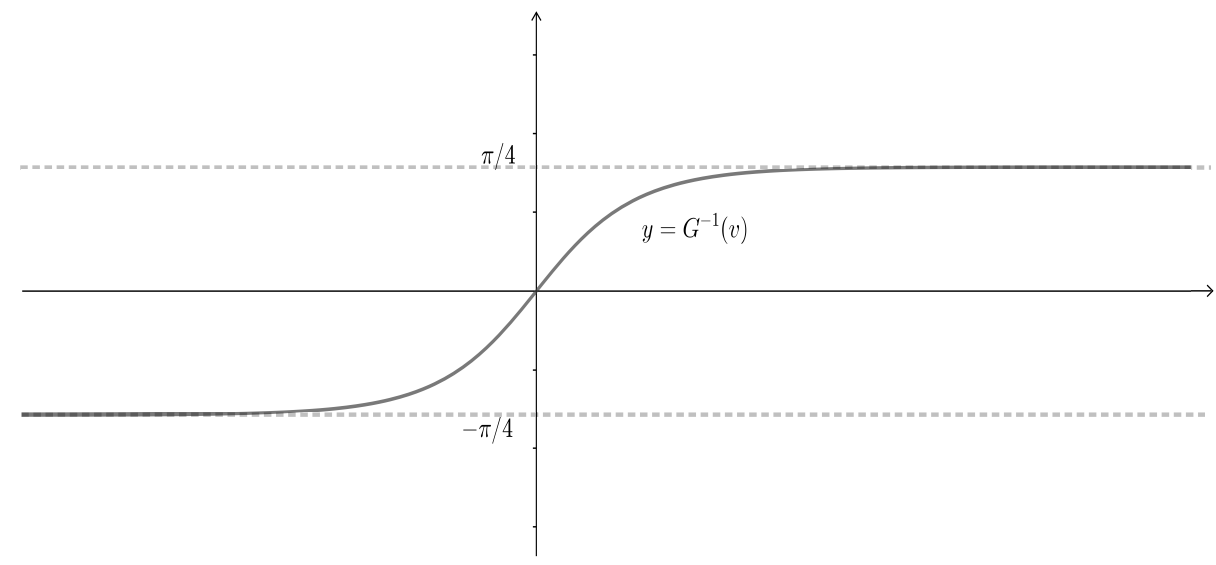

4.4. ábra. A $G^{-1}$ függvény grafikonja

A $\left|\varphi_{h}\left(T_{h}-0\right)-\varphi_{h}(0)\right|$ becslése során kihasználjuk, hogy $G^{-1}$ páratlan, és konkáv a $[0, \infty]$ félegyenesen. Föltesszük továbbá, hogy $\left|\varphi_{h}(0)\right|<\pi / 4$. A $G^{-1}$ függvény grafikonjáról könnyen látható, hogy a megbecsülni kívánt szögérték akkor lesz maximális, ha a $T_{h}$ hosszú intervallum szimmetrikusan illeszkedik az origóra. $\mathrm{Az}$ is észrevehető, hogy a $\varphi_{h}(0)=0$ választás mellett várható a legnagyobb mértékü forgatás. Ezek alapján írhatjuk, hogy

$$
\max _{-\pi / 4 \leq \varphi_{h}(0) \leq \pi / 4}\left|\varphi_{h}\left(T_{h}-0\right)-\varphi_{h}(0)\right|=2 \arctan \frac{e^{\omega_{h} T_{h}}-1}{e^{\omega_{h} T_{h}}+1},
$$

azaz meg tudtuk adni a kívánt fölsố becslést a hiperbolikus forgatás során bekövetkező elfordulás szögére.

A (4.22) második egyenlete által megadott elliptikus forgatás hatására bekövetkező elfordulás szögét pontosan meg tudjuk adni:

$$
\varphi_{e}\left(T_{h}+T_{e}-0\right)-\varphi_{e}\left(T_{h}\right)=-\omega_{e} T_{e}
$$

Az impulzív effektus hatására bekövetkezô szögváltozás mértékére, azaz a

$$
\varphi_{e}\left(T_{h}\right)-\varphi_{h}\left(T_{h}-0\right), \quad \varphi_{h}\left(T_{h}+T_{e}\right)-\varphi_{e}\left(T_{h}+T_{e}-0\right)
$$

forgások mértékére adott becslés van még hátra. A hiperbolikus és elliptikus fázisok végén jelentkező „ugrások" az $(x, y)$ ponton egy $y$-tengely irányú lineáris transzformációt jelentenek:

$$
(x, y) \mapsto(x, q y)=:(x, \hat{y}) \quad(0<q=\text { const. }, q \neq 1)
$$




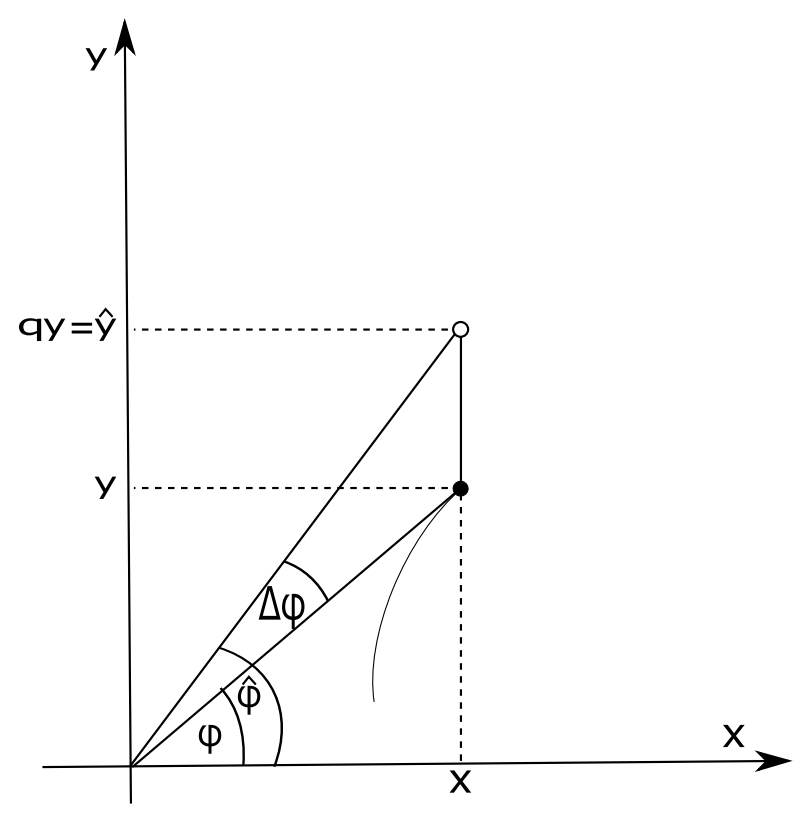

4.5. ábra. Egy ugrás során bekövetkező szögváltozás

lásd a 4.5 ábrát.

Ha $\varphi \in(-\pi / 2, \pi / 2)$, akkor $\hat{\varphi} \in(-\pi / 2, \pi / 2)$, ahol $\hat{\varphi}$ az $(x, \hat{y})$ pont polárszögét jelöli, és

$$
\begin{aligned}
f_{q}(\varphi):=\Delta \varphi & =\hat{\varphi}-\varphi=\arctan \left(q \frac{y}{x}\right)-\arctan \frac{y}{x} \\
& =\arctan (q \tan \varphi)-\varphi ; \\
f_{q}^{\prime}(\varphi) & =q \frac{1+\tan ^{2} \varphi}{1+q^{2} \tan ^{2} \varphi}-1 .
\end{aligned}
$$

Elemi analízisből tudjuk, hogy a szélsőérték szükséges föltétele, hogy $f_{q}^{\prime}(\varphi)=0$ teljesüljön. Ezt kiszámítva kapjuk, hogy

$$
\max _{-\pi / 2<\varphi<\pi / 2}\left|f_{q}(\varphi)\right|=\left|\arctan \sqrt{q}-\arctan \frac{1}{\sqrt{q}}\right| .
$$

Ugyanez a becslés érvényes akkor is, amikor $\varphi \in(\pi / 2,3 \pi / 2)$, és így

$$
\max _{0 \leq \varphi \leq 2 \pi}|\Delta \varphi| \leq\left|\arctan \sqrt{q}-\arctan \frac{1}{\sqrt{q}}\right| .
$$

$\mathrm{Az}$

$$
\arctan x-\arctan \frac{1}{x}=2 \arctan x-\frac{\pi}{2} \quad(x>0) ;
$$

összefüggés fölhasználásával kapjuk, hogy

$$
\max _{0 \leq \varphi \leq 2 \pi}|\Delta \varphi| \leq 2\left|\arctan \sqrt{q}-\frac{\pi}{4}\right| .
$$


Megjegyzés. Az impulzív effektus, egyszerủen szólva ugrás, az eltérô fázisok ((4.19) és (4.21)) közötti átmenet leírására szolgáló matematikai eszköz. Ezen ugrások mértékét a következóképp tudjuk kifejezni:

$$
q-1=\frac{\omega_{h}}{\omega_{e}}-1=\frac{\left(A_{h}-A_{e}\right)+2 g}{\sqrt{\left(A_{e}-g\right)\left(A_{h}+g\right)}+\left(A_{e}-g\right)},
$$

vagyis ez a szimmetrikus és gravitációmentes esettôl való eltérést méri (épp a Levi és Weckesser által tárgyalt eset). Amennyiben a rezgetés szimmetrikus $\left(A_{h}=A_{e}=A\right)$, akkor

$$
q-1=\frac{g}{A}+o\left(\frac{g}{A}\right) \quad(A \rightarrow \infty)
$$

aszimptotikusan a $g$ és $A$ gyorsulások arányával egyenló.

\subsubsection{Eredmények}

Alkalmazva az általunk kiszámított becsléseket, olyan inga fölső egyensúlyi helyzetének stabilizálhatóságára kapunk elegendő föltételt, melynek fölfüggesztési pontját függóleges irányban aszimmetrikus módon rezegtetjük és a gravitáció hatását is fegyelembe vesszük.

4.2. Tétel. Jelölje $\operatorname{Rem}(\varphi ; \pi)$ a $\varphi \in \mathbb{R}$ valós szám osztási maradékát moduló $\pi$ $(0 \leq \operatorname{Rem}(\varphi ; \pi)<\pi)$.

$H a$

$$
\begin{aligned}
& 2 \arctan \frac{e^{\omega_{h} T_{h}}-1}{e^{\omega_{h} T_{h}}+1}+4\left|\arctan \sqrt{\frac{\omega_{h}}{\omega_{e}}}-\frac{\pi}{4}\right| \\
& <\min \left\{\operatorname{Rem}\left(\omega_{e} T_{e} ; \pi\right) ; \pi-\operatorname{Rem}\left(\omega_{e} T_{e} ; \pi\right)\right\},
\end{aligned}
$$

akkor a (4.13) egyenlet erốsen stabil.

Bizonyítás. Jelölje $R_{h}\left(\omega_{h}, T_{h}\right)$, illetve $R_{e}\left(\omega_{e}, T_{e}\right)$ rendre a (4.19), illetve (4.21) által meghatározott

$$
\left(x_{h}(0), y_{h}(0)\right) \mapsto\left(x_{h}\left(T_{h}-0\right), y_{h}\left(T_{h}-0\right)\right),
$$

illetve

$$
\left(x_{e}\left(T_{h}\right), y_{e}\left(T_{h}\right)\right) \mapsto\left(x_{e}\left(T_{h}+T_{e}-0\right), y_{e}\left(T_{h}+T_{e}-0\right)\right)
$$

forgatások mátrixait, továbbá vezessük be a következő jelölést

$$
C(\lambda)=\left(\begin{array}{cc}
1 & 0 \\
0 & \lambda
\end{array}\right) \quad(\lambda>0, \lambda \neq 1) .
$$


Így a rendszer $M$ monodrómia mátrixát a következó szorzattal adhatjuk meg:

$$
\begin{aligned}
M= & C^{-1}\left(\frac{1}{\omega_{e}}\right) R_{e}\left(\omega_{e}, T_{e}\right) C\left(\frac{1}{\omega_{e}}\right) C^{-1}\left(\frac{1}{\omega_{h}}\right) \\
& \times R_{h}\left(\omega_{h}, T_{h}\right) C\left(\frac{1}{\omega_{h}}\right) \\
= & C^{-1}\left(\frac{1}{\omega_{h}}\right) C\left(\frac{\omega_{e}}{\omega_{h}}\right) R_{e}\left(\omega_{e}, T_{e}\right) C\left(\frac{\omega_{h}}{\omega_{e}}\right) \\
& \times R_{h}\left(\omega_{h}, T_{h}\right) C\left(\frac{1}{\omega_{h}}\right)=C^{-1}\left(\frac{1}{\omega_{h}}\right) \tilde{M} C\left(\frac{1}{\omega_{h}}\right) .
\end{aligned}
$$

Mivel az $\left(M^{k}\right)_{k \in \mathbb{Z}}$ pontosan akkor korlátos, ha $\left(\tilde{M}^{k}\right)_{k \in \mathbb{Z}}$ korlátos, ezért elegendő megmutatni, hogy $\tilde{M}$ mátrixnak nincs valós sajátértéke, azaz $\tilde{M}$ minden nemnulla $\mathbb{R}^{2}$-beli vektort $(\bmod \pi)$ nemnulla szöggel forgat. Az $R_{e}\left(\omega_{e}, T_{e}\right)$ minden vektort pontosan $-\omega_{e} T_{e}$ szöggel forgat (lásd (4.22)), továbbá az $R_{h}\left(\omega_{h}, T_{h}\right)$, $C\left(\frac{\omega_{h}}{\omega_{e}}\right)$, valamint $C\left(\frac{\omega_{e}}{\omega_{h}}\right)$ hatására bekövetkezó szögelfordulásra (4.24) és (4.25) kifejezésekkel adott becslések alapján mondhatjuk, hogy a (4.26) feltétel garantálja, hogy $\tilde{M}$ minden $\mathbb{R}^{2}$-beli vektort 0 -tól különbözô szöggel forgat $(\bmod \pi)$.

Annak érdekében, hogy összehasonlítsuk a 4.1 tételben adott (4.8) feltételt a (4.26) föltétellel, alkalmazzuk a 4.2 tételt a gravitációmentes és szimmetrikus esetre. Ekkor a következôt kapjuk.

4.3. Következmény. Tegyük föl, hogy a (4.13) egyenletben $g=0$, valamint $A_{h}=A_{e}=A$. Ha

$$
\begin{aligned}
& 4 \arctan \frac{e^{\omega T / 2}-1}{e^{\omega T / 2}+1}< \\
& <\min \{\operatorname{Rem}(\omega T ; 2 \pi) ; 2 \pi-\operatorname{Rem}(\omega T ; 2 \pi)\},
\end{aligned}
$$

akkor (4.13) erôsen stabil.

Kétségtelen, hogy a (4.27) kifejezés komplikáltabb, mint a Levi-Weckesser szerzôpáros által a 4.1 tételben megadott (4.8) föltétel. Ugyanakkor a 4.3 következmény lényegesen javítja 4.1 tételt. Valóban, először is

$$
4 \arctan \frac{e^{\omega T / 2}-1}{e^{\omega T / 2}+1}<\omega T \quad(0<\omega T<\pi),
$$

vagyis az elsố olyan intervallum, amibe stabil megoldásoknak megfelelô pontok vannak az $\omega T$-tengelyen, kielégítve a (4.27) feltételt, a $(0,3,75 \ldots)$ (lásd a 4.6 


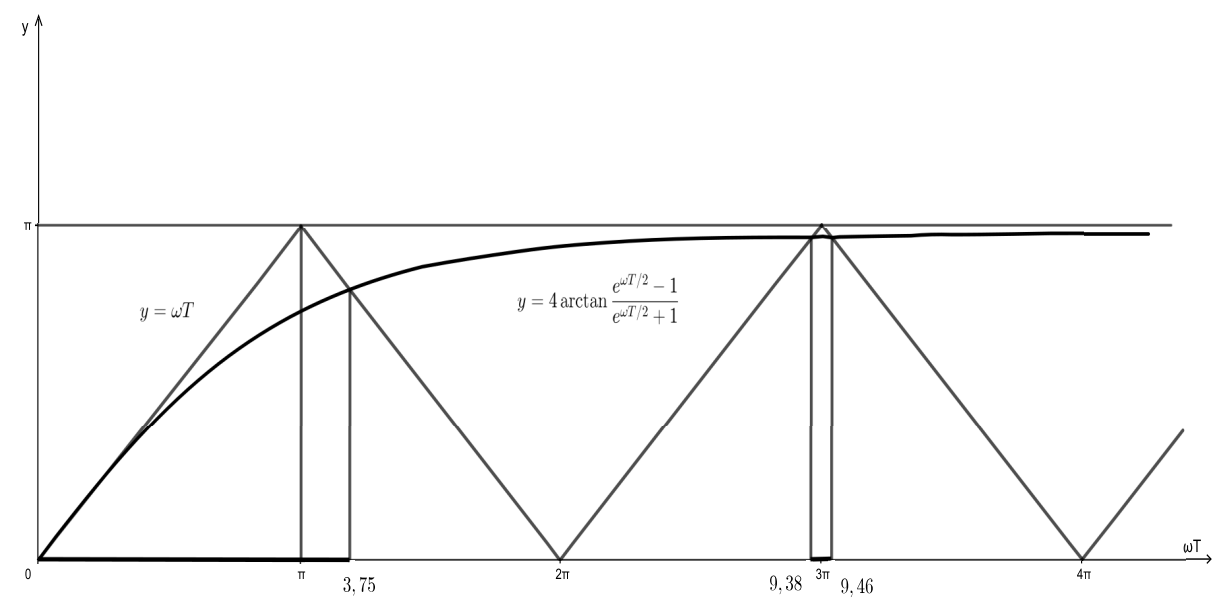

4.6. ábra. Stabil intervallumok

ábrát) a $(0, \pi)$ helyett, amit a (4.8) alapján eddig tudtunk. Másfelól pedig, a 4.3 következmény a 4.1 tételt abban az értelemben is javítja, ha úgy tetszik kiterjeszti, hogy további stabil intervallumokat találhatunk az $\omega T$-tengelyen a $2 \pi$ után is (lásd a vastagított intervallumot a 4.6 ábrán). Azt mondhatjuk tehát, hogy tetszólegesen nagy $\omega T=T \sqrt{A / l}$ esetén lehetséges a stabilizálás. Erre a (4.8) feltételból nem lehet következtetni.

A szimmetrikus esetet $\left(A_{h}=A_{e}=A, T_{h}=T_{e}=T / 2\right)$ Arnold is vizsgálta [1], bevezetve az

$$
\varepsilon:=\sqrt{\frac{D}{l}}, \quad \mu:=\sqrt{\frac{g}{A}},
$$

paramétereket, ahol a $D$ a fölfüggesztési pont legnagyobb kitérése (amplitúdója) a rezgetés során. A 4.2 tétel formulájában szereplő $\omega_{h} T_{h}, \omega_{e} T_{e}$ paraméterek az $\varepsilon$ és $\mu$ segítségével a következóképpen írhatóak át.

$$
\begin{aligned}
& \omega_{h} T=\sqrt{\frac{A+g}{l}} T=\sqrt{\frac{A(1+g / A)}{l}} T=2 \sqrt{2 \varepsilon} \sqrt{1+\mu^{2}}, \\
& \omega_{e} T=2 \sqrt{2} \varepsilon \sqrt{1-\mu^{2}}, \text { valamint } \\
& \frac{\omega_{h}}{\omega_{e}}=\sqrt{\frac{1+\mu^{2}}{1-\mu^{2}}} .
\end{aligned}
$$

Arnold azzal a föltevéssel élt, hogy ezek a paraméterek kicsik $(\varepsilon<<1, \mu<<1)$; és a monodrómia nyomának sorfejtése során ezt kihasználva jutott arra, hogy $\mu<\varepsilon / 3$ elegendő feltétele az erôs stabilitásnak. Alkalmazzuk a 4.2 tételünket ebben a szimmetrikus, a gravitáció hatását is figyelembe vevő esetben, az $\varepsilon$ és $\mu$ 


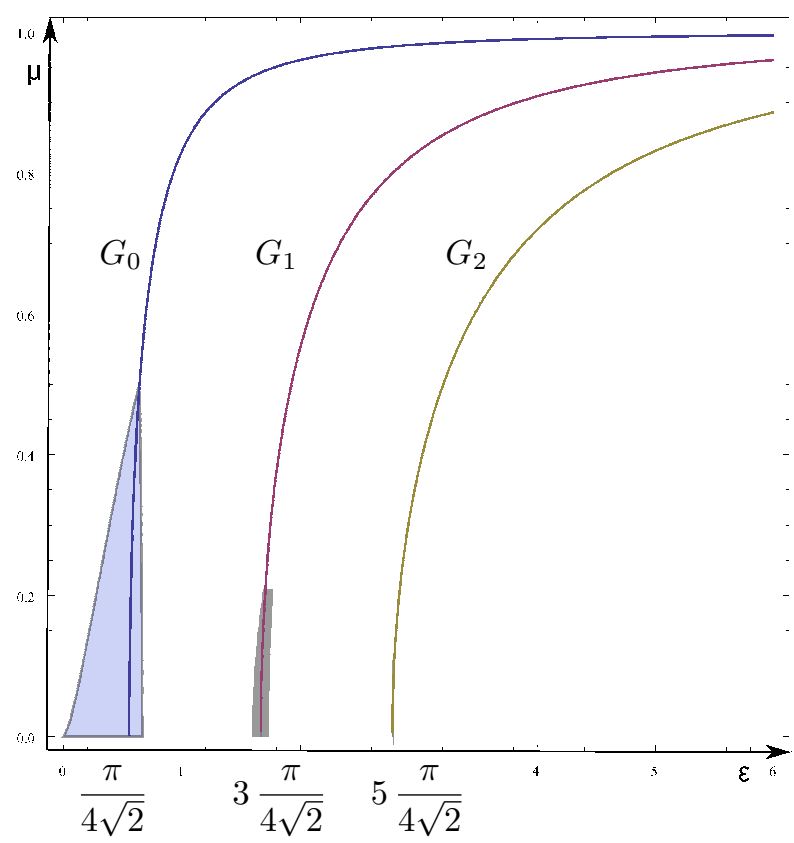

4.7. ábra. Az (4.30) egyenlótlenség $S$ megoldáshalmaza

paraméterek segítségével átírva a (4.26) föltételt. Vegyük észre, hogy ebben az esetben nem tettünk föl semmilyen nagyságrendi korlátot a paraméterek értékeire. Ez azt jelenti, hogy az $\varepsilon-\mu$ sík globális stabilitási térképét fogjuk megkapni.

4.4. Következmény. Tegyük föl, hogy $A_{h}=A_{e}=A, T_{h}=T_{e}=T / 2 . H a$

$$
\begin{aligned}
& 2 \arctan \frac{e^{2 \sqrt{2} \varepsilon \sqrt{1+\mu^{2}}}-1}{e^{2 \sqrt{2} \varepsilon \sqrt{1+\mu^{2}}}+1}+4\left|\arctan \sqrt[4]{\frac{1+\mu^{2}}{1-\mu^{2}}}-\frac{\pi}{4}\right|< \\
& <\min \left\{\operatorname{Rem}\left(2 \sqrt{2} \varepsilon \sqrt{1-\mu^{2}} ; \pi\right) ; \pi-\operatorname{Rem}\left(2 \sqrt{2} \varepsilon \sqrt{1-\mu^{2}} ; \pi\right)\right\},
\end{aligned}
$$

akkor a (4.13) erôsen stabil.

$\mathrm{Az} \varepsilon-\mu$ síkon a stabilitási tartománynak végtelen sok komponense van, melyeket a $2 \sqrt{2} \varepsilon \sqrt{1-\mu^{2}}=k \pi \quad(k=0,1,2, \ldots)$ egyenletú görbék választanak el egymástól. Mivel a (4.30) bal oldalának első tagja tart a $\pi / 2$-be, amint $\varepsilon \rightarrow \infty$, és a második tagja tart $\pi$-be, midôn $\mu \rightarrow 1-0$, ezért a stabilitási tartománynak a $\mu=1$ egyenes közelében nincsen pontja, továbbá a komponensek egyre kevésbé kifejezettek, elvékonyodnak, amikor $k \rightarrow \infty$ (lásd a 4.7 ábrát).

$\mathrm{Az}$ (4.30) jobb oldala a

$$
G_{k}: \quad 2 \sqrt{2} \varepsilon \sqrt{1-\mu^{2}}=(2 k+1) \frac{\pi}{2} \quad(k=0,1, \ldots),
$$


görbék mentén éri el a maximális, $\pi / 2$ értéket, vagyis a (4.30) egyenlótlenség $S \subset \mathbb{R}_{+}^{2}$ megoldáshalmazának $k$-adik komponense a $G_{k}$ görbe környezetében található, másképpen kifejezve, a $k$-adik komponens gerincét a $G_{k}$ görbe alkotja. Jelölje ugyanis $S_{\mu=0}$ az $S$ és az $\varepsilon$-tengely metszetét. Ekkor a $S_{\mu=0}$ pontjai eleget tesznek a

$$
\begin{aligned}
2 & \arctan \frac{e^{2 \sqrt{2} \varepsilon}-1}{e^{2 \sqrt{2} \varepsilon}+1} \\
& <\min \{\operatorname{Rem}(2 \sqrt{2} \varepsilon ; \pi) ; \pi-\operatorname{Rem}(2 \sqrt{2} \varepsilon ; \pi)\},
\end{aligned}
$$

egyenlőtlenségnek, mely biztosan teljesül, ha $\varepsilon=(2 k+1) \pi / 4 \sqrt{2}(k=0,1, \ldots)$. Mivel $S$ nyílt, ezért bármely $k \in \mathbb{N}$ esetén van $G_{k}$ körüli komponense az $\varepsilon$-tengely közelében. Másrészról, mivel az $x \mapsto(x-1) /(x+1)(x \geq 0)$ függvény növekvô, ezért akármilyen $k \in \mathbb{N}$ esetén az $S_{\mu=0}$ halmazba kell esnie a $G_{k}$ végpontjának. Továbbá látható, hogy az $S$ tartalmaz pontot az $\varepsilon$-tengelyrôl, azaz pontot az $S_{\mu=0}$ halmazból. Ezzel bizonyítást nyert, hogy $S$ a $G_{k}$ görbék mentén található komponensekból áll.

Minél nagyobb az $\varepsilon$, annál nehezebb garantálni a (4.13) stabilitását. Mivel $D=\varepsilon^{2} l$, azért azt mondhatjuk, hogy a fölfüggesztési pont rezgetésének egyre nagyobb amplitúdója egyre nehezebbé teszi a fordított inga stabilizálását. Mindazonáltal elméletileg lehetséges megvalósítani. Az úgynevezett kritikus amplitúdók

$$
D^{(k)}=\frac{(2 k+1)^{2} \pi^{2}}{32} l \quad(k=0,1, \ldots),
$$

a végtelenbe divergálnak, amint $k \rightarrow \infty$, s így a nekik megfelelő $A^{(k)}$ gyorsulásokkal az inga fölsó egyensúlyi helyzete stabilizálható. Természetesen $A^{(k)} \rightarrow \infty$, ha $k \rightarrow \infty$.

Tekintsük most az általános (aszimmetrikus) esetet, használva az Arnold nyomán bevezetett

$$
\varepsilon_{h}:=\sqrt{\frac{D_{h}}{l}}, \quad \mu_{h}:=\sqrt{\frac{g}{A_{h}}} ; \quad \varepsilon_{e}:=\sqrt{\frac{D_{e}}{l}}, \quad \mu_{e}:=\sqrt{\frac{g}{A_{e}}} .
$$

paramétereket. Ezek egymástól nem függetlenek, ahogy a (4.12) összefüggések mutatják is. Legyen

$$
d:=\frac{\varepsilon_{h}}{\varepsilon_{e}}=\frac{\mu_{h}}{\mu_{e}}=\sqrt{\frac{A_{e}}{A_{h}}}=\sqrt{\frac{T_{h}}{T_{e}}}=\sqrt{\frac{D_{h}}{D_{e}}},
$$




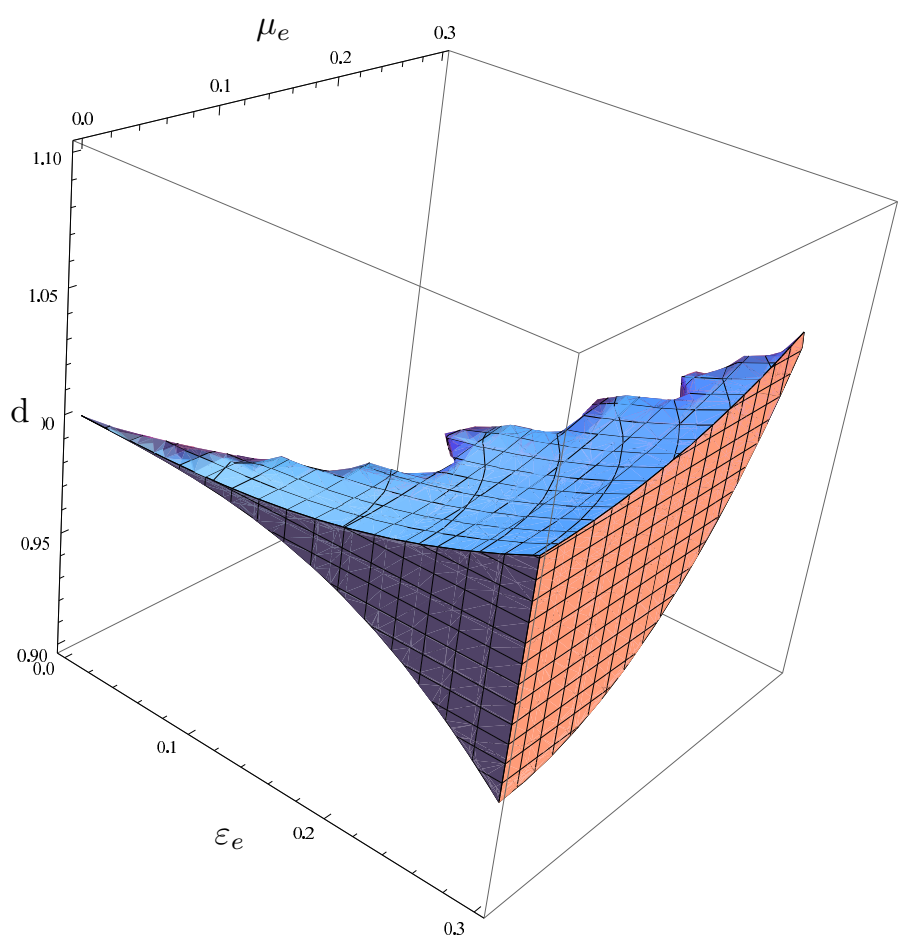

4.8. ábra. A stabilitási tartomány egy része az aszimmetrikus esetben

az a paraméter, amelyik méri a hiperbolikus és elliptikus fázis arányát a fölfüggesztési pont rezgetése során. Az $\varepsilon_{h}, \mu_{h}$ mennyiségeket kifejezve, $\varepsilon_{e}, \mu_{e}, d$ független paraméterek segítségével (a szimmetrikus esetet a $d=1$ fejezi ki) a 4.2 tétel a következő alakot ölti:

\subsection{Következmény. $H a$}

$$
\begin{aligned}
& 2 \arctan \frac{\exp \left[2 \sqrt{2} d \varepsilon_{e} \sqrt{1+d^{2} \mu_{e}^{2}}\right]-1}{\exp \left[2 \sqrt{2} d \varepsilon_{e} \sqrt{1+d^{2} \mu_{e}^{2}}\right]+1}+4\left|\arctan \frac{\sqrt{\frac{1+d^{2} \mu_{e}^{2}}{1-\mu_{e}^{2}}}}{d}-\frac{\pi}{4}\right|< \\
& <\min \left\{\operatorname{Rem}\left(2 \sqrt{2} \varepsilon_{e} \sqrt{1-\mu_{e}^{2}} ; \pi\right) ; \pi-\operatorname{Rem}\left(2 \sqrt{2} \varepsilon_{e} \sqrt{1-\mu_{e}^{2}} ; \pi\right)\right\},
\end{aligned}
$$

akkor a (4.13) egyenlet erösen stabil.

A 4.5 következmény által megadott stabilitási tartomány egy részét láthatjuk a 4.8 ábrán. Ennek a testnek a $d=1$ síkkal vett metszete megfelel a 4.7 ábrán látható stabilitási tartomány elsô komponensének.

A (4.33) feltétel lényegesen nagyobb esélyt ad a stabilizálásra, mint a (4.30). 


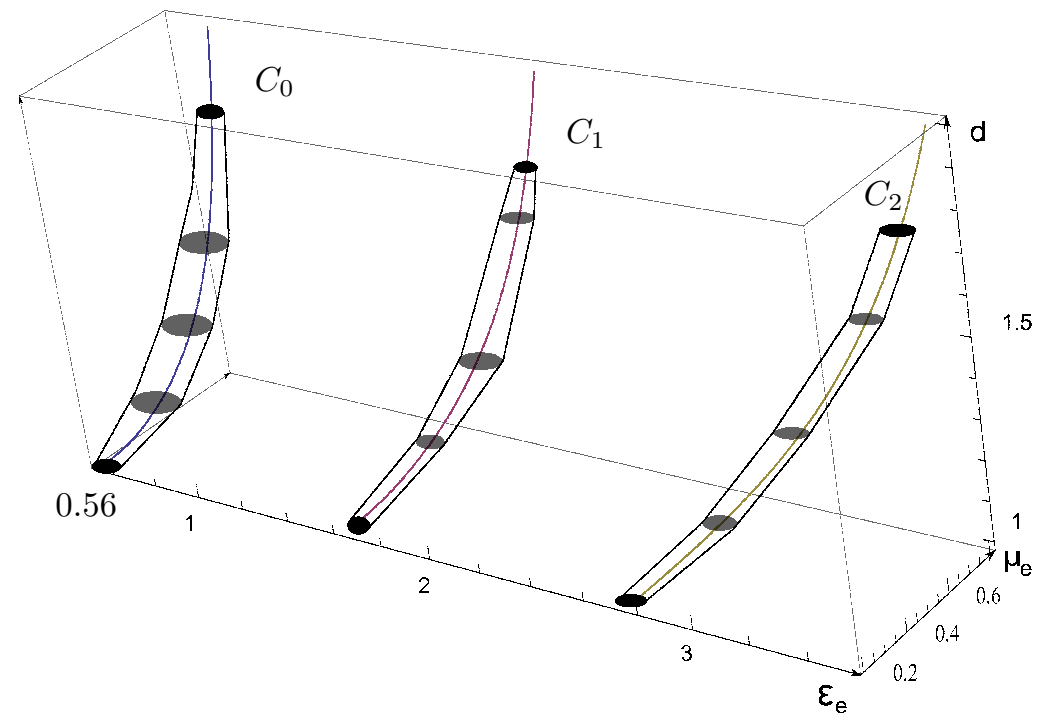

4.9. ábra. Stabilitási tartomány az $\varepsilon_{e}-\mu_{e}-d$-térben

Stabilitás szempontjából egy jó eset, amikor (4.33) bal oldalának második tagja zérus, míg a jobb oldala eléri a maximális, $\pi / 2$ értéket, azaz, ha

$$
\begin{aligned}
1+d^{2} \mu_{e}^{2} & =d^{2}\left(1-\mu_{e}^{2}\right), \\
2 \sqrt{2} \varepsilon_{e} \sqrt{1-\mu_{e}^{2}} & =(2 k+1) \frac{\pi}{2} \quad(k=0,1,2, \ldots) .
\end{aligned}
$$

Ezek a kifejezések az $\varepsilon_{e}-\mu_{e}-d$-tér görbéit definiálják:

$$
\begin{gathered}
C_{k}: d \mapsto\left(\frac{(2 k+1) \pi}{4} \frac{d}{\sqrt{d^{2}+1}}, \frac{\sqrt{d^{2}-1}}{\sqrt{2} d}, d\right) \quad(d \geq 1) \\
(k=0,1,2, \ldots) .
\end{gathered}
$$

A (4.13) egyenlet ezen görbék mentén erôsen stabil, hiszen a (4.33) kifejezés bal oldalának elsô tagja mindig kisebb, mint $\pi / 2$. Más szavakkal kifejezve, az $\varepsilon_{e}-\mu_{e}-d$-térbeli stabilitási tartomány komponensei ezen $C_{k}$ görbék mentén találhatóak, lásd a 4.9 ábrát.

A szimmetrikus eset tárgyalásánál említettük, hogy a fordított inga stabilizálható a fölfüggesztési pont tetszôlegesen nagy amplitúdójú rezgetésével, lásd a (4.32)-ben megadott kritikus értékeket. Ezzel együtt a megfelelő $A^{(k)}$ gyorsulás értékek a végtelenbe divergálnak, amikor $k \rightarrow \infty$, amit meglehetôsen nehéz realizálni. Most, az aszimmetrikus esetben még nagyobb az esély a stabilizálásra, hiszen a gyorsulást egy elôre adott értéken lehet rögzíteni. Tehát bármely $\bar{\mu}_{e}$ 
$\left(0 \leq \bar{\mu}_{e}<\sqrt{2} / 2\right)$ esetén található olyan $\bar{d} \geq 1$ és $\bar{\varepsilon}_{e}^{(k)} \quad\left(\bar{\varepsilon}_{e}^{(k)} \rightarrow \infty\right.$, ha $\left.k \rightarrow \infty\right)$ úgy, hogy a (4.13) egyenlet az $\bar{\varepsilon}_{e}^{(k)}, \bar{\mu}_{e}, \bar{d}$ paraméterekkel erósen stabil. A megfelelő paraméterértékek a (4.34) egyenletekból megkaphatóak:

$$
\bar{d}=\frac{1}{\sqrt{1-2 \bar{\mu}_{e}^{2}}}, \quad \bar{\varepsilon}_{e}^{(k)}=\frac{(2 k+1) \pi}{4 \sqrt{2} \sqrt{1-\bar{\mu}_{e}^{2}}} \quad(k=0,1, \ldots) .
$$

Sikerült tehát a [28] cikkben megismert geometriai módszert kiterjeszteni olyan esetre, amiben az eredeti nem múködik, és így az inga fölsó egyensúlyi helyzetének stabilis állapotait leíró globális stabilitási térképet tudtunk adni. Tárgyalásunk általános jellegének köszönhetően azt is megkaptuk, hogy ha nem szimmetrikus rezgetésnek vetjük alá az inga fölfüggesztési pontját, akkor nagyobb az esélye annak, hogy a fölsó egyensúlyi helyzet stabilissá válik. 


\section{5. fejezet}

\section{A fordított inga periodikus}

\section{mozgásai}

Az elôző fejezetben az inga fölsô egyensúlyi helyzetének stabilizálhatóságával kapcsolatos vizsgálataink során eljutottunk a globális stabilitási térkép elkészítéséig. Fontos megjegyezni, hogy mindezt becsléseken alapuló számolások segítségével kaptuk, így a kapott stabilitási térkép is egy közelítés. A hintázás modelljének tanulmányozásakor szintén elemi geometriai megfontolásokat végezve teljesen pontos stabilitási térképet tudtunk készíteni méghozzá úgy, hogy kihasználtuk a Floquet-elv egy fontos elemét: a $2 T$-periodikus együtthatós egyenlet $2 T$-, illetve $4 T$-periodikus megoldásait föltárva eljutottunk a stabil, instabil zónák határoló görbéihez. Ebben a fejezetben célunk, hogy a fordított ingára vonatkozóan elkészítsük a pontos stabilitási térképet úgy, hogy megkeressük a periodikus megoldásokat. Meggondolásaink követik a [11] dolgozatot.

\subsection{A vizsgált modell}

Ebben a részben azt az esetet tárgyaljuk, amikor az inga fölfüggesztési pontjára egy függőleges irányú szimmetrikus erő gyakorol hatást, továbbá a gravitáció hatását is figyelembe vesszük. Erról a modellrôl olvashatunk Arnold [1] múvében is, ahol a szerzố a monodrómia mátrix nyomának sorfejtésével ad becslést a stabil, instabil zónákra. Ennél pontosabbat fogunk mondani, amit az 5.10 
ábra meglehetősen érzékletesen mutat be. Tekintsük tehát a (4.1) egyenlettel adott lépcsôsfüggvényt mint az inga fölfüggesztési pontjára kifejetett rezgetés hatására létrejövô gyorsulást. A (4.1)-ben adotthoz képest annyi technikai változtatást teszünk, hogy az említett gyorsulás $2 T$-periodikus, azaz

$$
a(t):= \begin{cases}A, & \text { ha } 2 k T \leq t<(2 k+1) T, \\ -A, & \text { ha }(2 k+1) T \leq t<(2 k+2) T, \quad(k=0,1, \ldots),\end{cases}
$$

ahol $A, T$ pozitív konstansok. A mozgásegyenlet a (4.13)-ban már látott

$$
\ddot{\psi}-\frac{1}{l}(g+a(t)) \psi=0
$$

Ezt az egyenletet az $a(t)$ két különböző értékének megfelelően a (4.16)-hez hasonló sajátfrekvenciák bevezetésével tudjuk kezelni. Legyen most

$$
\omega_{h}:=\sqrt{\frac{A+g}{l}}, \quad \omega_{e}:=\sqrt{\frac{A-g}{l}},
$$

tehát $A>g$. Innen a (4.17)-(4.22) kifejezéseket megismételhetjük az értelmezési tartományok értelemszerú módosításával. Ez azt jelenti, hogy a már jól ismert dinamikával találjuk szemben magunkat: hiperbola menti mozgás, dilatáció $\omega_{h} / \omega_{e}>1$ mértékkel az $y$-tengellyel párhuzamosan, origó körüli körön történô mozgás, majd egy $\omega_{e} / \omega_{h}<1$ mértékű kontrakció egymás utáni ismétlése jellemzi a fázispont mozgását. Bennünket azok a mozgások érdekelnek, melyek során a fázispont visszatér a kiinduló állapotba méghozzá vagy egy periódus (2T) vagy két periódus (4T) alatt, hiszen az ilyen mozgásoknak megfelelő pontok alkotják a stabil, instabil zónák határait képező görbéket. Mindenek elôtt a szükséges technikai eszközöket tekintsük át.

Ahogy már láttuk, a (4.20)-beli második egyenlet szeparábilis, így írhatjuk, hogy

$$
\int_{0}^{t} \frac{\dot{\varphi_{h}}(s) \mathrm{d} s}{\cos 2 \varphi_{h}(s)}=\omega_{h} t, \quad 0 \leq t \leq T
$$

vagyis

$$
\int_{\varphi_{0}}^{\varphi_{h}(t)} \frac{\mathrm{d} \varphi}{\cos 2 \varphi}=\omega_{h} t, \quad \varphi_{0}:=\varphi_{h}(0) \neq-\frac{\pi}{4} .
$$

Legyen $G(\varphi):=\int \mathrm{d} \varphi / \cos 2 \varphi$. Ekkor

$$
G(\varphi)=-\frac{1}{2} \ln \left|\tan \left(\frac{\pi}{4}-\varphi\right)\right|,
$$




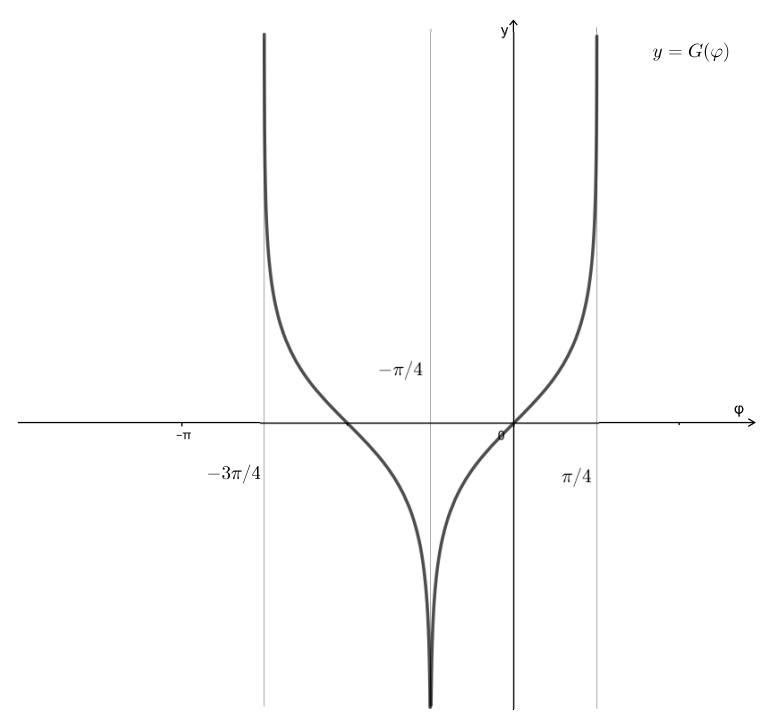

5.1. ábra. A G függvény grafikonja

azaz

$$
G(\varphi):= \begin{cases}-\frac{1}{2} \ln \tan \left(\frac{\pi}{4}-\varphi\right), & \text { ha }-\pi / 4<\varphi<\pi / 4, \\ -\frac{1}{2} \ln \tan \left(\varphi-\frac{\pi}{4}\right), & \text { ha }-3 \pi / 4<\varphi<-\pi / 4 .\end{cases}
$$

Az (5.3) alapján azt kapjuk, hogy

$$
\varphi_{h}(t)=G^{-1}\left(\omega_{h} t+G\left(\varphi_{0}\right)\right)
$$

Speciálisan,

$$
\varphi_{h}(T-0)=G^{-1}\left(\omega_{h} T+G\left(\varphi_{0}\right)\right),
$$

ahol $\varphi_{h}(T-0)$ a $\varphi T$-beli bal oldali limeszét jelöli. Most már meg tudjuk adni a (4.20) második egyenletének megoldását:

$\varphi_{h}\left(t ; \varphi_{0}\right):= \begin{cases}\frac{\pi}{4}-\arctan \left(e^{-2 \omega_{h} t} \tan \left(\frac{\pi}{4}-\varphi_{0}\right)\right), & \text { ha }-\pi / 4<\varphi_{0}<\pi / 4, \\ \frac{\pi}{4}+\arctan \left(e^{-2 \omega_{h} t} \tan \left(\varphi_{0}-\frac{\pi}{4}\right)\right), & \text { ha }-3 \pi / 4<\varphi_{0}<-\pi / 4 .\end{cases}$

Meggondolásainkat a $(-3 \pi / 4, \pi / 4)$ intervallumra mondtuk ki, aminek az oka, hogy a mozgásegyenlet lineáris, így ha $t \mapsto(x(t), y(t))$ egy megoldás, akkor a $t \mapsto(-x(t),-y(t))$ szintén egy megoldás, vagyis elég az egyik $\pi$ hosszú intervallummal foglalkoznunk. 


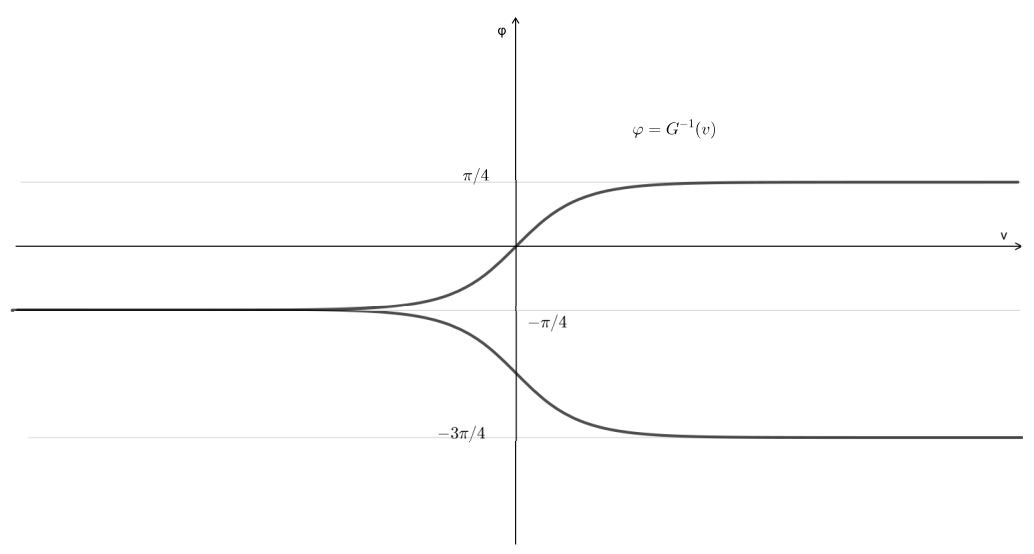

5.2. ábra. A $G^{-1}$ függvény grafikonja

Ahogy azt tudjuk, az (5.2) mozgásegyenletben az együtthatófüggvény szakaszonként folytonos. Ennek megfelelően egy $\psi: \mathbb{R} \rightarrow \mathbb{R}$ függvény az (5.2) egy megoldása, ha folytonosan differenciálható az $\mathbb{R}$ halmazon, kétszer differenciálható az

$$
S:=\mathbb{R} \backslash\{k T\}_{k \in \mathbb{N}}
$$

halmazon, és kielégíti a mozgásegyenletet az $S$-en. Bármely $\psi$ megoldás az $x_{h}$ : $[2 k T,(2 k+1) T) \rightarrow \mathbb{R}$ és az $x_{e}:[(2 k+1) T,(2 k+2) T) \rightarrow \mathbb{R}$ megoldásokból áll, rendre a (4.19) és (4.21) egyenleteknek megfelelően, $(k \in \mathbb{N})$. A $\dot{\psi}$ folytonosságát garantálandó az $\mathbb{R}$-en, megköveteljük az alábbi feltételeket:

$$
\begin{aligned}
& x_{e}((2 k+1) T)=\lim _{t \rightarrow(2 k+1) T-0} x_{h}(t), \\
& x_{h}((2 k+2) T)=\lim _{t \rightarrow(2 k+2) T-0} x_{e}(t) ; \\
& \omega_{e} y_{e}((2 k+1) T)=\lim _{t \rightarrow(2 k+1) T-0} \omega_{h} y_{h}(t), \\
& \omega_{h} y_{h}((2 k+2) T)=\lim _{t \rightarrow(2 k+2) T-0} \omega_{e} y_{e}(t) .
\end{aligned}
$$

Az (5.5) geometriai jelentése az elliptikus és hiperbolikus fázisok között föllépó „ugrás". Ahogyan a hintázás problémájának földolgozásakor, úgy most is használni fogjuk az ott bevezetett $f$ és $\phi$ függvényeket. Emlékeztetőül: ha rendre $\left(r_{R}, \varphi_{R}\right)$, illetve $\left(r_{C}, \varphi_{C}\right)=(\rho(r, \varphi ; \kappa), \phi(\varphi ; \kappa))$ jelöli az $(r, \varphi)$ pont képét az origó körüli, $\alpha$ szögú forgatás, illetve a $\kappa$ mértékú kontrakció-dilatáció során, akkor 
egyrészt $r_{R}(r, \varphi)=r, \varphi_{R}(r, \varphi)=\varphi-\alpha$, másrészt

$$
\begin{gathered}
\rho(r, \varphi ; \kappa)=\sqrt{x^{2}+\kappa^{2} y^{2}}=r \sqrt{1+\left(\kappa^{2}-1\right) \sin ^{2} \varphi}=f(\varphi ; \kappa) r, \\
f(\varphi, \kappa):=\sqrt{1+\left(\kappa^{2}-1\right) \sin ^{2} \varphi}, \quad(\kappa>0,-\infty<\varphi<\infty) .
\end{gathered}
$$

Továbbá, mivel $\tan \phi(\varphi ; \kappa)=\kappa y / x=\kappa \tan \varphi(x \neq 0$, vagyis $\varphi \not \equiv \pi / 2(\bmod \pi))$, így tehát

$\phi(\varphi ; \kappa):=\left\{\begin{array}{ll}\arctan (\kappa \tan \varphi)+\left[\frac{\varphi+\frac{\pi}{2}}{\pi}\right] \cdot \pi, & \text { ha } \varphi \neq(2 k+1) \frac{\pi}{2}, \\ \varphi, & \text { ha } \varphi=(2 k+1) \frac{\pi}{2},\end{array} \quad(k \in \mathbb{Z})\right.$,

ahol $[x]$ jelöli az $x \in \mathbb{R}$ szám egészrészét. Szintén emlékeztetőül említjük, hogy a számolásaink során gyakran használjuk az $f$ és $\phi$ függvények tulajdonságait (részletesen lásd 3.7 lemmát). Az ott fölsorolt tulajdonságok közül megemlítjük, hogy $f$ páros függvény, a $\phi$ pedig páratlan, továbbá $\phi(\cdot+k \pi ; \kappa)=\phi(\cdot ; \kappa)+k \pi$ $(k \in \mathbb{Z}) ; \phi(\phi(\varphi ; \kappa) ; 1 / \kappa)=\varphi(\varphi \in \mathbb{R})$.

\subsection{Periodikus pályák konstruálása}

Induljon a $t \mapsto(r(t), \varphi(t))$ trajektória az $r_{0}, \varphi_{0}$ pontból a $t_{0}=0$ időpillanatban. A trajektória elsó öt nevezetes pontját a következóképpen adhatjuk meg, bevezetve a $D:=\omega_{h} / \omega_{e}>1$ jelölést:

$$
\begin{array}{ll}
r_{0}:=r(0), & \varphi_{0}: \equiv \varphi(0) \quad(\bmod 2 \pi),-2 \pi<\varphi_{0} \leq 0 ; \\
r_{1}:=r(T-0), & \varphi_{1}:=\varphi(T-0) ; \\
r_{2}:=r(T)=f\left(\varphi_{1} ; D\right) r_{1}, & \varphi_{2}:=\varphi(T)=\phi\left(\varphi_{1} ; D\right) ; \\
r_{3}:=r(2 T-0)\left(=r_{2}\right), & \varphi_{3}:=\varphi(2 T-0) ; \\
r_{4}:=r(2 T)=f\left(\varphi_{3} ; 1 / D\right) r_{3}, & \varphi_{4}:=\varphi(2 T)=\phi\left(\varphi_{3} ; 1 / D\right) .
\end{array}
$$

A rendszer viselkedését a $[2 k T,(2 k+1) T)$ intervallumon leíró $\ddot{\psi}-\omega_{h}^{2} \psi=0$, és a $[(2 k+1) T,(2 k+2) T) \quad(k \in \mathbb{N})$ intervallumon megadó $\ddot{\psi}+\omega_{e}^{2} \psi=0$ egyenletek linearitása miatt minden megoldás ellentettje is megoldás, ahogyan erre már korábban utaltunk. Ebból kifolyólag elegendő a $-\pi / 2 \leqq \varphi_{0}<\pi / 2$ esetet vizsgálnunk. 
5.1. Lemma. Legyen $\varphi_{0} \in[-\pi / 2, \pi / 2)$. Ekkor a $t \mapsto(r(t), \varphi(t))$ egy, az $(5.2)$ egyenlet $2 T$-periodikus megoldásának megfelelô trajektória akkor és csakis akkor, ha vagy

(a) $-\pi / 4<\varphi_{0}<0$ és van olyan $k$ nemnegativ egész szám úgy, hogy

$$
\left\{\begin{array}{l}
\varphi_{1}=-\varphi_{0} \\
\varphi_{3}=-\varphi_{2}-2 k \pi
\end{array}\right.
$$

vagy

(b) $-\pi / 2<\varphi_{0}<-\pi / 4$ és van olyan $k$ nemnegatív egész szám úgy, hogy

$$
\left\{\begin{array}{l}
\varphi_{1}=-\varphi_{0}-\pi \\
\varphi_{3}=-\varphi_{2}-\pi-2(k+1) \pi
\end{array}\right.
$$

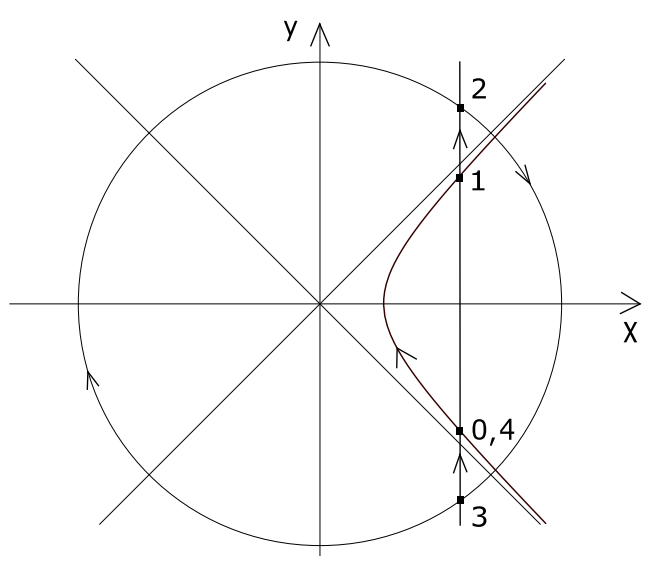

5.3. ábra. Egy $2 T$-periodikus pálya, (a).

Bizonyítás. Szükségesség. Legyen $\psi$ az (5.2) egyenlet egy $2 T$-periodikus megoldása úgy, hogy $-\pi / 2<\varphi_{0}<\pi / 2$. A (4.20) egyenletekból adódik, hogy minden hiperbola kielégít egy

$$
\frac{\mathrm{d} r}{\mathrm{~d} \varphi}=r \tan 2 \varphi \quad\left(-\frac{\pi}{4}+m \frac{\pi}{2}<\varphi<\frac{\pi}{4}+m \frac{\pi}{2}, m \in\{-1,0,1\}\right)
$$

differenciálegyenletet. Az (5.9) szeparábilis, integrálva azt kapjuk, hogy

$$
\frac{r}{r_{0}}=\sqrt{\frac{\left|\cos 2 \varphi_{0}\right|}{|\cos 2 \varphi|}} \quad\left(-\frac{\pi}{4}+m \frac{\pi}{2}<\varphi_{0}, \varphi<\frac{\pi}{4}+m \frac{\pi}{2}, m \in\{-1,0,1\}\right) .
$$




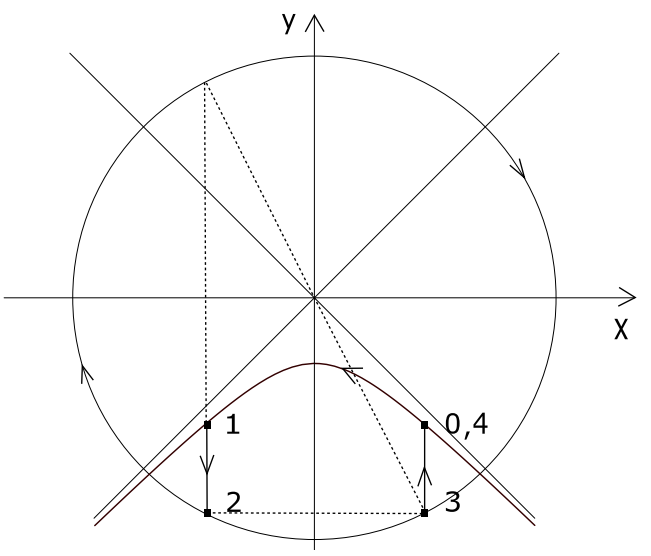

5.4. ábra. Egy 2T-periodikus pálya, (b).

Használva az (5.6) jelöléseit és az $f$ függvény tulajdonságait, azt írhatjuk, hogy

$$
r_{3}=f\left(\varphi_{0} ; D\right) r_{0}, \quad r_{2}=f\left(\varphi_{1} ; D\right) r_{1}
$$

Mivel a megoldás $2 T$-periodikus, és $r_{3}=r_{2}$, ezért

$$
\frac{r_{1}}{r_{0}}=\frac{f\left(\varphi_{0} ; D\right)}{f\left(\varphi_{1} ; D\right)}=\sqrt{\frac{1+\left(D^{2}-1\right) \sin ^{2} \varphi_{0}}{1+\left(D^{2}-1\right) \sin ^{2} \varphi_{1}}} .
$$

Másrészt

$$
\frac{r_{1}}{r_{0}}=\sqrt{\frac{\left|\cos 2 \varphi_{0}\right|}{\left|\cos 2 \varphi_{1}\right|}} .
$$

Az előzőek összevetéséből adódik, hogy

$$
\sqrt{\frac{\left|\cos 2 \varphi_{0}\right|}{\left|\cos 2 \varphi_{1}\right|}}=\sqrt{\frac{1+\left(D^{2}-1\right) \sin ^{2} \varphi_{0}}{1+\left(D^{2}-1\right) \sin ^{2} \varphi_{1}}}
$$

melynek segítségével definiáljuk az alábbi $h$ függvényt, lásd a 5.5 ábrát:

$$
h(\varphi):=\frac{|\cos 2 \varphi|}{1+\left(D^{2}-1\right) \sin ^{2} \varphi} .
$$

A $h$ függvény használatával (5.10) összefüggést úgy fejezhetjük ki, hogy $h\left(\varphi_{0}\right)=$ $h\left(\varphi_{1}\right)$.

Megmutatható, hogy $h$ szigorúan monoton növekvő a $[\pi / 4+m \pi / 2, \pi / 2+$ $m \pi / 2]$, míg szigorúan monoton csökkenô az $[m \pi / 2, \pi / 4+m \pi / 2](m \in \mathbb{Z})$ intervallumon.

Ha $\varphi_{0} \in[0, \pi / 4]$ vagy $\varphi_{0} \in[\pi / 4, \pi / 2]$, akkor $\varphi_{1}$ ugyanabba az intervallumba esik, mint $\varphi_{0}$. Mivel $h$ szigorúan monoton ezeken az intervallumokon, ezért 


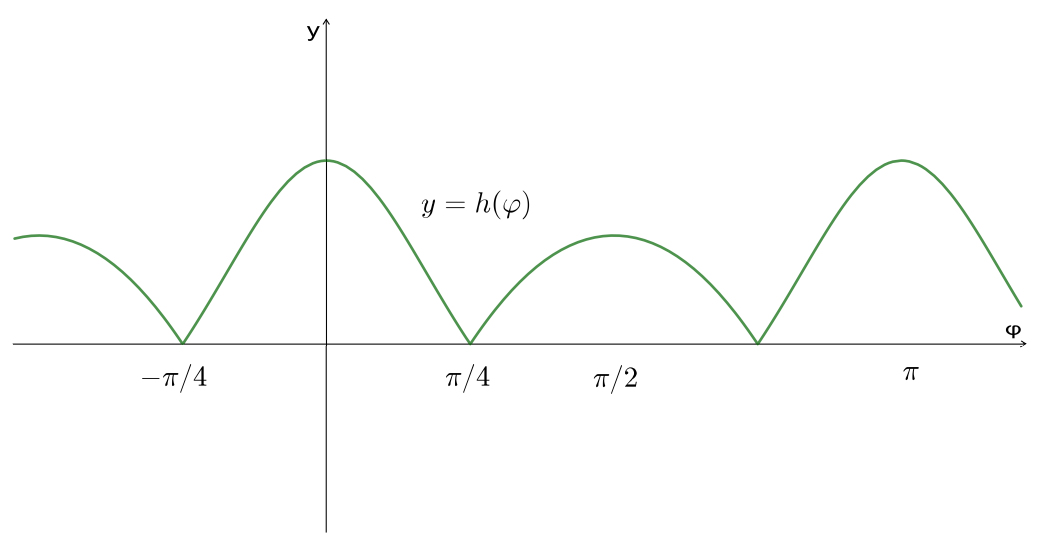

5.5. ábra. A h függvény grafikonja

$h\left(\varphi_{0}\right)=h\left(\varphi_{1}\right)$ nem teljesülhet. Ez azt jelenti, hogy $2 T$-periodikus megoldás nem indulhat ilyen $\varphi_{0}$ állapotból.

A $h$ függvény páros és periodikus, periódusa $\pi$, vagyis, ha $\varphi_{0} \in(-\pi / 4,0)$, akkor pontosan egy olyan $\varphi_{1} \in(0, \pi / 4)$ létezik, melyre $h\left(\varphi_{0}\right)=h\left(\varphi_{1}\right)$, tehát teljesül (5.7) első egyenlete. Ha $\varphi_{0} \in(-\pi / 2,-\pi / 4)$, akkor pontosan egy olyan $\varphi_{1} \in(-3 \pi / 4,-\pi / 2)$ létezik, hogy $h\left(\varphi_{0}\right)=h\left(\varphi_{1}\right)$, így tehát (5.8) elsố egyenlete teljesül.

Az (a) esetben a $\varphi_{1}=-\varphi_{0}$ miatt az $1 \rightarrow 2$ dilatáció és a $3 \rightarrow 4=3 \rightarrow$ 0 kontrakció ugyanazon függőleges egyenes mentén zajlik (lásd a 5.3 ábrát). Ebból következik, hogy $\frac{\varphi_{2}+\left(\varphi_{3}+2 k \pi\right)}{2}=0$, amiból átrendezéssel kapjuk (5.7) második egyenletét.

Hasonlóképpen, a (b) esetben $\frac{\varphi_{2}+\left(\varphi_{3}+2(k+1) \pi\right)}{2}=-\pi / 2$ (lásd a 5.4 ábrát). Ezt alkalmasan átrendezve kapjuk a (5.8) második egyenletét.

Elegendôség. Az (a) eset. Tegyük föl, hogy a fázispont úgy mozog a fázissíkon, hogy (5.7) teljesül. Fölhasználva az (5.6) jelöléseit, valamint az $f$ és a $\phi$ függvények tulajdonságait azt kapjuk, hogy

$$
\begin{aligned}
\varphi_{4} & =\phi\left(-\varphi_{2}-2 k \pi ; 1 / D\right)=\phi\left(-\varphi_{2} ; 1 / D\right)-2 k \pi=\phi\left(-\phi\left(\varphi_{1} ; D\right) ; 1 / D\right)-2 k \pi \\
& =\phi\left(-\phi\left(-\varphi_{0} ; D\right) ; 1 / D\right)-2 k \pi=\varphi_{0}-2 k \pi .
\end{aligned}
$$

Másfelől

$$
\begin{aligned}
r_{4} & =f\left(\varphi_{3} ; 1 / D\right) r_{3}=f\left(-\varphi_{2}-2 k \pi ; 1 / D\right) r_{2}=f\left(-\phi\left(\varphi_{1} ; D\right) ; 1 / D\right) f\left(\varphi_{1} ; D\right) r_{1} \\
& =f\left(\phi\left(-\varphi_{0} ; D\right) ; 1 / D\right) f\left(-\varphi_{0} ; D\right) r_{0}=f\left(-\phi\left(-\varphi_{0} ; D\right) ; 1 / D\right) f\left(\varphi_{0} ; D\right) r_{0}=r_{0}
\end{aligned}
$$


A (b) eset hasonló számolásokkal mutatható meg.

5.2. Lemma. Legyen $\varphi_{0} \in[-\pi / 2, \pi / 2)$. A $t \mapsto(r(t), \varphi(t))$ akkor és csakis akkor az (5.2) egyenlet egy 4T-periodikus, de nem 2T-periodikus megoldásának megfeleló trajektória, ha vagy

(a) $-\pi / 4<\varphi_{0}<0$ és van olyan $k$ nemnegatív egész szám, hogy

$$
\left\{\begin{array}{l}
\varphi_{1}=-\varphi_{0} \\
\varphi_{3}=-\varphi_{2}-\pi-2 k \pi
\end{array}\right.
$$

vagy

(b) $-\pi / 2<\varphi_{0}<-\pi / 4$ és van olyan $k$ nemnegatív egész szám, hogy

$$
\left\{\begin{array}{l}
\varphi_{1}=-\varphi_{0}-\pi \\
\varphi_{3}=-\varphi_{2}-2 \pi-2 k \pi .
\end{array}\right.
$$

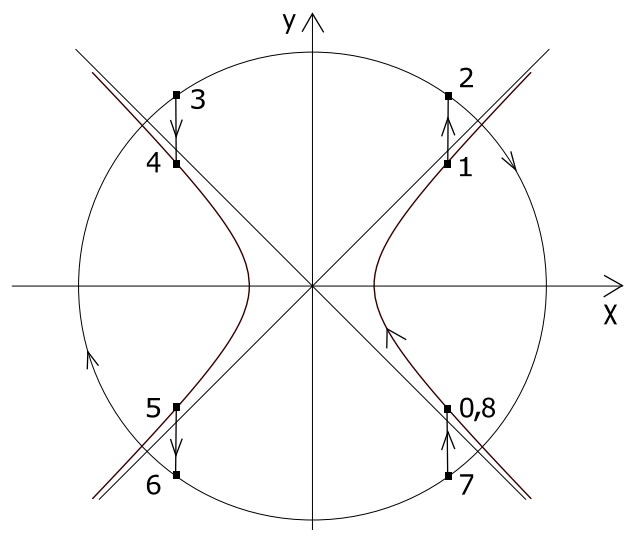

5.6. ábra. Egy $4 T$-periodikus pálya, (a).

\section{Bizonyítás.}

$\mathrm{Az}$ (5.2) alapegyenlet lineáris, ezért egy $t \mapsto(r(t), \varphi(t))$ megoldás 4T-, de nem $2 T$-periodikus pontosan akkor, ha $r(2 T)=r(0), \varphi(2 T) \equiv \varphi(0)-\pi$ $(\bmod 2 \pi)$. Ebból következik, hogy az állítás szükségességét ugyanúgy lehet bizonyítani, mint az 5.1 lemma esetében. 


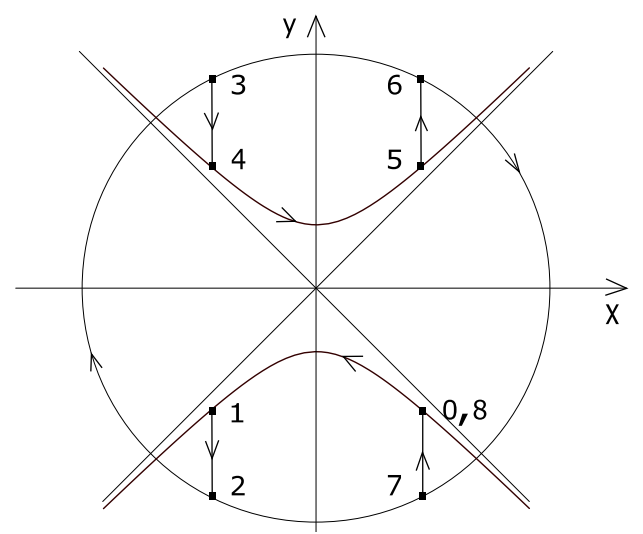

5.7. ábra. Egy $4 T$-periodikus pálya, (b).

Elegendôség. Az (a) eset. Ha (5.11) teljesül, akkor az (5.6) jelöléseit használva írhatjuk, hogy

$$
\begin{aligned}
\varphi_{4}= & \phi\left(-\varphi_{2}-\pi-2 k \pi ; 1 / D\right)=\phi\left(-\varphi_{2} ; 1 / D\right)-(2 k+1) \pi=\phi\left(-\phi\left(\varphi_{1} ; D\right) ; 1 / D\right) \\
& -(2 k+1) \pi=\phi\left(-\phi\left(-\varphi_{0} ; D\right) ; 1 / D\right)-(2 k+1) \pi=\varphi_{0}-(2 k+1) \pi .
\end{aligned}
$$

Tehát $\varphi_{4} \equiv \varphi_{0}-\pi(\bmod 2 \pi)$, amit bizonyítani akartunk. Továbbá

$$
\begin{aligned}
r_{4} & =f\left(\varphi_{3} ; 1 / D\right) r_{3}=f\left(-\varphi_{2}-\pi-2 k \pi ; 1 / D\right) r_{2}=f\left(-\phi\left(\varphi_{1} ; D\right) ; 1 / D\right) f\left(\varphi_{1} ; D\right) r_{1} \\
& =f\left(\phi\left(\varphi_{0} ; D\right) ; 1 / D\right) f\left(-\varphi_{0} ; D\right) r_{0}=f\left(\phi\left(\varphi_{0} ; D\right) ; 1 / D\right) f\left(\varphi_{0} ; D\right) r_{0}=r_{0} .
\end{aligned}
$$

A (b) eset, akár az 5.1 lemma esetén, hasonló számolások segítségével bizonyítható.

A következôben megadunk két tételt, melyek szükséges és elegendő feltételeket jelentenek az (5.2) egyenlet $2 T$-, valamint 4T-periodikus megoldásának létezésére.

5.3. Tétel. Az (5.2) egyenletnek akkor és csakis akkor van $2 T$-periodikus megoldása, ha vannak olyan A és T pozitív konstansok az (5.1) kifejezésben, és van olyan nemnegativ egész $k$, hogy vagy

$$
2 \arctan \left(D \frac{e^{\omega_{h} T}-1}{e^{\omega_{h} T}+1}\right)+2 k \pi=\omega_{e} T,
$$

vagy

$$
2 \arctan \left(D \frac{e^{\omega_{h} T}+1}{e^{\omega_{h} T}-1}\right)+(2 k+1) \pi=\omega_{e} T
$$


5.4. Tétel. Az (5.2) egyenletnek akkor és csakis akkor van 4T-periodikus, de nem 2T-periodikus megoldása, ha vannak olyan A és T pozitív konstansok az (5.1) kifejezésben, és van olyan nemnegativ egész $k$, hogy vagy

$$
2 \arctan \left(D \frac{e^{\omega_{h} T}-1}{e^{\omega_{h} T}+1}\right)+(2 k+1) \pi=\omega_{e} T
$$

vagy

$$
2 \arctan \left(D \frac{e^{\omega_{h} T}+1}{e^{\omega_{h} T}-1}\right)+2 k \pi=\omega_{e} T .
$$

Bizonyítás. [Az 5.3 tétel bizonyítása. Szükségesség.] Tegyük föl, hogy $\psi$ az (5.2) egyenlet egy 2T-periodikus megoldása, továbbá, hogy az 5.1 lemma (a) esete érvényes. Bebizonyítjuk, hogy ebben az esetben (5.13) teljesül. Elliptikus forgásnál $\dot{\varphi}=-\omega_{e}$, ezért

$$
\varphi_{3}-\varphi_{2}=-\omega_{e} T
$$

A $\varphi_{0}$ segítségével kifejezzük az (5.17) formulából $\varphi_{2}$-t és $\varphi_{3}$-t. Ezt megtehetjük, ha fölhasználjuk, hogy

$$
\varphi_{2}=\phi\left(\varphi_{1} ; D\right)=\phi\left(-\varphi_{0} ; D\right), \varphi_{3}=\phi\left(\varphi_{0} ; D\right)-2 k \pi
$$

Ezek közül az elsô nyilvánvaló. A második esetében pedig vegyük figyelembe, hogy $-\pi / 4<\varphi_{0}<0$ és $\varphi_{1}=-\varphi_{0}$ maga után vonja, hogy

$$
0<\varphi_{2}=\phi\left(\varphi_{1} ; D\right)<\frac{\pi}{2}
$$

Ezért (5.7) második egyenlete azt adja, hogy

$$
-2 k \pi-\frac{\pi}{2}<\varphi_{3}=-\varphi_{2}-2 k \pi<-2 k \pi .
$$

Másfelól, a periodicitás miatt $\varphi_{0} \equiv \varphi_{4}=\phi\left(\varphi_{3} ; 1 / D\right)(\bmod 2 \pi)$, így $\varphi_{3}=$ $\phi\left(\varphi_{4} ; D\right) \equiv \phi\left(\varphi_{0} ; D\right)(\bmod 2 \pi)$. Ezek alapján tehát $\varphi_{3}=\phi\left(\varphi_{0} ; D\right)-2 k \pi$.

Most már az (5.17) átírható a következóképpen.

$$
2 \phi\left(\varphi_{0} ; D\right)-2 k \pi=-\omega_{e} T
$$

vagyis

$$
2 \arctan \left(D \tan \varphi_{0}\right)-2 k \pi=-\omega_{e} T
$$

Másrészt, (5.4) szerint $\varphi_{1}=\frac{\pi}{4}-\arctan \left(e^{-2 \omega_{h} T} \tan \left(\frac{\pi}{4}-\varphi_{0}\right)\right)$, ezért

$$
e^{-2 \omega_{h} T}=\frac{\tan \left(\frac{\pi}{4}-\varphi_{1}\right)}{\tan \left(\frac{\pi}{4}-\varphi_{0}\right)}=\frac{\tan \left(\frac{\pi}{4}+\varphi_{0}\right)}{\tan \left(\frac{\pi}{4}-\varphi_{0}\right)}=\left(\frac{1+\tan \varphi_{0}}{1-\tan \varphi_{0}}\right)^{2},
$$


amiból

$$
\tan \varphi_{0}=\frac{1-e^{\omega_{h} T}}{1+e^{\omega_{h} T}}
$$

Az (5.19) (5.18)-ba történő behelyettesítésével megkapjuk az (5.13)-at.

Most tegyük föl, hogy az 5.1 lemma (b) esete teljesül. Az előzóhöz hasonlóan adódik, hogy

$$
2 \arctan \left(D \tan \left(-\varphi_{0}\right)\right)-\pi+(k+1) 2 \pi=\omega_{e} T
$$

és

$$
\tan \varphi_{0}=\frac{1+e^{\omega_{h} T}}{1-e^{\omega_{h} T}}
$$

ami (5.14)-et eredményezi.

Elegendôség. Tegyük föl, hogy (5.13) teljesül. Megmutatjuk, hogy az olyan megoldás, melyre

$$
\varphi_{0}:=\arctan \frac{1-e^{\omega_{h} T}}{1+e^{\omega_{h} T}}
$$

$2 T$-periodikus. Ezt úgy tesszük, hogy belátjuk (5.7) teljesülését. Az (5.22) alapján nyilvánvaló, hogy

$$
e^{\omega_{h} T}=\frac{1-\tan \varphi_{0}}{1+\tan \varphi_{0}} .
$$

$\mathrm{A} \varphi_{1}=\frac{\pi}{4}-\arctan \left(e^{-2 \omega_{h} T} \tan \left(\frac{\pi}{4}-\varphi_{0}\right)\right)$ alapján ez azt jelenti, hogy

$$
\tan \left(\frac{\pi}{4}-\varphi_{1}\right)=\frac{1+\tan \varphi_{0}}{1-\tan \varphi_{0}}
$$

és ezáltal $\varphi_{1}=-\varphi_{0}$. Megmutatjuk, hogy az (5.7) második egyenlete is teljesül. A $\varphi_{3}-\varphi_{2}=-\omega_{e} T$ és (5.13) együttesen adják, hogy

$$
2 \arctan \left(D \frac{e^{\omega_{h} T}-1}{e^{\omega_{h} T}+1}\right)+2 k \pi=-\left(\varphi_{3}-\varphi_{2}\right) .
$$

Ugyanakkor az (5.19) alapján azt írhatjuk, hogy $\varphi_{2}=\phi\left(\varphi_{1} ; D\right)=-\phi\left(\varphi_{0} ; D\right)=$ $-\arctan \left(D \tan \varphi_{0}\right)=-\arctan \left(D \frac{1-e^{\omega_{h} T}}{1+e^{\omega_{h} T}}\right)$, ezért $2 \varphi_{2}+2 k \pi=-\varphi_{3}+\varphi_{2}$, azaz, $\varphi_{3}=-\varphi_{2}-2 k \pi$. Bizonyítottuk tehát, hogy (5.7) teljesül. Az 5.1 lemma garantálja, hogy a megoldás $2 T$-periodikus.

Induljunk most ki (5.14)-ból, és legyen

$$
\varphi_{0}:=-\arctan \frac{e^{\omega_{h} T}+1}{e^{\omega_{h} T}-1} \in\left(-\frac{\pi}{2},-\frac{\pi}{4}\right)
$$

Az elôzố okoskodást lépésról-lépésre megismételve azt kapjuk, hogy az (5.8) teljesül, és a megoldás ezzel a $\varphi_{0}$-lal $2 T$-periodikus. 
Bizonyítás. [Az 5.4 tétel bizonyítása. Szükségesség.] Tegyük föl, hogy van egy olyan 4T-periodikus megoldásunk, amelyik nem $2 T$-periodikus, továbbá, hogy (5.11) teljesül. Megkapjuk az (5.15) formulát, ha kifejezzük $\varphi_{2}$-t és $\varphi_{3}$-t a $\varphi_{0}$ segítségével a $\varphi_{3}-\varphi_{2}=-\omega_{e} T$ egyenletben.

Mivel $-\pi / 4<\varphi_{0}<0$ és $\varphi_{2}=\phi\left(\varphi_{1} ; D\right)=\phi\left(-\varphi_{0} ; D\right)$, ezért azt kapjuk, hogy $0<\varphi_{2}<\pi / 2$. Az (5.11)-tal együtt ez azt jelenti, hogy

$$
\frac{-3 \pi}{2}-2 k \pi<\varphi_{3}=-\varphi_{2}-\pi-2 k \pi<-\pi-2 k \pi
$$

Miután a megoldás $4 T$-periodikus, ezért $\varphi_{3}=\phi\left(\varphi_{4} ; D\right) \equiv \phi\left(\varphi_{0}-\pi ; D\right)(\bmod 2 \pi)$, tehát

$$
\varphi_{3}=\phi\left(\varphi_{0}-\pi ; D\right)-2 k \pi=\phi\left(\varphi_{0} ; D\right)-\pi-2 k \pi
$$

A $\varphi_{3}-\varphi_{2}=-\omega_{e} T$ a következóképp írható most már:

$\omega_{e} T=-\left(\phi\left(\varphi_{0} ; D\right)-\pi-2 k \pi\right)-\phi\left(-\varphi_{0} ; D\right)=2 \arctan \left(D \tan \left(-\varphi_{0}\right)\right)+(2 k+1) \pi$.

$\mathrm{Az}$ (5.19) figyelembevételével megkaptuk az (5.15) kifejezést.

Ha (5.12)-ból indulunk ki, akkor (5.19) helyett az (5.21) fölhasználásával az előzőhöz hasonló számolás után megkapjuk az (5.16) formulát.

Elegendôség. Hasonlóan az 5.3 tétel bizonyításában látottakhoz, megmutatható, hogy ha (5.15) teljesül, és $\varphi_{0}$ az (5.22) által van definiálva, akkor (5.11) igaz, és a megoldás 4T-periodikus az 5.2 lemma alapján. Ugyanígy, ha (5.16) teljesül, és $\varphi_{0}$ az (5.23) alapján definiált, akkor (5.12) igaz, és a megoldás ebben az esetben is $4 T$-periodikus.

Az 5.3 és 5.4 tételek megfelelő alapot jelentenek arra, hogy egy oszcillációs tételt mondjunk ki az (5.2) egyenletre, amely a 3.14 tétel analogonja.

Vezessük be a következóket:

$$
\alpha(T ; A):=2 \arctan \left(D \frac{e^{\omega_{h} T}-1}{e^{\omega_{h} T}+1}\right), \quad \beta(T ; A):=2 \arctan \left(D \frac{e^{\omega_{h} T}+1}{e^{\omega_{h} T}-1}\right) .
$$

$\alpha$ (alulról nézve) konkáv, míg $\beta$ konvex, következésképpen (5.13)-(5.16) minden egyenletének pontosan egy megoldása van minden rögzített $k \in \mathbb{N}$ és $A>g$ (vagyis $\omega_{h}$ és $\omega_{e}$ ) esetén (lásd az 5.8 ábrát). 
5.5. Következmény. Bármely $A>g$ esetén vannak olyan $\left\{T_{n}\right\}_{n=1}^{\infty}$ és $\left\{\tilde{T}_{n}\right\}_{n=1}^{\infty}$ sorozatok, hogy

$$
0<T_{1}<\tilde{T}_{1}<\tilde{T}_{2}<T_{2}<T_{3}<\cdots \tilde{T}_{n}<\tilde{T}_{n+1}<T_{n+1}<T_{n+2} \cdots
$$

és az (5.2) egyenletnek a $T=T_{n}$ választással $2 T$-periodikus megoldásai, illetve $T=\tilde{T}_{n}$ választással $4 T$-periodikus megoldásai vannak.

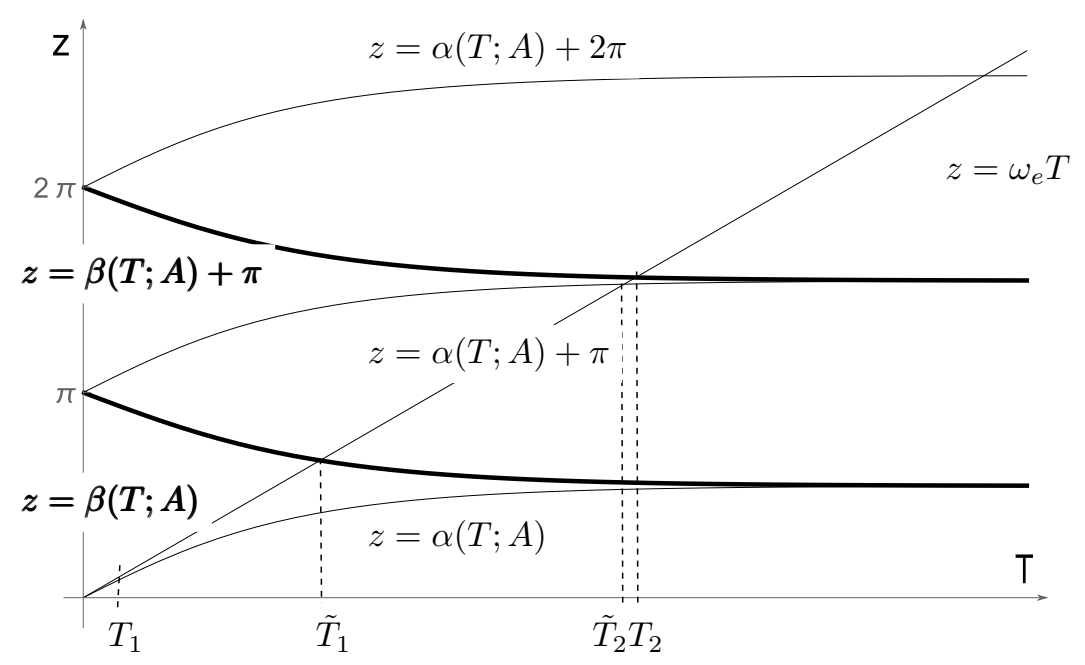

5.8. ábra. Az (5.13)-(5.16) feltételek

\subsection{Stabilitás és számítógépes szimulációk}

A kapott eredményeket fölhasználjuk arra is, hogy a vizsgált - szimmetrikus - modell stabilitási térképét elkészítsük. Amint arról a 3.1 és 3.2 fejezetekben már volt szó a $(T, A)$ paramétersík azon részhalmazait, amelyek pontjai megfelelnek az erôsen stabil egyenleteknek, stabil zónáknak hívjuk. Annak érdekében, hogy a korábbi - becsléseken alapuló - eredményeinket összevethessük a jelen fejezetben megkapottakkal, $T$ és $A$ helyett tekintsük a (4.28) kifejezésben bevezetett $\varepsilon$ és $\mu$ paramétereket. Fölhívjuk a figyelmet, hogy az $\varepsilon$ definíciójában szerepel az amplitúdó, amit ott $D$ jelölt. Ebben a fejezetben viszont $D$ már szerepel $\left(D=\omega_{h} / \omega_{e}\right)$. Ezt elkerülhetjük, ha fölhasználjuk a (4.11) kifejezéseket, értelemszerúen módosítva a szimmetrikus esetnek megfelelôen. Tehát

$$
\varepsilon=\frac{1}{\sqrt{8 l}} T \sqrt{A} \quad(\varepsilon>0), \quad \mu=\frac{\sqrt{g}}{\sqrt{A}} \quad(0<\mu<1) .
$$


Így az 5.3 és 5.4 tételek formuláiban szereplő $\omega_{h} T, \omega_{e} T$, és $D$ paramétereket az $\varepsilon$ és $\mu$ segítségével átírva, melyet a (4.29) kifejezésben már megtettünk, átfogalmazhatjuk az 5.3 tételt.

5.6. Következmény. Az (5.2) egyenletnek akkor és csakis akkor van $2 T$-periodikus megoldása, ha vannak olyan $\varepsilon$ és $\mu$ pozitív konstansok, továbbá van olyan nemnegatív egész $k$, hogy vagy

$$
2 \arctan \left(\sqrt{\frac{1+\mu^{2}}{1-\mu^{2}}} \frac{e^{2 \sqrt{2} \varepsilon \sqrt{1+\mu^{2}}}-1}{e^{2 \sqrt{2} \varepsilon \sqrt{1+\mu^{2}}}+1}\right)+2 k \pi=2 \sqrt{2} \varepsilon \sqrt{1-\mu^{2}},
$$

vagy

$$
2 \arctan \left(\sqrt{\frac{1+\mu^{2}}{1-\mu^{2}}} \frac{e^{2 \sqrt{2} \varepsilon \sqrt{1+\mu^{2}}}+1}{e^{2 \sqrt{2} \varepsilon \sqrt{1+\mu^{2}}}-1}\right)+(2 k+1) \pi=2 \sqrt{2} \varepsilon \sqrt{1-\mu^{2}} .
$$

Hasonlóképpen, az 5.4 tétel is megadható $\varepsilon$ és $\mu$ segítségével.

5.7. Következmény. $A z$ (5.2) egyenletnek akkor és csakis akkor van $4 T$-periodikus, de nem $2 T$-periodikus megoldása, ha vannak olyan $\varepsilon$ és $\mu$ pozitív konstansok, továbbá van olyan nemnegatív egész $k$, hogy vagy

$$
2 \arctan \left(\sqrt{\frac{1+\mu^{2}}{1-\mu^{2}}} \frac{e^{2 \sqrt{2} \varepsilon \sqrt{1+\mu^{2}}}-1}{e^{2 \sqrt{2} \varepsilon \sqrt{1+\mu^{2}}}+1}\right)+(2 k+1) \pi=2 \sqrt{2} \varepsilon \sqrt{1-\mu^{2}}
$$

vagy

$$
2 \arctan \left(\sqrt{\frac{1+\mu^{2}}{1-\mu^{2}}} \frac{e^{2 \sqrt{2} \varepsilon \sqrt{1+\mu^{2}}}+1}{e^{2 \sqrt{2} \varepsilon \sqrt{1+\mu^{2}}}-1}\right)+2 k \pi=2 \sqrt{2} \varepsilon \sqrt{1-\mu^{2}} .
$$

Az 5.6 és 5.7 fölhasználásával az $(\varepsilon, \mu)$ paramétersíkon tudjuk ábrázolni az Arnold-nyelveket. Így például az elsô két nyelvet az 5.9 ábrán láthatjuk.

Azt is láttuk, hogy a stabilitási tartomány $m$-edik komponensének $(m \in \mathbb{N})$ gerincét a (4.31) formulával megadott $G_{m}$ görbe alkotja. Ezen görbék megfelelôjét most a

$$
G_{m}: 2 \sqrt{2} \varepsilon \sqrt{1-\mu^{2}}-2 \arctan \sqrt{\frac{1+\mu^{2}}{1-\mu^{2}}}=m \pi, \quad m \in \mathbb{N}
$$

egyenlettel adott görbék alkotják.

Az 5.10 ábrán $m=0$ esetén láthatjuk a korábbi, becslésen alapuló számításokból kapott stabilitási zónát az ebben a fejezetben számítottal. 


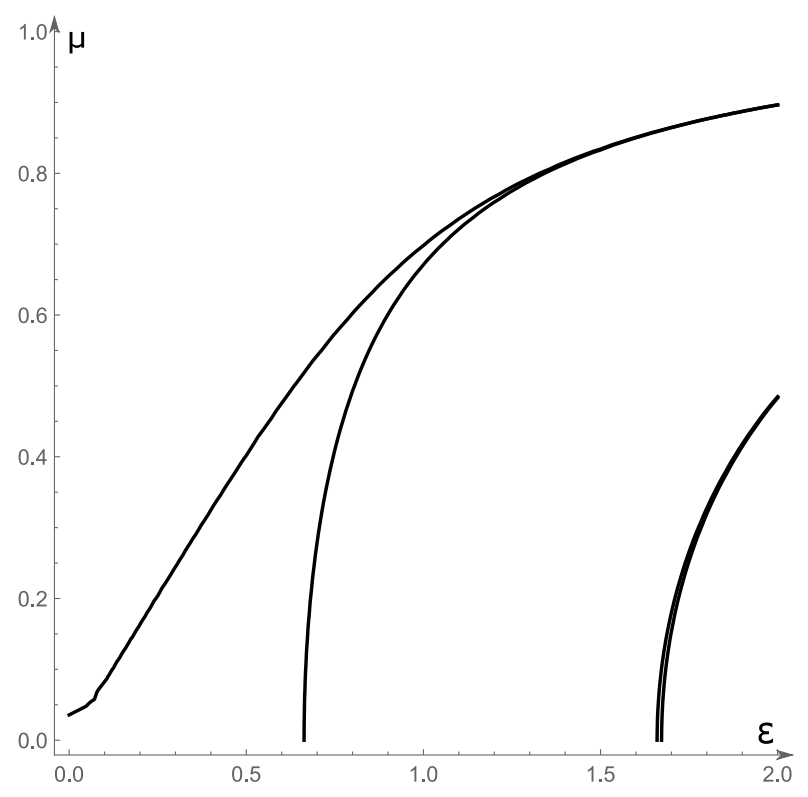

5.9. ábra. Az elsố két stabil zóna

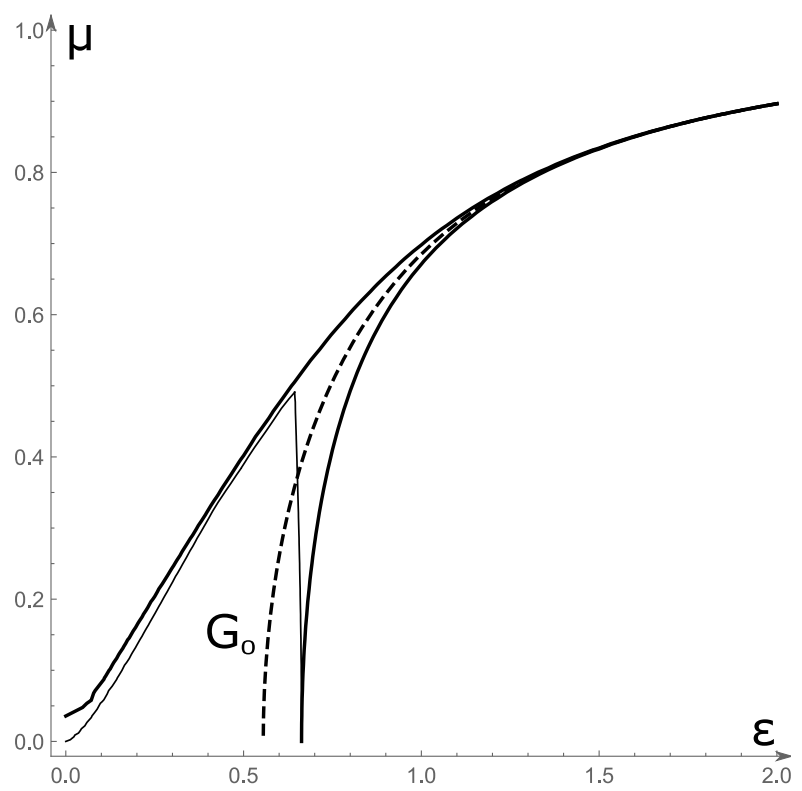

5.10. ábra. A korábban becsléssel kapott és a pontos stabil zóna

A kiszámított periodikus pályák, és a segítségükkel elkészített stabilitási térkép alapján számítógépes szimulációkat készíthetünk. A számítógéppel az 
$\dot{x}=y, \dot{y}=\frac{g+a(t)}{l} x$ differenciálegyenlet-rendszert oldatjuk meg, vagyis az állapothatározók a szögelfordulás és annak idő szerinti deriváltja. Így egyfelől vizualizálhatjuk mindazt, amit kiszámoltunk, másfelól bizonyos mértékig visszaigazolást nyerhetünk számolásunk helyességéról. A Wolfram Research Mathematica 10.4 szoftverét használjuk a számítógépes kísérletezés során. A 5.9 ábrát tekintve és a $\mu=0,2 \Rightarrow A=245,25$ értéket, valamint az $\varepsilon=0,5 \Rightarrow T=2 / 15$ értéket választva nézzük meg mit ad a számítógépes szimuláció, ha a mozgásegyenletet a [0,6/15] intervallumon oldatjuk meg, illetve ábrázoljuk a fázissíkon a trajektóriát, valamint a $t \mapsto x(t)$ függvény grafikonját, tehát az inga rúdjának függólegessel bezárt szögét az idő függvényében. Kezdeti értékekként az $x_{0}=0,1, y_{0}=-0,1$ választva az $l=2$ hosszúságú inga esetén az $5.11,5.12$ ábrákat kapjuk.

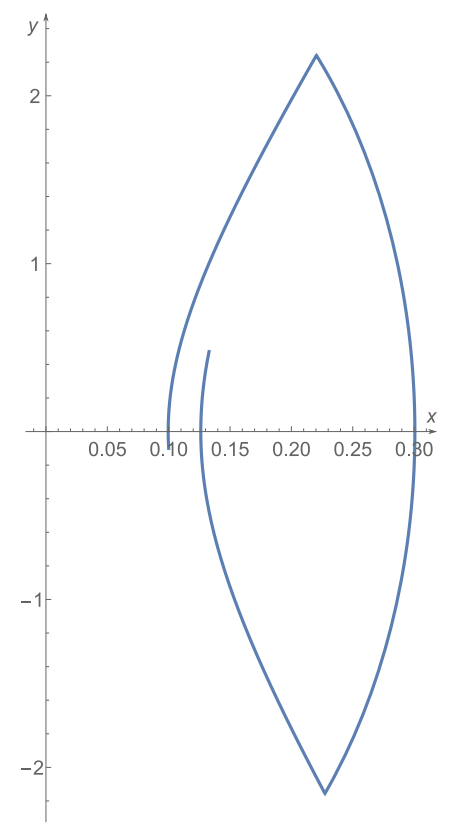

5.11. ábra. A trajektória, ha $t \in[0,6 / 15]$

Ugyanazokkal a paraméterekkel, de a $[0,1]$ intervallumon megoldva az egyenletet, az 5.13 és az 5.14 ábrák alapján is egyre jobban érezhető, hogy a megoldás stabil.

Egy viszonylag hosszú szakaszon $([0,30])$ is nézzük meg a szögkitérést: 5.15 ábra. 


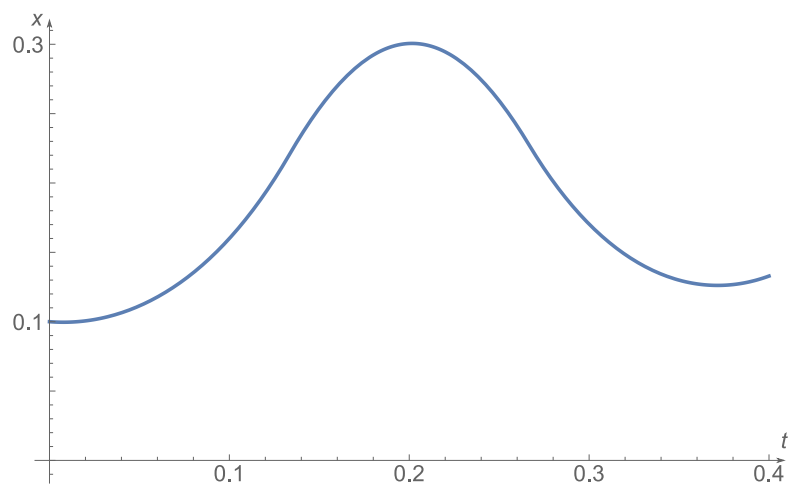

5.12. ábra. Az $x=x(t)$ szögkitérés, ha $t \in[0,6 / 15]$

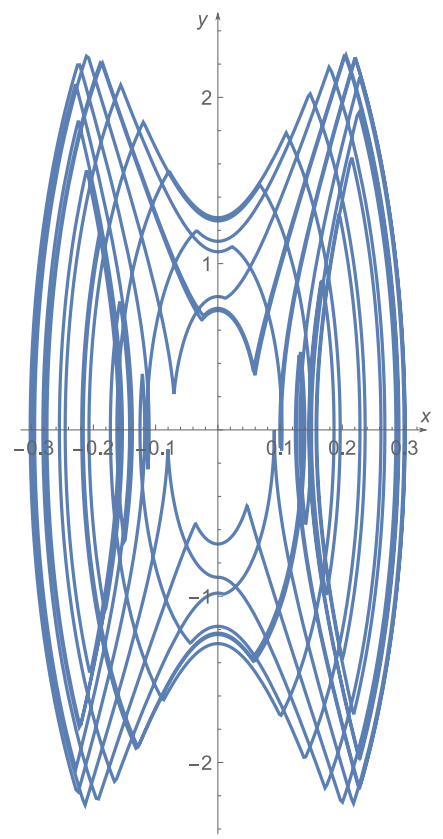

5.13. ábra. A trajektória, ha $t \in[0,1]$

Az 5.15 ábráról is látszódik, hogy a megoldásgörbe a lebegésre emlékeztető hatást jelez. Ez a Floquet-elvnél olvasható gondolatok alapján nem is meglepő: egy $2 T$-periodikus együtthatójú rendszer stabil megoldásairól van szó, vagyis a monodrómia mátrix sajátértékei tisztán képzetesek, így tehát a 3.1 tételben az általános megoldásra adott $\Phi(t)=P(t) e^{t B}$ formula alapján az alaprendszert $r(t) \cos \beta t-s(t) \sin \beta t, r(t) \cos \beta t+s(t) \sin \beta t$ alakú függvények alkotják, ahol $r$ és 


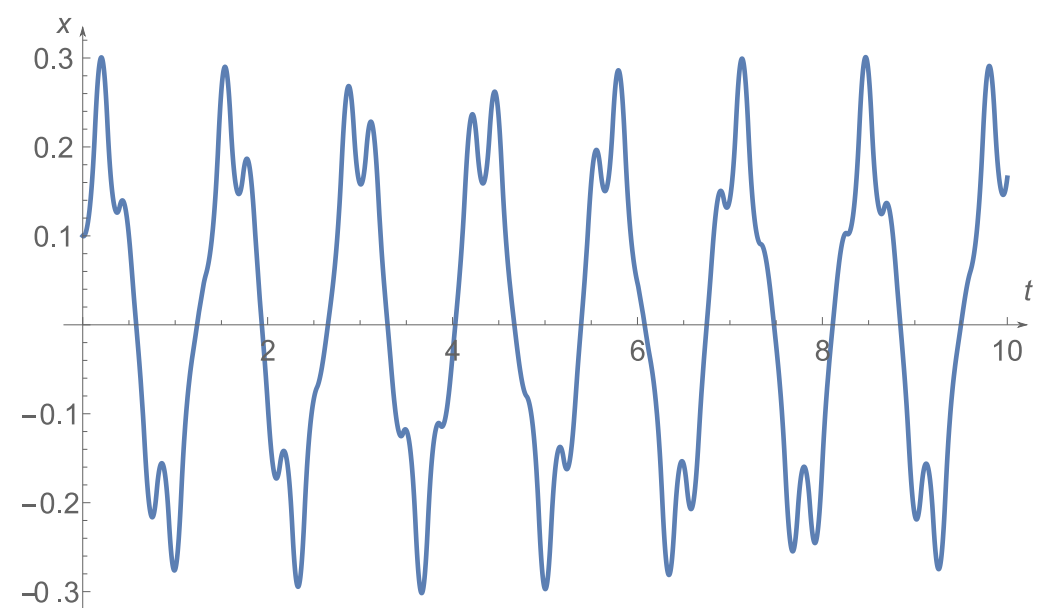

5.14. ábra. Az $x=x(t)$ szögkitérés, ha $t \in[0,1]$

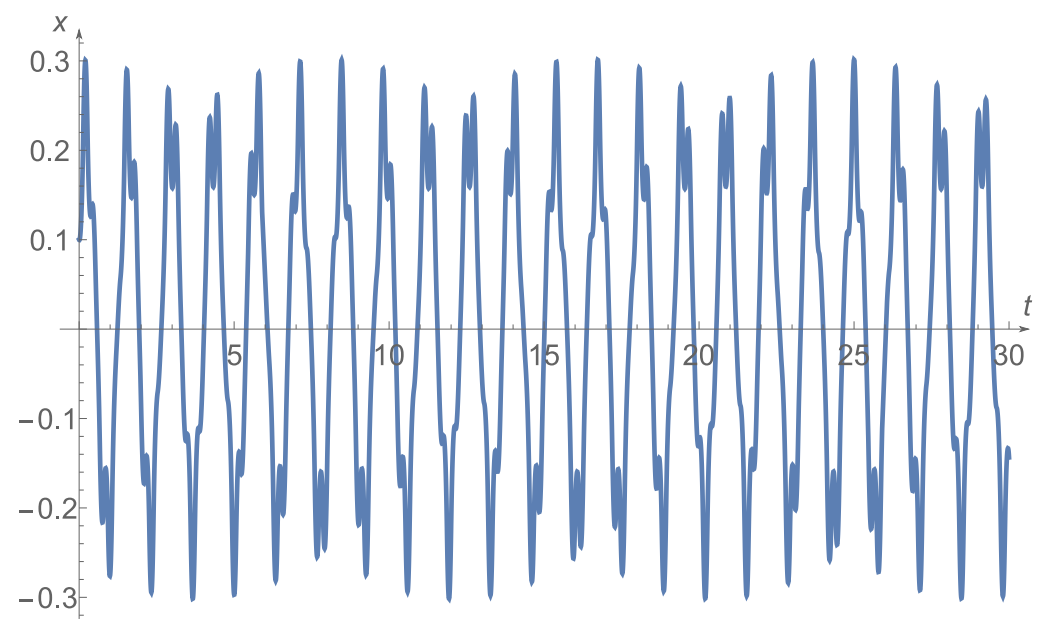

5.15. ábra. Az $x=x(t)$ szögkitérés, ha $t \in[0,30]$

$s$ 2T-periodikus függvények. Ez azt mutatja, hogy az ábrázolt $x=x(t)$ megoldás vagy periodikus (amikor $2 T$ és a $B$ sajátértékének megfelelő periódusidő $(2 \pi / \beta)$ hányadosa racionális) vagy kvázi-periodikus (amikor az említett periódusidôk hányadosa irracionális). Minderrôl részletesen a [8]-ban olvashatunk.

Az 5.15 ábrát látva egyre biztosabbak lehetünk abban, hogy stabilis az egyensúlyi helyzet: $t=30$-ig lefuttatva a számolást, a kitérés az idônek korlátos függvénye. Ha ugyanígy járunk el, de még tovább engedjük a számolást, például $t=100$-ig, akkor az 5.16 ábrán látható grafikont kapjuk. Eléggé meggyôzô. A 


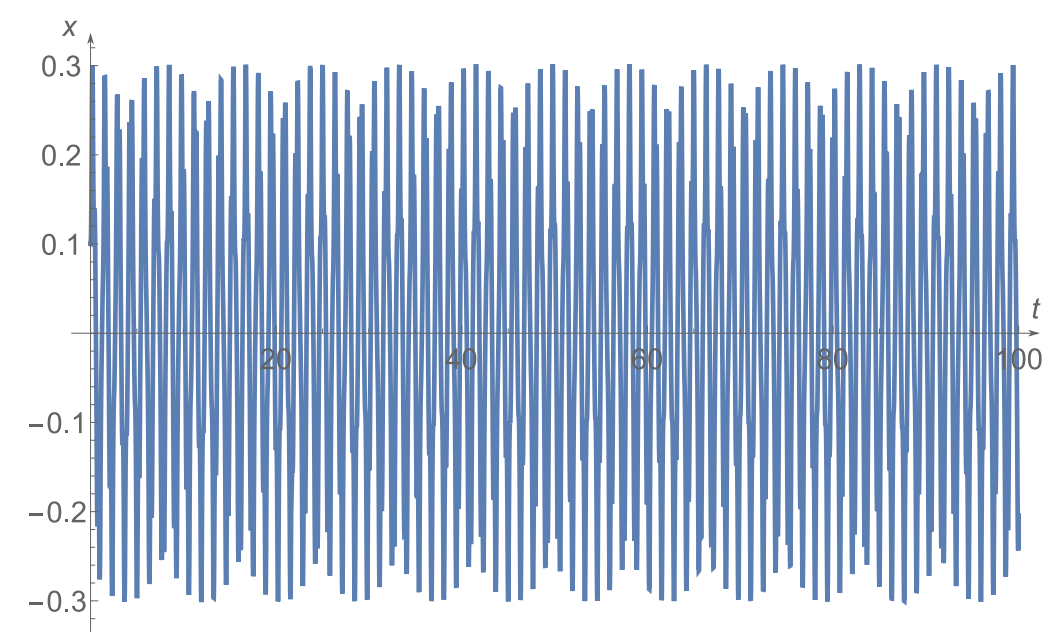

5.16. ábra. Az $x=x(t)$ szögkitérés, ha $t \in[0,100]$

fázissíkon a trajektória is szépen árulkodik: $t=300$-ig számolva, és a fázispont képét ábrázolva az 5.17 grafikont kapjuk. Azt látjuk, hogy egy, az origó körüli korlátos síkrészen mozog a fázispont, ilyen módon jelezve az origó stabilitását.

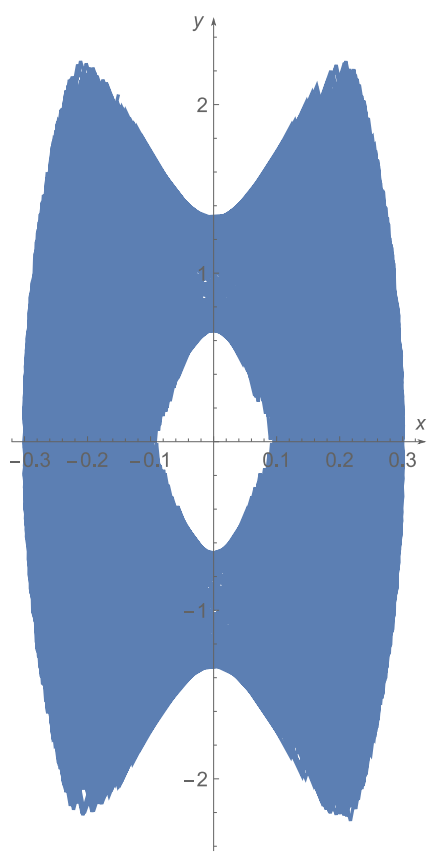

5.17. ábra. A fáziskép, ha $t \in[0,300]$ 
A számítógépes kísérletezés alkalmat ad arra is, hogy az inga eredeti, nemlineáris egyenletét vizsgáljuk. Változatlan paraméterértékek mellett 0-tól 50-ig megoldatva az egyenletet, az 5.18 és az 5.19 ábrát kapjuk. Látszódik, hogy linearizált jól közelíti a nemlineáris kifejezést.

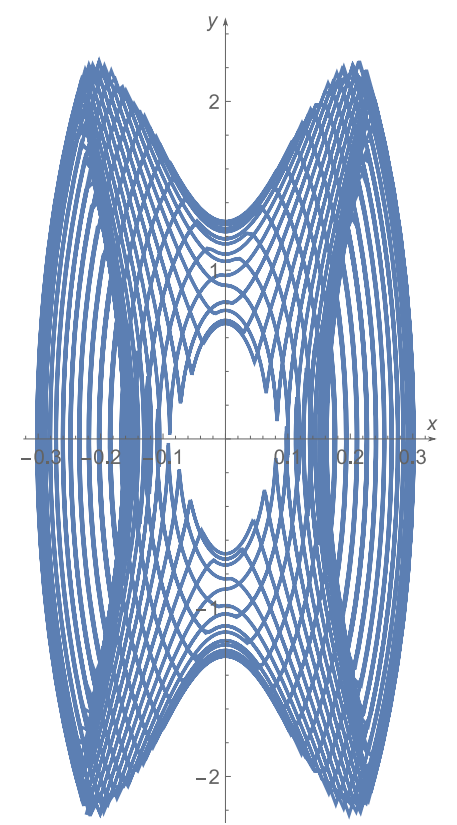

5.18. ábra. Fázisporté nemlineáris esetben, ha $t \in[0,50]$

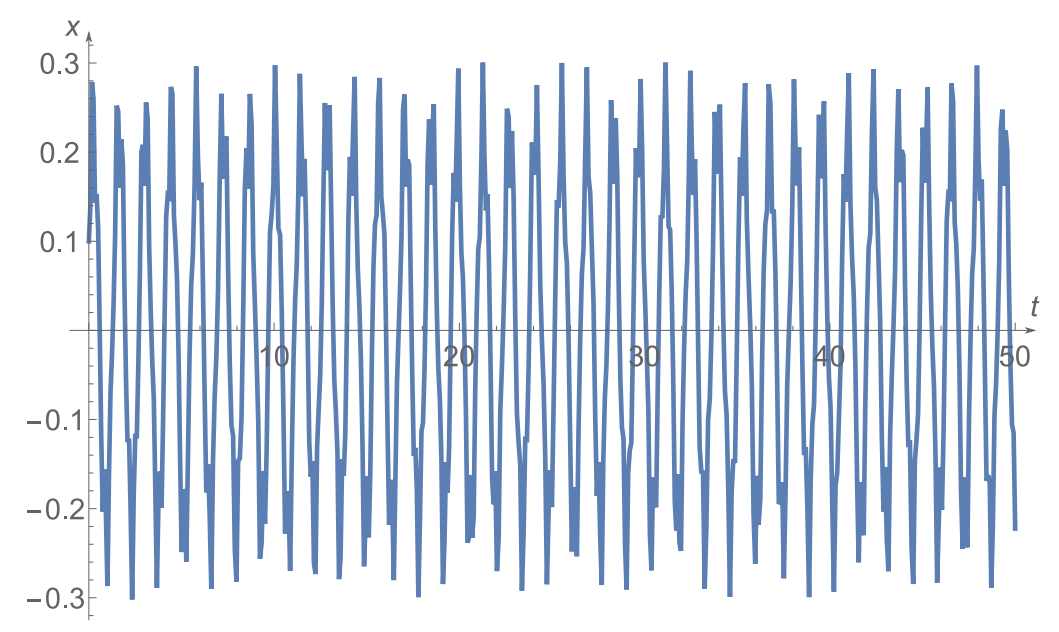

5.19. ábra. Az $x=x(t)$ szögkitérés nemlineáris esetben, ha $t \in[0,50]$ 


\section{6. fejezet}

\section{Összefoglalás}

A disszertációban a gerjesztett inga egyensúlyi helyzetei körüli mozgásokat vizsgálunk, mely gerjesztés lépcsôsfüggvény-együtthatóként jelenik meg a lineáris mozgásegyenletekben. Arra keressük a választ, hogy gerjesztésben meglévô paraméterek mely értékeire várhatjuk az inga alsó egyensúlyi helyzetének instabilitását, illetve a fölső egyensúlyi helyzetének stabilitását. Vizsgálati módszerünket eleminek mondjuk abban az értelemben, hogy kikerüli a periodikus együtthatós differenciálegyenletek klasszikus elméletére, az úgynevezett Floquet-elvre épülő nehezen kezelhetô számításokat, helyette jellemzően egyszerû geometriai megfontolások vezetnek eredményre. Az értekezés az alábbi publikációkon alapul:

- L. Csizmadia, L. Hatvani, An extension of the Levi-Weckesser method to the stabilization of the inverted pendulum under gravity, Meccanica, 49(2014), 1091-1100.

- L. Csizmadia, L. Hatvani, On a linear model of swinging with a periodic step function coefficient, Acta Sci. Math. (Szeged), 81(2015), 483-502.

- L. Csizmadia, L. Hatvani, On the existence of periodic motions of the excited inverted pendulum by elementary methods (benyújtva).

Elsóként a hintázás problémájára adunk egy választ. A hinta egy olyan inga, melynek hossza az időben változik. Az [1] múben leírtak szerint, tegyük föl, hogy 
a hintázó hatására a hinta hossza periodikusan változik, azaz tekintsük az

$$
\begin{aligned}
\ddot{x}+a^{2}(t) x=0, \\
a(t):=\left\{\begin{aligned}
a_{1} & :=\sqrt{\frac{g}{l-\varepsilon}}, \text { ha } \quad 2 k T \leq t<(2 k+1) T, \\
a_{2}: & :=\sqrt{\frac{g}{l+\varepsilon}}, \text { ha } \quad(2 k+1) T \leq t<(2 k+2) T,(k=0,1, \ldots)
\end{aligned}\right.
\end{aligned}
$$

egyenletet, ahol $x$ jelöli az inga rúdjának a függólegessel bezárt szögét, továbbá $\varepsilon>0$ az a paraméter, melynek segítségével a hintázás intenzitását jellemezzük, $T>0, g$ a gravitációs gyorsulás, $l$ pedig az inga hossza. A feladat: határozzuk meg a $(T, \varepsilon)$ paramétersík instabil tartományát, vagyis azon részét, ahonnan választott paraméterértékekkel a (6.1) egyenlet $x=0$ megoldása instabil.

Bevezetve az origóhoz közeledő, illetve origótól távolodó szögperiodikus megoldás fogalmát konstruktív módon tudjuk megadni a hintázó periódusideje $(2 T)$ és a hintázás intenzitása $(\varepsilon)$ függvényében azt a szükséges és elegendő föltételt, mely garantálja a mozgásegyenlet gerjesztési periódussal megegyezô periódusú, illetve a gerjesztési periódus duplájával megegyezô periódusú megoldásainak létezését. Ez utóbbiak pedig kijelölik a $(T, \varepsilon)$ sík instabil tartományát. Meggondolásaink eredményeképpen a következôt írhatjuk.

6.1. Tétel. $A(6.1)$ egyenletre vonatkozó $(T, \varepsilon)$ paramétersík instabil tartományának belseje

$$
\begin{aligned}
& \cup_{0<\varepsilon<l}\left(\cup _ { p = 0 } ^ { \infty } \left(\left\{(T, \varepsilon): T_{2 p+1}(\varepsilon)<T<T_{2 p+2}(\varepsilon)\right\} \cup\right.\right. \\
& \left.\left.\left\{(T, \varepsilon): \widetilde{T}_{2 p+1}(\varepsilon)<T<\widetilde{T}_{2 p+2}(\varepsilon)\right\}\right)\right),
\end{aligned}
$$

ahol $\left\{T_{k}(\varepsilon)\right\}_{k=1}^{\infty}$, illetve $\left\{\widetilde{T}_{k}(\varepsilon)\right\}_{k=1}^{\infty}$ olyan sorozat, hogy a (6.1) egyenletnek a $T=T_{k}(\varepsilon)$ választással $2 T_{k}(\varepsilon)$-periodikus, illetve a $T=\widetilde{T}_{k}(\varepsilon)$ választással $4 \widetilde{T}_{k}(\varepsilon)$ periodikus megoldása van.

Ezt követôen áttérünk az inga fölső egyensúlyi helyzetének stabilizálhatósága kérdésére. Azt a speciális esetet tekintjük, amikor az inga fölfüggesztési pontjára egy függóleges irányú, periodikusan változó erô fejt ki hatást. Amennyiben $\psi$ jelöli a függóleges iránnyal bezárt szöget, úgy a fölsố egyensúlyi helyzet körüli mozgásokat leíró egyenlet a

$$
\ddot{\psi}-\frac{1}{l}(g+a(t)) \psi=0 .
$$


alakú, ahol

$$
a(t):= \begin{cases}A_{h}, \text { ha } & k T \leq t<k T+T_{h}, \\ -A_{e}, \text { ha } & k T+T_{h} \leq t<\left(k T+T_{h}\right)+T_{e}, \\ (k=0,1, \ldots) & \end{cases}
$$

az inga fölfüggesztési pontjára ható erőből származó gyorsulás. Az $A_{h}, A_{e}, T_{h}, T_{e}$ pozitív konstansok $\left(T_{h}+T_{e}=T\right)$, tehát a felfüggesztési pont mozgása $T$ periodikus.

Egy korábban megjelent dolgozatban [28] található ötletes, becslésen alapuló módszert terjesztünk ki arra az esetre, melyben az eredeti nem használható. Így a gerjesztés periódusideje és gyorsulása függvényében egy pontosabb feltételt tudunk adni a stabilizálhatóságra.

6.2. Tétel. Jelölje $\operatorname{Rem}(\varphi ; \pi)$ a $\varphi \in \mathbb{R}$ valós szám osztási maradékát moduló $\pi$ $(0 \leq \operatorname{Rem}(\varphi ; \pi)<\pi)$.

$\mathrm{Ha}$

$$
\begin{aligned}
& 2 \arctan \frac{e^{\omega_{h} T_{h}}-1}{e^{\omega_{h} T_{h}}+1}+4\left|\arctan \sqrt{\frac{\omega_{h}}{\omega_{e}}}-\frac{\pi}{4}\right| \\
& <\min \left\{\operatorname{Rem}\left(\omega_{e} T_{e} ; \pi\right) ; \pi-\operatorname{Rem}\left(\omega_{e} T_{e} ; \pi\right)\right\},
\end{aligned}
$$

akkor a (6.2) egyenlet erốsen stabil, ahol

$$
\omega_{h}:=\sqrt{\frac{A_{h}+g}{l}}, \quad \omega_{e}:=\sqrt{\frac{A_{e}-g}{l}} .
$$

Az erôs stabilitás röviden szólva azt jelenti, hogy a rendszer annak minden kis perturbáltjával együtt stabil. A [28] cikkben a szerző́k módszere csak az $A_{h}=A_{e}$ és a $g=0$ feltételek teljesülése esetén használható. Érthetô az igény ezen feltételek (fóként a második!) elhagyására, amely a 6.2 tételben valósult meg.

Miután a fölsổ egyensúlyi helyzet stabilitását garantáló feltételünk is egy becslés, ezért a gerjesztô lépcsősfüggvény periódusával megegyező, illetve annak kétszeresével megegyezô periódusú periodikus megoldások konstruálásával a teljesen pontos stabilitási tartományokat írjuk le a dolgozat utolsó részében.

Azt az esetet vizsgáljuk, amikor a mozgásegyenlet

$$
\ddot{\psi}-\frac{1}{l}(g+a(t)) \psi=0
$$


alakú, és amelyben

$$
a(t):= \begin{cases}A, \text { ha } & 2 k T \leq t<(2 k+1) T \\ -A, \text { ha } & (2 k+1) T \leq t<(2 k+2) T \\ (k=0,1, \ldots), & \end{cases}
$$

tehát az inga fölfüggesztési pontjára ható erôból származó gyorsulás $2 T$-periodikus és szimmetrikus. Eljárásunk konklúziójaként a következóket állítjuk.

6.3. Tétel. A (6.3) egyenletnek akkor és csakis akkor van $2 T$-periodikus megoldása, ha vannak olyan A és T pozitív konstansok az (6.4) kifejezésben, és van olyan nemnegativ egész $k$, hogy vagy

$$
2 \arctan \left(D \frac{e^{\omega_{h} T}-1}{e^{\omega_{h} T}+1}\right)+2 k \pi=\omega_{e} T
$$

vagy

$$
2 \arctan \left(D \frac{e^{\omega_{h} T}+1}{e^{\omega_{h} T}-1}\right)+(2 k+1) \pi=\omega_{e} T .
$$

6.4. Tétel. A (6.3) egyenletnek akkor és csakis akkor van 4T-periodikus, de nem $2 T$-periodikus megoldása, ha vannak olyan $A$ és $T$ pozitív konstansok az (6.4) kifejezésben, és van olyan nemnegativ egész $k$, hogy vagy

$$
2 \arctan \left(D \frac{e^{\omega_{h} T}-1}{e^{\omega_{h} T}+1}\right)+(2 k+1) \pi=\omega_{e} T,
$$

vagy

$$
2 \arctan \left(D \frac{e^{\omega_{h} T}+1}{e^{\omega_{h} T}-1}\right)+2 k \pi=\omega_{e} T .
$$

A fejezet a stabilitási tartományok megadásával, illetve a differenciálegyenlet megoldásainak számítógépes szimulációi bemutatásával zárul. 


\section{7. fejezet}

\section{Summary}

In the thesis we investigate the motions of an excited pendulum about their equilibria. The excitation means a step-function coeffitient in the equation of motion, namely in a second order linear eqaution which describes the motions around the upper and the lower equilibrium states. We are looking for the values of the parameters in the excitation for which the the upper equilibrium is stable, and the lower one is unstable. Our method is elementary in the sense that instead of difficult calculations of the Floquet Theory - the classical theory of the differential equation with periodic coefficient - simply geometric ideas are applied. The dissertation is based on the following papers of the author:

- L. Csizmadia, L. Hatvani, An extension of the Levi-Weckesser method to the stabilization of the inverted pendulum under gravity, Meccanica, 49(2014), 1091-1100.

- L. Csizmadia, L. Hatvani, On a linear model of swinging with a periodic step function coefficient, Acta Sci. Math. (Szeged), 81(2015), 483-502.

- L. Csizmadia, L. Hatvani, On the existence of periodic motions of the excited inverted pendulum by elementary methods (submitted).

First, we consider the problem of swinging. The swing is a pendulum whose length changes in time. As in [1], we suppose that the length of the pendulum 
changes periodically, so the equation of motion is

$$
\begin{aligned}
\ddot{x}+a^{2}(t) x=0, \\
a(t):=\left\{\begin{aligned}
a_{1}: & =\sqrt{\frac{g}{l-\varepsilon}}, \text { if } \quad 2 k T \leq t<(2 k+1) T, \\
a_{2}: & =\sqrt{\frac{g}{l+\varepsilon}}, \text { if } \quad(2 k+1) T \leq t<(2 k+2) T, \quad(k=0,1, \ldots),
\end{aligned}\right.
\end{aligned}
$$

where $x$ denotes the angle between the rod of the pendulum and the direction downward measured counter-clockwise; $g$ and $l$ are the gravity acceleration and the length of the rod, respectively, $\varepsilon>0$ is a parameter measuring the intensity of swinging. The problem of swinging is to find the instability domain on the parametric plane $(T, \varepsilon)$ to the excited equation (problem of parametric resonance), where the solution $x=0$ of the corresponding equations of motion is unstable.

Introducing the concepts of solutions going away from the origin and approaching to the origin, we give necessary and sufficient conditions in terms of $T$ and $\varepsilon$ for the existence of solutions of these types, which yield conditions for the existence of $2 T$-periodic and $4 T$-periodic solutions as special cases. The domain of instability, i.e., the Arnold tongues of parametric resonance are deduced from these results. As a conclusion, we can write the next statement.

Theorem The inside of the instability domain on the parametric plane $(T, \varepsilon)$ is

$$
\begin{aligned}
& \cup_{0<\varepsilon<l}\left(\cup _ { p = 0 } ^ { \infty } \left(\left\{(T, \varepsilon): T_{2 p+1}(\varepsilon)<T<T_{2 p+2}(\varepsilon)\right\} \cup\right.\right. \\
& \left.\left.\left\{(T, \varepsilon): \widetilde{T}_{2 p+1}(\varepsilon)<T<\widetilde{T}_{2 p+2}(\varepsilon)\right\}\right)\right)
\end{aligned}
$$

where $\left\{T_{k}(\varepsilon)\right\}_{k=1}^{\infty}$, and $\left\{\widetilde{T}_{k}(\varepsilon)\right\}_{k=1}^{\infty}$ sequences such that if $T=T_{k}(\varepsilon)$ then the equation of motion has $2 T_{k}(\varepsilon)$-periodic, and if $T=\widetilde{T}_{k}(\varepsilon)$ the equation of motion has $4 \widetilde{T}_{k}(\varepsilon)$-periodic solution.

In the next chapter we study the stability of the upper equilibrium of the pendulum. We consider the suspension point of the pendulum which is vibrating vertically with $T$-periodic acceleration and thus the equation of motion of the pendulum is

$$
\ddot{\psi}-\frac{1}{l}(g+a(t)) \psi=0,
$$


where

$$
a(t):= \begin{cases}A_{h}, \text { if } & k T \leq t<k T+T_{h}, \\ -A_{e}, \text { if } & k T+T_{h} \leq t<\left(k T+T_{h}\right)+T_{e}, \\ (k=0,1, \ldots) & \end{cases}
$$

is $T$-periodic acceleration; $A_{h}, A_{e}, T_{h}, T_{e}$ are positive constants $\left(T_{h}+T_{e}=T\right)$; $\psi$ denotes the angle between the rod of the pendulum and the direction upward measured clockwise.

M. Levi and W. Weckesser [28] gave a simple geometrical explanation for the stability effect provided that the frequency is so high that the gravity can be neglected, and the two half-periods of the periodic excitation of the parameter are symmetric. They obtained also a lower estimate for the frequency in this gravity-free case. In its original form, the Levi-Weckesser method does not work in the case when there acts gravitation, so it is a very natural challenge to find an extension of the method to this more natural case. We extend the Levi-Weckesser method to the arbitrary inverted pendulum not assuming even symmetricity between the upward and downward phases in the vibration of the suspension point. Meanwhile we can improve the method and give a sharper estimate for the frequency in the gravity-free case, too. The main result of the chapter is

Theorem. Let $\operatorname{Rem}(\varphi ; \pi)$ denote the reminder of the real number $\varphi \in \mathbb{R}$ modulo $\pi(0 \leq \operatorname{Rem}(\varphi ; \pi)<\pi)$.

If

$$
\begin{aligned}
& 2 \arctan \frac{e^{\omega_{h} T_{h}}-1}{e^{\omega_{h} T_{h}}+1}+4\left|\arctan \sqrt{\frac{\omega_{h}}{\omega_{e}}}-\frac{\pi}{4}\right| \\
& <\min \left\{\operatorname{Rem}\left(\omega_{e} T_{e} ; \pi\right) ; \pi-\operatorname{Rem}\left(\omega_{e} T_{e} ; \pi\right)\right\},
\end{aligned}
$$

then the equation of motion is strongly stable where,

$$
\omega_{h}:=\sqrt{\frac{A_{h}+g}{l}}, \quad \omega_{e}:=\sqrt{\frac{A_{e}-g}{l}} .
$$

The equation is called strongly stable if it is stable together with all of its sufficiently small perturbations.

The previous result about the stability of the upper equilibirum is an estimation. In Chapter 5 we give the exact stability zones with the help of periodic solutions whose periods equal either the period of exitation or the double of it. 
We consider the equation of motion

$$
\ddot{\psi}-\frac{1}{l}(g+a(t)) \psi=0
$$

where

$$
a(t):= \begin{cases}A, \text { if } & 2 k T \leq t<(2 k+1) T, \\ -A, \text { if } & (2 k+1) T \leq t<(2 k+2) T, \\ (k=0,1, \ldots), & \end{cases}
$$

so the acceleration of the suspension point of the pendulum is periodic with period $2 T$. As conclusions we can state the following theorems.

Theorem There is a solution of the equation of motion of period $2 T$ if and only if there are positive constants $A$ and $T$ and a non-negative integer $k$ such that either

$$
2 \arctan \left(D \frac{e^{\omega_{h} T}-1}{e^{\omega_{h} T}+1}\right)+2 k \pi=\omega_{e} T
$$

or

$$
2 \arctan \left(D \frac{e^{\omega_{h} T}+1}{e^{\omega_{h} T}-1}\right)+(2 k+1) \pi=\omega_{e} T
$$

Theorem There is such a 4T-periodic solution of the equation of motoin which is not $2 T$-periodic if and only if there are positive constants $A$ and $T$ and $a$ non-negative integer $k$ such that either

$$
2 \arctan \left(D \frac{e^{\omega_{h} T}-1}{e^{\omega_{h} T}+1}\right)+(2 k+1) \pi=\omega_{e} T,
$$

or

$$
2 \arctan \left(D \frac{e^{\omega_{h} T}+1}{e^{\omega_{h} T}-1}\right)+2 k \pi=\omega_{e} T .
$$

Concluding the chapter we describe the stability zones and present some computer simulations which demonstrate our previous calculations. 


\section{Köszönetnyilvánítás}

Köszönettel tartozom témavezetômnek, Dr. Hatvani László professzor úrnak, aki értékes tanácsaival és javaslataival a disszertáció elkészítésén túl, gyakran egész pályafutásomra vonatkozóan nyújtott segítséget. Megtisztelő, hogy tanítványának mondhatom magam.

Köszönetemet fejezem ki Dr. Vajda Róbert adjunktus úrnak, kedves kollégámnak, aki a Mathematica program használata során előforduló kellemetlenségek esetében sokszor segített megnyugtató választ találni.

Köszönöm a Szegedi Tudományegyetem Bolyai Intézete által nyújtott erkölcsi és infrastrukturális támogatást, mely hozzásegített eddigi eredményeim eléréséhez. 


\section{Irodalomjegyzék}

[1] V. I. Arnold, Ordinary Differential Equations, Springer-Verlag, Berlin, 2006.

[2] D. J. Acheson, T. Mullin, Upside-down pendulums, Nature, 366(2004), $215-216$.

[3] J. Barrow, 100 alapvetố dolog a matematikáról és a múvészetról, amiról nem tudtuk, hogy nem tudjuk, Akkord Kiadó Kft, 2015.

[4] J. A. Blackburn, H. J. T. Smith and N. Gronbeck-Jensen, Stability and Hopf bifurcation in an inverted pendulum, Amer. J. Physics, 60(1992), 903-908.

[5] H. Broer, M. Levi, Geometrical aspects of stability theory for Hill's equations, Arch. Rational Mech. Anal., 131(1995), 225-240.

[6] H. Broer, C. Simo, Resonance Tongues in Hill's Equations; A Geometric Approach, J. Differential Equations, 166(2000), 290-327.

[7] E. Butikov, An improved criterion for Kapitza's pendulum, J. Phys. A: Math. Theor., 44(2011), 1-16.

[8] C. Chicone, Ordinary Differential Equations with Applications, SpringerVerlag, New York, 1999.

[9] L. Csizmadia, L. Hatvani, An extension of the Levi-Weckesser method to the stabilization of the inverted pendulum under gravity, Meccanica, 49(2014), 1091-1100.

[10] L. Csizmadia, L. Hatvani, On a linear model of swinging with a periodic step function coefficient, Acta Sci. Math. (Szeged), 81(2015), 483-502. 
[11] L. Csizmadia, L. Hatvani, On the existence of periodic motions of the excited inverted pendulum by elementary methods (benyújtva).

[12] S. Csörgő, L. Hatvani, Stability properties of solutions of linear second order differential equations with random coefficients, J. Differential Equations, 248(2010), no. 1, 21-49.

[13] A. M. Formal'skii, On the stabilization of an inverted pendulum with a fixed or moving suspension point, Dokl. Akad. Nauk, 406(2006), no. 2, $175-179$.

[14] J. Hale, Ordinary Differential Equations, Wiley-Interscience, New York, 1969.

[15] P. Hartman, Ordinary Differential Equations, Birkhäuser, Boston, 2nd edn., 1982.

[16] L. Hatvani, On the existence of a small solution to linear second order differential equations with step function coefficients, Dynam. Contin. Discrete Impuls. Systems, 4(1998), 321-330.

[17] L. Hatvani, An elementary method for the study of Meissner's equation and its application to proving the Oscillation Theorem, Acta Sci. Math. , 79(2013), no. 1-2, 87-105.

[18] L. Hatvani, On the parametrically excited pendulum equation with a square wave coefficient, Internat. J. Non-Linear Mech., 77(2015), 172-182.

[19] L. Hatvani, On small solutions of second order linear differential equations with non-monotonous random coefficients, Acta Sci. Math. (Szeged), 68(2002), 705-725.

[20] L. Hatvani, L. Stachó, On small solutions of second order differential equations with random coefficients, Arch. Math. (Brno), Equadiff 9 (Brno, 1997), 34(1998), 119-126.

[21] G. W. Hill, On the part of the motion of the lunar perigee which is a function of the mean motions of the sun and moon, Acta Mathematica, 12(1886), Vol. 8, 1-36. 
[22] H. Hochstadt, A special Hill's equation with discontinuous coefficients, Amer. Math. Monthly, 70(1963), 18-26.

[23] P. L. Kapitsa, Dynamical stability of a pendulum when its point of suspension viberates, Zh. Eksper. Teoret. Fiz., 21(1951) (Russian)

[24] P. L. Kapitsa, Pendulum with a vibrating suspension, Uspekhi Fiz. Nauk, 44(1951) (Russian)

[25] L. D. Landau, E. M. Lifshitz, Mechanics, Course of Theoretical Physics, Vol. 1, Elsevier, Amsterdam, 1976.

[26] M. Levi, Stability of the inverted pendulum - a topological explanation, SIAM Rev., 30(1988), 639-644.

[27] M. Levi, Geometry of Kapitsa' potentials, Nonlinearity, 11(1998), 13651368.

[28] M. Levi, W. Weckesser, Stabilization of the inverted, linearized pendulum by high frequency vibrations, SIAM Rev., 37(1995), 219-223.

[29] W. Magnus, S. Winkler, Hill's equation, Dover Publications, Inc., New York, 1979.

[30] J. Meixner, F.W. Schäfke, Mathieusche Funktionen und Sphäroidfunktionen, Springer, 1954.

[31] E. Meissner, Über Schüttel-schwingungen in Systemen mit Periodisch Veränderlicher Elastizität, Schweizer Bauzeitung, 72(1918), no. 10, 9598.

[32] D. R. Merkin, Introduction to the Theory of Stability, Springer-Verlag, 1997.

[33] A. A. Seyranian and A. P. Seyranian, The stability of an inverted pendulum with a vibrating suspension point, J. Appl. Math. Mech., 70(2006), $754-761$.

[34] A. Stephenson, On an induced stability, Phil. Mag., Vol. 15. 6(1908), 233236. 
[35] A. Stephenson, On a new type of dynamical stability, Manchester Memoirs, 52(1908), 1-10.

[36] G. Stépán, Mikrokáosz, Természet Világa, 135(2004), 60-64.

[37] B. Van der Pol, M.J. O. Strutt, On the stability of the solutions of Mathieu's equation, The London, Edinburgh and Dublin Phil. Mag., 7th Series 5(1928), 18-38. 